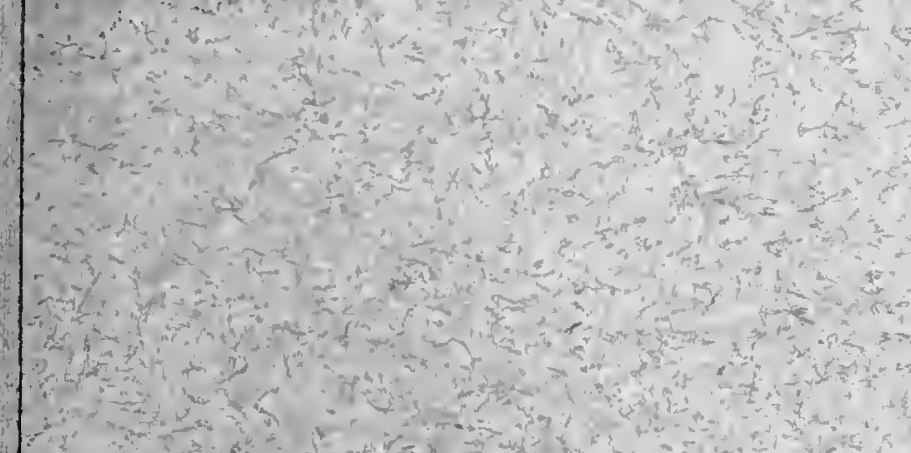

anta

I

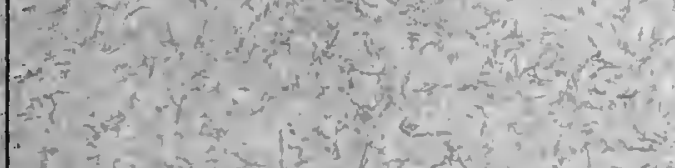

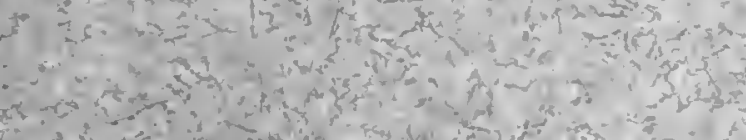

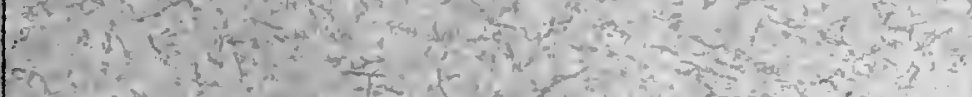

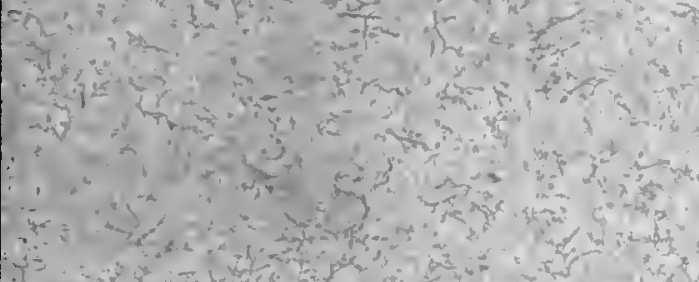

$x+2 y=2$

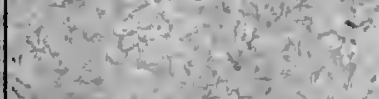




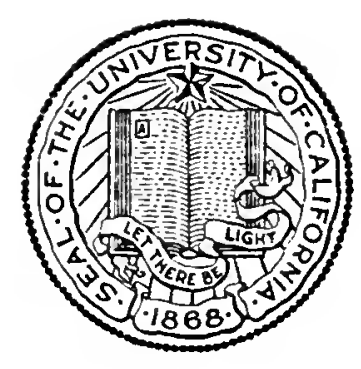

\section{BANCROFT LIBRARY \\ $\diamond$}

THE LIBRARY

OF

\section{THE UNIVERSITY OF CALIFORNIA}

WALTER WADSWORTH BRADLEY

$$
1878-1950
$$

Walter W. Bradley was born in San José and received the degrees of B.S. and E.M. from the University of California. From 1912 to 1946 he was associated with the California Division of Mines, serving as State Mineralogist for the last eighteen years of that period. His published works relate to mining, processing, and geology. This book is from his private collection, presented to the Bancroft Library by Mrs. Alice Roberts Bradley. 


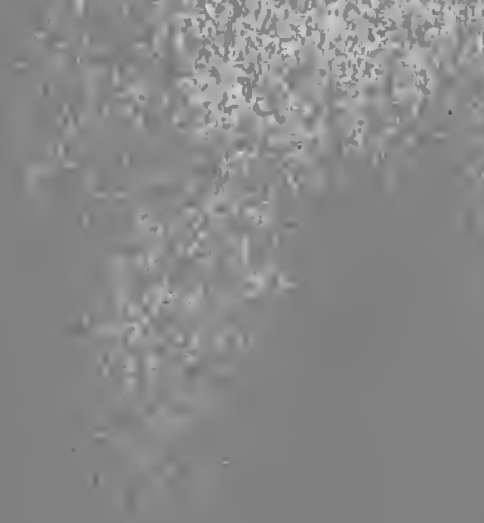




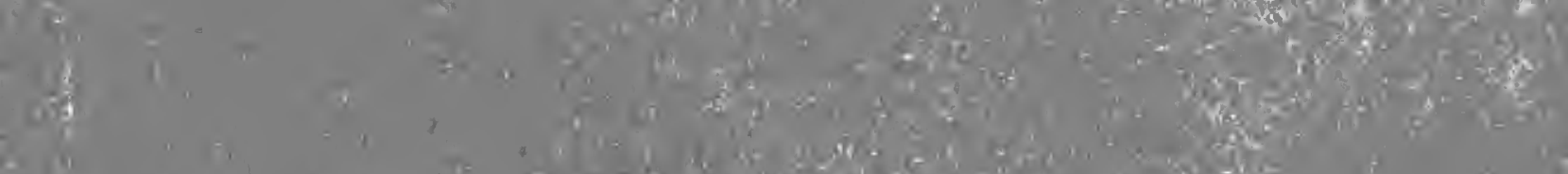

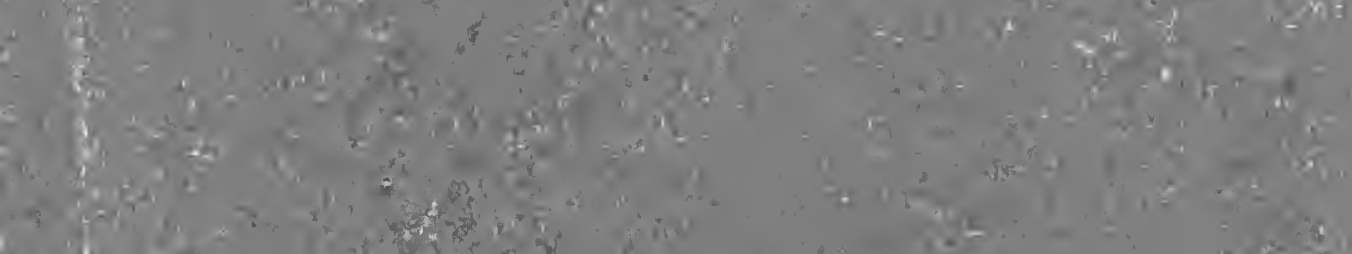

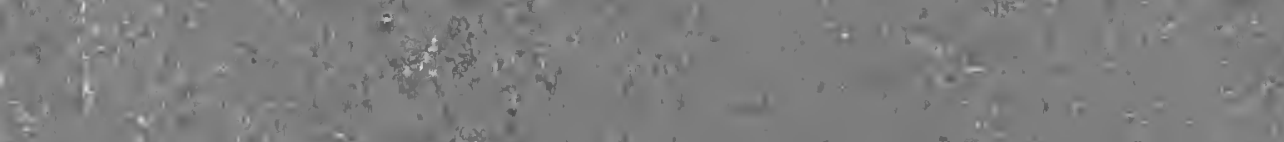

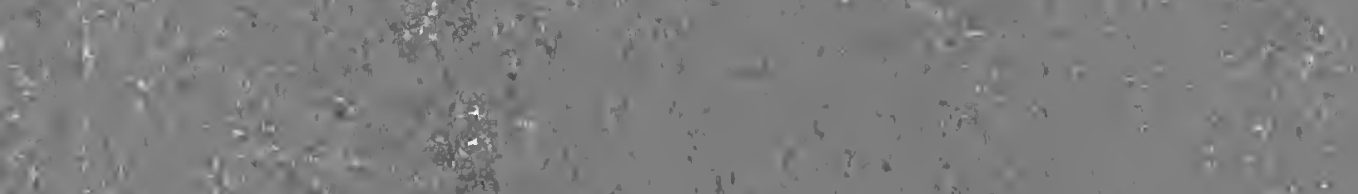

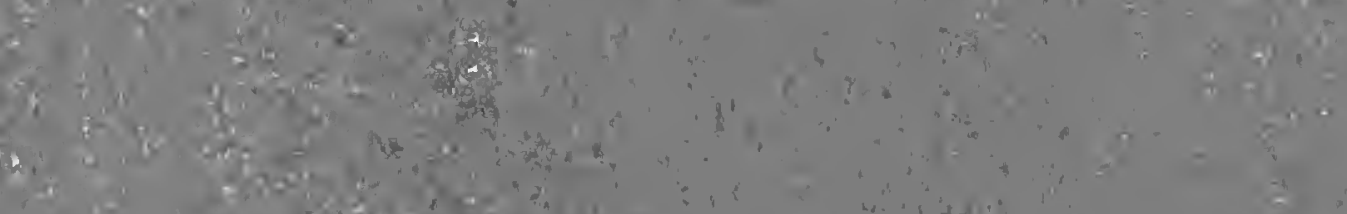

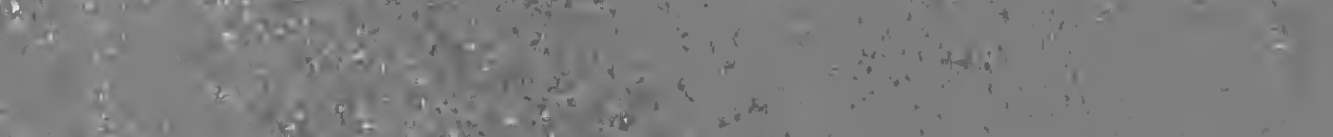

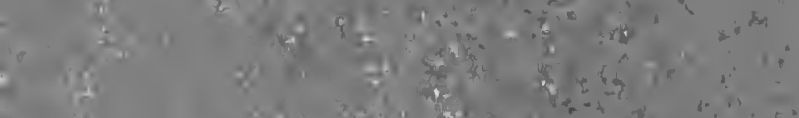

(2)

$\log x+4$

(2. $x+y^{2}+y^{2}=$

i. $x+3 x$

and

(1)

atio

int

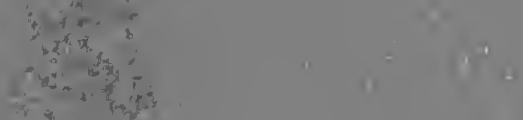

and

$\sin (x)+2$

40

$3 \therefore \sin 3$

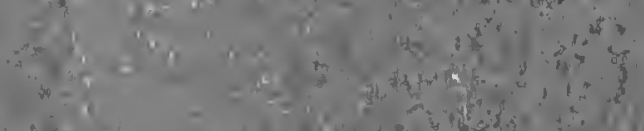

40

0
-6

3
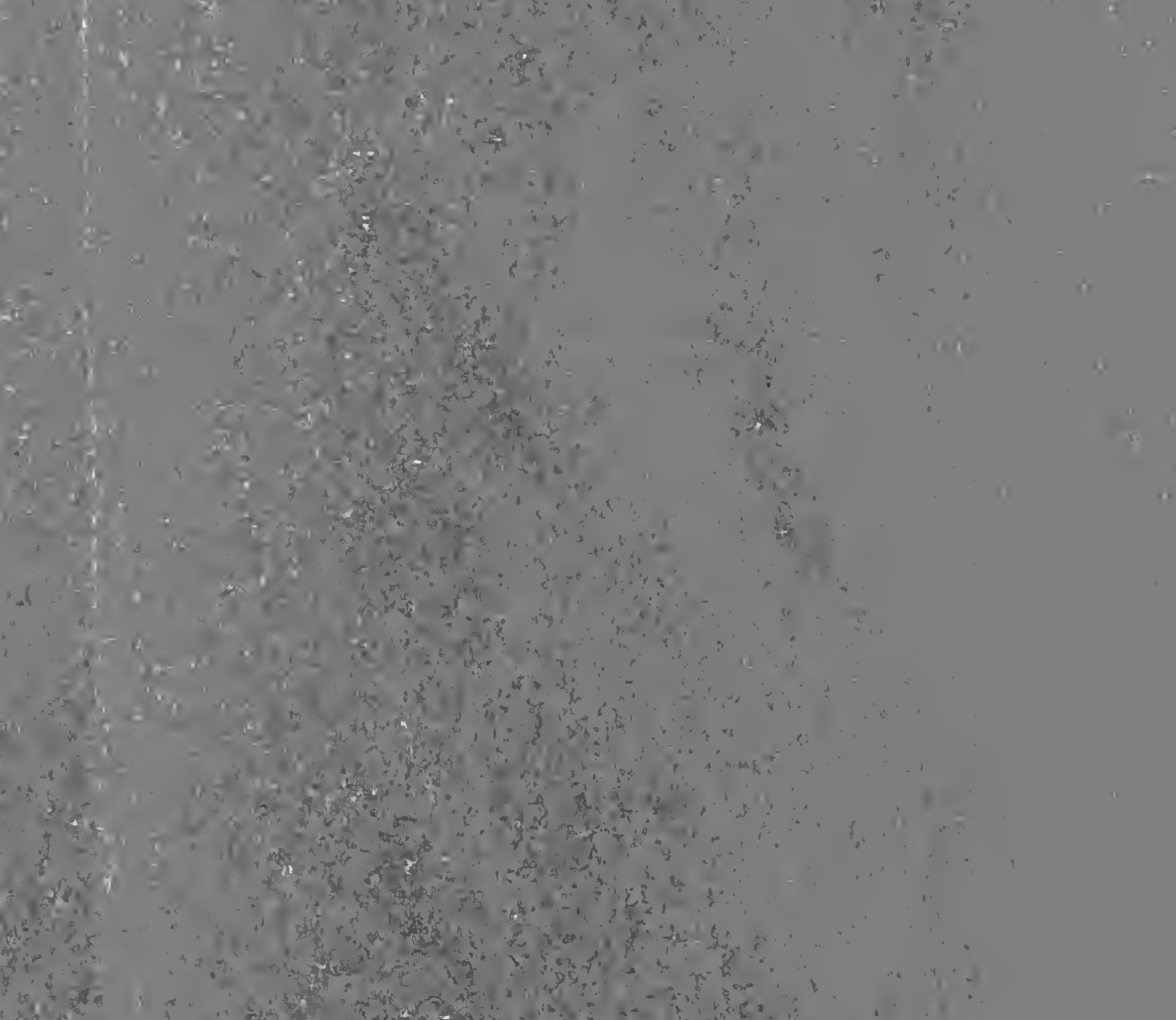

Fon

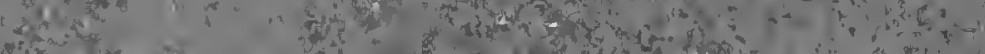




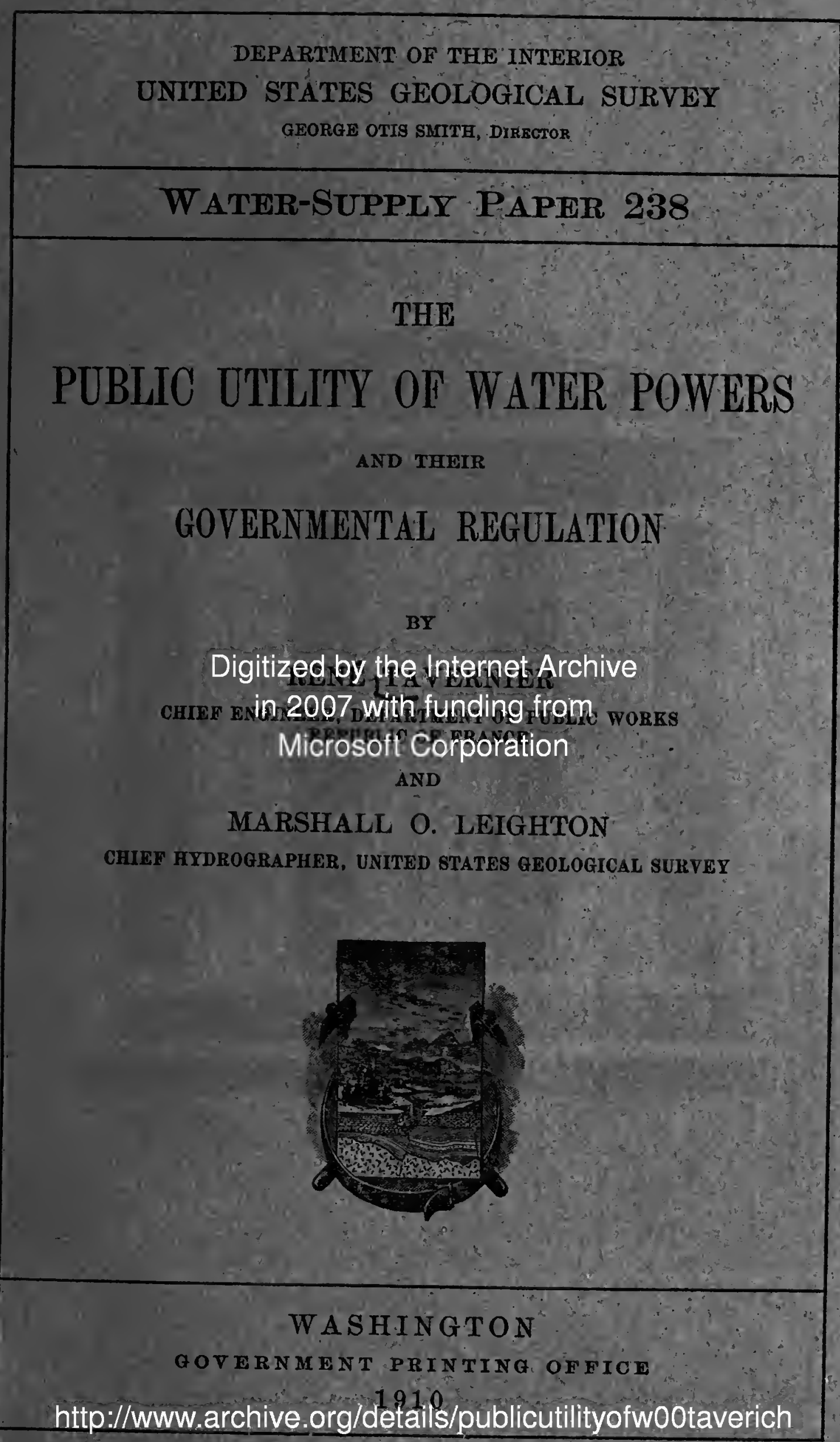



DEPARTMENT OF THE INTERIOR

UNITED STATES GEOLOGICAL SURVEY

GEORGE OTIS SMITH, DIRECTOR

Water-Supply Paper 238

THE

PUBLIC UTILITY OF WATER POWERS

AND 'THEIR

GOVERNMENTAL REGULATION

\author{
BY \\ RENE TAVERNIER \\ CHIEF ENGINEER, DEPARTMENT OF PUBLIC WORKS
} REPUBLIC OF FRANCE

AND

MARSHALL O. LEIGIITON

CHIEF HYDROGRAPHER, UNITED STATES GEOLOGICAL SURVEY

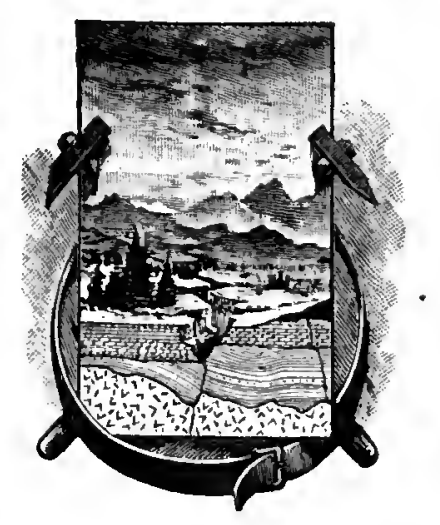

WASHINGTON

GOVERNMENT PRINTING OFFICE

1910 
HD 1694

A4

1910 


\section{CONTENTS.}

Chapter I. Introduction, by M. O. Leighton................. Page.

Chapter II. Hydraulic power and irrigation, by René Tavernier.......... ${ }^{12}$

General statement. ..................................... 12

Influence of industrial utilization of hydraulic power on development of irrigation.

French irrigation methods.

Economic nature of business enterprises employing hydraulic power. . 16

Use of hydraulic plants in the development of irrigation........... 22

Measures adopted by ministry of agriculture to harmonize development of

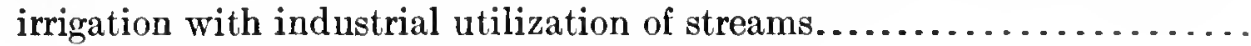

Burcan for investigation of hydraulic power . . . . . . . . . . . . . . .

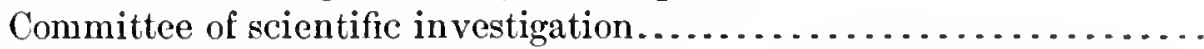

Laws and regulations for reforming system of licenses and permits for hydraulic power plants.

Special studies made by minister of agriculture.................

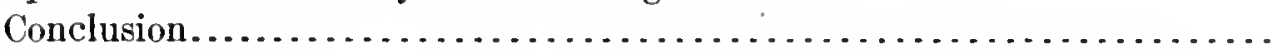

Chapter III. French and foreign legislation relative to the development of water powers, by René Tavernier.

Practical utility of the study . . . . . . . . . . . . . . . . . . . . . . .

French legislation. . . . . . . . . . . . . . . . . . . . . . . . . . .

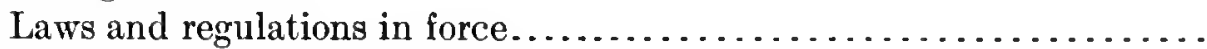

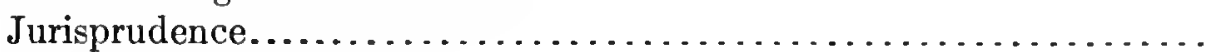

Defects of the present law . . . . . . . . . . . . . . . . . . . . . .

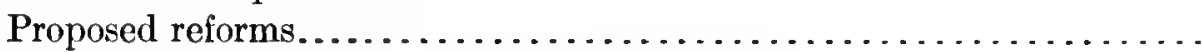

Principles proposed for basis of new legislation. . . . . . . . . . .

Italian legislation . . . . . . . . . . . . . . . . . . . . . . . . . . . . .

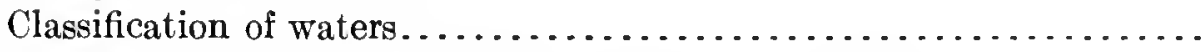

Distinction between "concession" and "authorization" ...........

Analysis of the law of August 10, 1884....................

Public administrative regulation of November $26,1893 \ldots \ldots \ldots \ldots$.

Circular of June 17, 1898 .

Revision of the law of August 10, 1884..................... 48

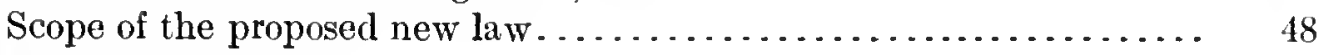

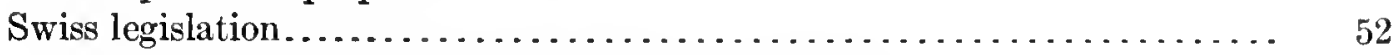

Inquiry into expediency of water-power reforms............. 53

Reforms recommended by federal authorities............... 54

Difficulties involved in electric traction of railroads. . . . . . . . . 55

Water-power concessions in Canton of Berne................. 56

Flexibility in cantonal laws. ............................ 58

Variation in legislative tendency of the Cantons................ 59

Supplementary note, by M. O. Leighton.................... 59 
Chapter III. French and foreign legislation relative to the development of Page. water powers, by René Tavernier-Continued.

Proposed law for the regulation of public water-power plants ............

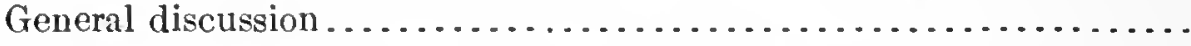

Distinction between private and public plants................

Uniformity in regulations for navigable and nonnavigable streams...

Character of concession . . . . . . . . . . . . . . . . . . . . . . . . . .

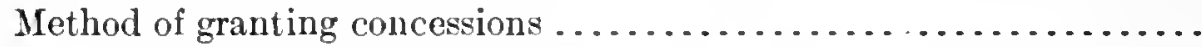

Relations with third parties-damages-easements-expropriations...

Termination of concession . . . . . . . . . . . . . . . . . . . . . .

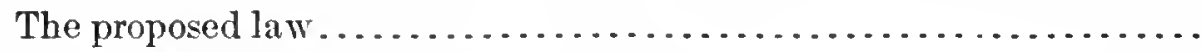

Chapter IV. Laws proposed in the French Parliament..................

Law proposed by M. Albert Lebrun for regulating hydraulic plants on nonnavigable watercourses.

Legislation now in force.

Review of proposed legislation for private power plants..........

The proposed law.

Law proposed by Messrs. Baudin and Millerand for regulation of hydraulic power plants on watercourses and canals of the public domain.......

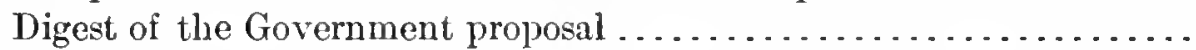

Criticism and justification of the newly proposed law .............

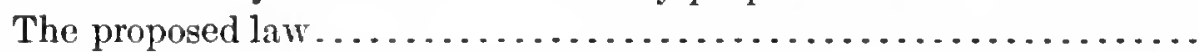

Chapter V. Review of work of bureau of hydraulics and agricultural improve-

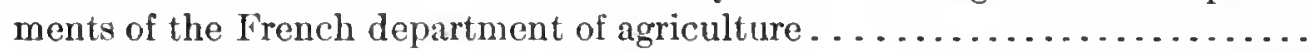

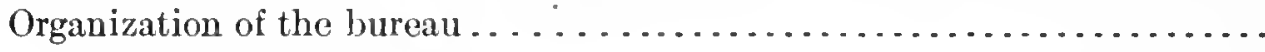

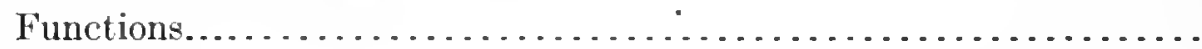

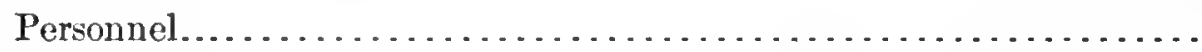

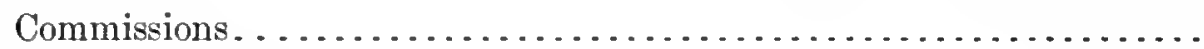

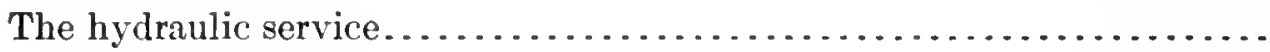

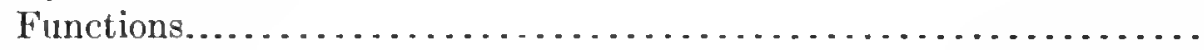

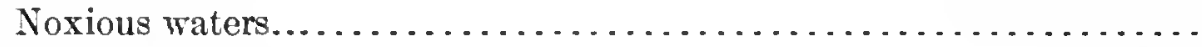

Useful waters ...................................... 100

Agricultural improvement service. . . . . . . . . . . . . . . . . 102

Agricultural utilization of waters. . . . . . . . . . . . . . . . 103

Drainage and soil improvement....................... 103

Redistribution, farm roads, remaking the cadaster............ 104

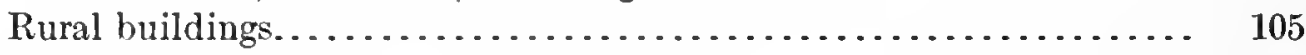

Improvement of poor or uncultivated land............... 106

Miscellaneous improvements............................ 106

Meteorology .................................... 107

Chapter VI. Water-power legislation in the United States, by M. O. Leighton. 108

Federal statutes and powers............................... 108

Effect of the desert-land act........................... 108

Water powers on navigable streams...................... 123

Government dams on navigable streams................... 136

Water powers on the public lands....................... 137

Forest Service regulations................................ 139

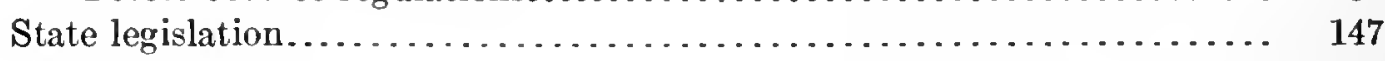

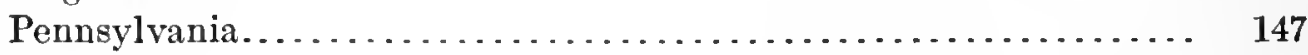

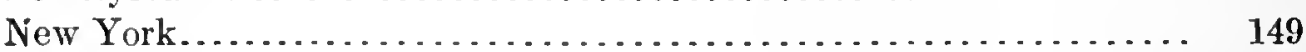

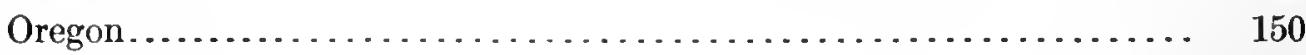

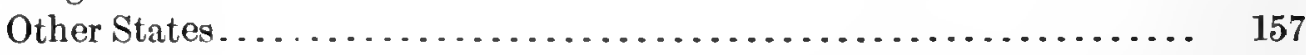

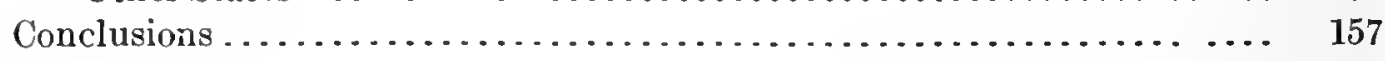

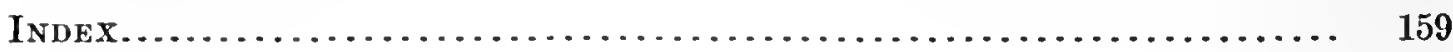




\title{
THE PUBLIC UTILITY OF WATER POWERS AND THEIR GOVERNMENTAL REGULATION.
}

\author{
CHAPTER I. \\ INTRODUCTION.
}

By M. O. Lingititon.

This paper is published to show how the French and the Swiss Republics and the Kingdom of Italy are treating a grave problem in their political economy-the problem of water power. The people of the United States are facing the sane problem, although, except in a few notable localities, they have not begun to apply any method of serious treatment. The problem has grown well-nigh to maturity within ten years, and few have been aware. Had the country foreseen what has come to pass its treatment would have been easy. In its early years the issue might have been easily guided; now it will dominate a great controversy. The final result is not in question, but in the contest that must take place it will be wise to observe the nature and the drift of measures adopted by older countries and to learn all that may be helpful of their methods and acts. In this contest the following paper by M. René Tavernier, the distinguished chief engineer of the department of public works (ponts et chaussées) of the Republic of France, must be of value to the Ameriean people. As the delegate of his country to the Sixteenth National Irrigation Congress, convened at Albuquerque, N. Mex., in Augnst, 1908, he presented a discussion of the subject of hydraulic power and irrigation which revealed so broad a conception of fundamental principles, and especially of the relation of the subject to national economy, that he was urged to increase the scope of his discussion to cover the subjectmatter herein.

One of the striking features of the French discussion here and elsewhere is the apparent appreciation by all who have participated in public discussion of the fact that the problem has two sides. Corporate abuses-past, present, and prospective-are recognized, and 
the need for remedial legislation is practically undisputed. On the other hand, it is admitted, even by the most zealous advocate of governmental intervention, that correction does not mean repression. Hydro-electric properties have not, as a class, returned to the investor a succession of swollen dividends. The industry has hardly passed its experimental stages. Its securities are by no means the least precarious of those on sale in the exchanges. This does not mean that such investments involve any special risk that is not presented, either in kind or equivalent, by other standard "industrials." Any project of the hydro-electric industry is profitable or unprofitable according as the expense of development and maintenance and the demand and supply are favorable or otherwise. The industry is subject to the same exigencies as are other industries, and, except in a few cases, notwithstanding the testimony of many popular magazine articles, it bears no resemblance to Aladdin's lamp as a revenue producer. No industry will respond more readily to ill-advised and oppressive legislation; in none must the burden fall more directly on the ultimate consumer. Any hydro-electric project requires special consideration during the early years of its development; a surprisingly large number either fail to pay dividends or become bankrupt during the first decade of their existence.

Notwithstanding the above statements, there is a real menace in the present situation, which holds many problems that are difficult of solution. Certain consolidations of water-power interests have taken place during the last few years, and these, with the appearance of the names of a few persons among the officers or in the directorate of a large number of companies operating water-power plants, making new installations, or manufacturing or marketing water power or electric machinery, point unmistakably to a concentration of ownership and administration in several groups which, in the usual course of events, might consolidate or at least effect a community of agreement. The menace in the prospect lies not so much in this probability as in the ability of such a combination to manipulate unrighteously the public interest. The menace is therefore speculative, but this fact does not obviate the necessity for legislation. The nation and the State are accustomed to legislate against speculative crimes and abuses, because experience shows that in the present state of society mankind is yet frail. What, then, should be the legislation necessary to meet the present conditions?

Consolidation is inevitable. Water power is a natural monopoly by reason of the natural laws of stream flow. Man can not change these laws, and his only course is wisely to adapt himself to them so that they may not operate to his disadvantage. The electric transmission of power developed on water wheels has changed the entire industrial aspect of the matter. When a water power was 
used at the site and its industrial development was limited to its capacity there, no reason existed for consolidation; now the site of a water-power plant is not likely to be its field of operation; its power is distributed over a large area. In this large area there is a common demand for power, and the market constitutes an administrative unit. The demand of the region is a demand in the aggregate. The power on any stream fluctuates with the seasons. The important power demands are those which require a certain steady supply and a large reserve for extraordinary demands or "peak loads." As the demand increases with the development of industry the task of supplying it from one fluctuating stream grows more difficult. The energy developed on several sites or on several streams milust then be transmitted to supply the market. With a still continued increase in demand, more sites and streams must be brought into use. In the final analysis, therefore, all sonrces of power available for a particular field of demand must be brought under a common administration, so that at any time the energy can be turned hither and yon to meet the requirements of each hour. It follows that legislation prohibiting power monopoly must not prevent power consolidation lest it injuriously affect industrial development. There is no virtue in preventing consolidation if economies in maintenance and operation are thereby prevented. No one will deny that water-power consolidation secures distinct and unusual economies, and if the consumer receives the benefit therefrom he is better off under consolidation. These are oft-stated and self-evident truths; therefore the proper solution of the problem must lie in the legislative regulation of water-power development and maintenance, to the end that the consumer shall pay a fair and reasonable price for power, consistent with the production of fair and reasonable earnings on the capital invested.

Up to the time of long-distance transmission of electricity a water power was an essentially local agent of production. The energy derived from the falling water was transmitted by belt and shaft to the near-by machinery which consumed it. Obviously, the field of operation was so localized that the plant was, to all intents and purposes, a private affair. Long-distance transmission of electricity made water power a public utility in every sense of the term. It entered a public market and became a common source of mechanical energy. A public utility is an enterprise in which there exists a public use. Although this term has never been strictly defined in a way that is applicable to all times and cases, the legal principle is well established. Mr. Justice Cooley, in defining a public use, as the term is applied in the law of eminent domain, said:

The reason of the case and the settled practice of every government must be our guide in determining what is or is not to be regarded as a public use, and 
it can only be considered such where the government is supplying its own needs or is furnishing facilities for its citizens in regard to those matters of public necessity, conrenience, or welfare which, on account of their peculiar character and the difficulty of making provision for them otherwise, are proper, useful, and needful for the government to regulate.

This definition may suffice for the statement of principle. It implies that the public, in its sovereign capacity, retains the right of regulation and control in a greater or less degree over the exercise of any function of public consequence. When private property, or the use thereof, becomes a public necessity, or when the owner thereof devotes it to a use in which the public has an interest, he, in effect, grants to the public an interest and must therefore submit to control by the public for the common good to the extent of the interest he has thus created. Moreover, a public utility is absolutely defined by the controlling conditions of the times. That which is juris privati to-day may be a public utility to-morrow. The term must readily adapt itself to new demands and conditions imposed by the ever-increasing necessities of society.

When the principle above indicated is applied to water power under electric transmission, it will be seen that the conditions are satisfactorily met. Mechanical energy is one of the prime necessities of a productive people, and transmitted energy, distributed over an area, must, in the nature of things, dominate the situation. It becomes a public necessity, and when the power is devoted to such use the public acquires an interest therein, just as it acquires an interest in a railroad that, passing through any section of the country, becomes an agent of transportation, which is but another factor of trade and economic progress. It will not be contended that facilities for production are any less important to public interest than facilities for transportation. Viewed from every angle, the public economy in these two factors is identical in principle. One water power or a chain of power's may, under electric transmission, become the seat of productive energy over an area of 500 or 600 square miles, and this area will progressively increase with increase in the efficiency of electric transmission. Therefore present conditions of economic demand on such a source of power have by no means reached their limit, although the principle itself may be fully established.

The important point in connection with all this is that, whereas the appreciation of the people concerning public utility with respect to transportation facilities has been reflected in appropriate legislative acts, the public-utility features with reference to productive energy from water power are not realized, except in a few localities. It is true that for many years a water power from which energy is sold to mills has, under interpretations of the courts, been considered a public utility, but the principle was so limited in its application that, 
previous to electric transmission, it did not impress the people at large with its real significance.

We are now facing the mature condition, and our legislative programme with reference to it is, in the majority of States, not even begun. So far as the attitude of the people is concerned, as represented in their legislative acts, water powers are on the same basis that they were years ago. The condition is equivalent to that which would prevail if our laws respecting transportation were still of the same scope that they were previous to the development of the steam railway. In addition to lack of law there are in some places constitutional limitations, and these are the greatest impediments to the inauguration of appropriate policies. Such is the conservatism of the people with reference to the change of the Constitution that a progressive demand must be apparent for a considerable period before a change is made that will apply to new conditions. Such conservatism is, of course, far preferable to an extreme tendency in the opposite direction, but, inasmuch as a constitution is fundamental law, it can hardly be considered praiseworthy to adhere to such law when the conditions on which it was originally based are so changed that a new field is presented. All this has been recognized in some European countries and in a few of the States of the Union, but the real significance of the present situation has not yet become a matter of common knowledge.

The disadvantages arising from our present unpreparedness to meet the new questions involved in power development and its regulation are not entirely internal. We might postpone action for several years without doing more actual damage to ourselves than to encourage monopolistic tendencies were it not for the fact that there is a matter of foreign competition, as is clearly implied in the following paper. This paper shows that the development of water power has become a national question in France as well as in Italy and in Switzerland. In those countries there has arisen a national policy of regulation and encomragement which will ultimately draw great industries within their borders. The United States now maintains an industrial leadership that can not be retained if other countries pursue policies that more strongly attract manufacturing enterprises. The menace to American industrial leadership is already on the horizon. The water-power sites of Europe are situated close to the great markets of the world. Is there anyone in the United States so confident of this country's industrial leadership as to assert that the wholesale development of these large and cheap powers will not seriously affect our status? Trade and production are entirely cosmopolitan. The cheapest sources of energy will be used, without reference to any particular flag, if they are located in a region convenient to market. This nation has now 
no water-power policy worthy of the name. The President has recognized this defect, and in a special message to Congress on the conservation of natural resources, transmitted Jannary 14, 1910, has advocated a comprehensive measure to meet the situation. Unless this or a similar proposal is adopted the United States must give way to those countries which have well-defined policies.

In many parts of the United States the price of coal is high and water power can be developed with comparative cheapness, so that a low rental price of power will yield a fair profit. The equitable way to maintain such powers is to charge only such rental as will pay a reasonable profit. But this policy is not always adopted. The tendency is to regnlate the price of water power by the cost of steam power. If, for example, the rental of water power at $\$ 25$ per horsepower year will furnish a satisfactory margin of profit, and the cost of steam-power production is $\$ 100$, then the price of water power is fixed not at $\$ 25$, but at a point nearer $\$ 100$. In this way the water power will be a trifle cheaper to the consumer than steam power, and therefore the former will control the market. This is obviously an extreme case. The margin between the cost of the two kinds of power is not usually so wide. The statement does, however, illustrate a common practice. Snch an arrangement obviously does not afford to the community the real saving that should result from water-power development. An industrial power consumer will inevitably compare the results of such a system with the prices and conditions that prevail in foreign countries. This is a mere matter of wise business management. If, in looking over the ground, the consumer finds that under the laws of France or Switzerland he can obtain his power at the $\$ 25$ rate or its equivalent, he is not going to locate in a part of the United States where it is worth only the $\$ 25$ rate but where, by reason of the differential on steam power, it is raised nearly to the limit at which steam power can be produced. Of course other factors than power costs influence the location of any manufacturing plant, but this does not justify the imposition of a handicap on the United States in the shape of unrestrained or unregulated power charges.

The above statements are intended to suggest in a superficial way that in this matter of power development the adjustment of questions in dispute does not merely involve an extended squabble among ourselves. The question has a higher significance, namely, that of the productive leadership of the United States. In the face of the activity of European countries, concerning which no secret is made, there can hardly be any excuse for the postponement of rational and legal measures by this country. The discussion submitted by M. Tavernier in the following pages should not be regarded simply as an interesting dissertation on water powers and their rela- 
tion to political economy, but rather as a lesson from the experience of another enlightened country and a warning that measures at least as foresighted and progressive must be adopted by the States and the nation.

M. Tavernier has selected certain extracts from reports previously made by himself; also certain reports of commissions of the Chamber of Deputies, in which are presented and discussed sundry legislative proposals. All of this is supplemented by a presentation of various laws enacted by certain States of the Union and a general introductory discussion of the popular and legislative status of water power in the United States, which has been prepared by the coanthor. 


\section{CHAPTER II.}

\section{HYDRAULIC POWER AND IRRIGATION.}

\section{By René Tavernier.}

\section{GENERAL STATEMENT.}

It was little more than thirty years ago, shortly before the wellknown experiments of Desprez concerning the electric transmission of power, that French engineers began to perceive the use that could be made of the power of flowing water. A hydraulic power plant, operated by a waterfall 500 meters (1,640 feet) in height, built by $M$. Berges for the use of his paper mill in the Isère Valley near Grenoble, drew attention to the large number of similar industrial opportunities throughout the French Alps.

The example of M. Berges found a number of imitators. Between 1880 and 1890 several manufacturers in the valleys of Arc and Romanche rivers made use of the streams and falls of that region for eleetro-metalhurgical and electro-chemical purposes. The first great hydraulic plant designed to produce power for public distribution was erected in the period between 1888 and 1898 on Rhone River above Lyons, at the town of Jonage. By the year 1900 such plants had become so numerous as to call for a governmental investigation of their possible effects on the future work of certain branches of the public administration, particularly that of the division of irrigation.

On August 12, 1899, the writer prepared a report containing detailed information concerning the exploitation of this new variety of wealth, which in France has been somewhat metaphorically called "white coal "_." la houille blanche"-and the means by which public service enterprises using hydro-electric power, as well as those concerns whose operation is affected by the diverting or damming of streams, may be enabled to participate in this exploitation and derive profit from it. ${ }^{a}$

Among the enterprises that simply consume hydro-electric motive power should first be mentioned the great railway systems, which in France, as every one knows, are leased by the State to private corpo-

\footnotetext{
${ }^{a}$ Les forces hydrauliques des Aipes en France, en Italie, en Suisse; statistique-mode d'utilization-législation : Rapport de mission de M. René Tavernier, ingênieur en chef des ponts et chaussées (Annales des Ponts et C'haussées, 1900). (See pp. 37-73.)
} 
rations and which revert to the State at the expiration of the leases; among those whose development and prosperity are even more directly affected by the production and utilization of hydraulic power are navigation (confined to navigable streams) and irrigation (extending to all streams).

This paper, written entirely with regard to the interests and needs of agriculture, is intended to emphasize the close interdependence of irrigation plants-particularly their future expansion and utilization-and the industrial employment of hydraulic power. Its statements apply especially to France and are probably not sufficiently general in character to be applicable without modification to all other countries. France is densely populated, and a relatively large number of her inhabitants own the farms that they cultivate or the shops or businesses that they manage. Neither manufacturing nor agriculture is there conducted on so large a scale as in America, nor does either play a predominant part in any one section of the country, as in the United States, where some of the separate States are mainly agricultural and others mainly industrial. In almost every portion of France agriculture and manufactures are distributed almost evenly and play parts of about equal prominence. ${ }^{a}$

'This problem of the more satisfactory utilization of streams, which is bound to arise sooner or later nearly everywhere, presents peculiar difficulties in France because of the entanglement of economic interests and the conflict of legal privileges which are involved. Few streams are serviceable for only one purpose. Since time immemorial the right to use even little brooks and creeks has been a matter of dispute between individuals; and now that the larger streams have suddenly acquired very considerable economic importance the conflict of interests is more vital. In seeking the better utilization of streams it is often necessary to defend the future needs of agriculture, which provides a livelihood for a large population without enriching those who are engaged in it, against the encroachments of manufacturing plants whose exclusive purpose is the earning of large profits.

We shall consider, first, the relations between hydraulic power production and soil irrigation; and then discuss the investigations made by the French ministry of agriculture, as well as the measures which it has already taken or proposes to take in this comnection.

\section{INFLUENCE OF INDUSTRIAL UTILIZATION OF HYDRAU- IIC POWER ON DEVELOPMENT OF IRRIGATION.}

The proper discussion of the question indicated by the above heading requires the consideration of the following three topics: 
(1) The methods of irrigation employed in France; (2) the economic features that are peculiar to hydraulic power enterprises; and (3) the relations between these $t$ wo sorts of enterprises, including the mutual help that they can render under certain circumstances and the harm which, under other circumstances, they are apt to inflict upon each other.

\section{FRENCH IRRIGATION METHODS.}

A lengthy exposition of this subject may be dispensed with by referring the investigator to the following works:

Barral: Les irrigations dans les Bouches-du-Rhône.

Barral: Les irrigations dans Vaucluse.

Barral: Les irrigations dans la Haute-Vienne.

Annales de la directions de l'hydraulique et des améliorations agricoles (parts 26 to 34 ).

Reports of the International Congress of Engineers at St. Louis, Mo., U. S. A., irrigation section. (In Euglish.)

M. Lévy-Salvador: Irrigation and hydraulic motors used in irrigation in France.

Prevost, M., Ingénieur an ministère des colonies: Rapport sur les irrigations aux colonies.

Alimentation artificielle de la rivière de Neste.

Note sur le service de l'hydraulique et des améliorations agricoles.

Map, on a scale of 1 to 5,000 , of the basin of Durance River and its tributaries.

Particular attention is directed to the short article on irrigation by M. Lévy-Salvador, which has been translated into English $a$ and which gives the reader a general idea of the various methods used in different parts of France. As agronomic questions will not here be discussed, but attention will be devoted exclusively to the mechanical or engineering aspects of irrigation, the means by which water is carried to the soil to be irrigated, it may be stated, in agreement with M. Lévy-Salvador, that two methods have always been in vogue. With the first method surface water or underground water is pumped at the point where it is to be utilized; with the second it is led through gravity canals and ditches from some point at a distance, where the level is sufficiently high, to the place where it is to be used. Each of these methods has heretofore had its own peculiar advantages under given circumstances. Pumping has been used especially for private small-scale irrigation, where small volumes of water were used separately and pumped to relatively low altitudes; but the method of diverting the requisite water has always been regarded as a more economical way to provide large quantities of water for the irrigation of groups of farms collectively.

But the purely mechanical superiority of the diversion method was conjoined with a commercial inferiority which explains the financial 
failure of the newest large irrigation plants. This commercial inferiority was due to various causes which, in the last analysis, all had a common origin in the fact that the small farmers interested in the collective enterprises were very numerous and possessed extremely scanty financial means. In France, as in some other countries, the demand was not for an irrigation system adapted to the needs and resources of a small number of large landed proprietor's who could easily be persuaded to combine themselves in a venture of financial magnitude or who cultivate a virgin soil which is apt to increase sufficiently in value to yield large profits to the promoters. The numerous landowners whose farms require irrigation must be led to unite and they must pledge themselves for a long period-forty years or more-in order to insure the continued operation of the irrigation plant. In spite of very large subsidies (often amounting to half the cost) granted by the French ministry of agriculture, disasters of two kinds have arisen.

1. Landowners who have subscribed-ill-advisedly-for the watering of a relatively large acreage have been mable to earn any profits, because of the poor quality of the soil, the great distance from the market, or the insufficiency of their capital. For it should be noted that the change from arid soil and extensive methods of farming to irrigated soil and intensive methods involves not only the expense of irrigation itself, but also the oftentimes heavy burden of altering methods, new implements, and a different management. The farmer who can not meet these demands and adheres to the old methods of cultivation finds that the water which he has so dearly bought does not result in a sufficient increase in the value of his crops. ${ }^{a}$

2. The owners of the plant find unfulfilled, as a result of the same circumstances, their own reasonable hopes for expanding demand for irrigation and hence increasing profits.

The disappointment of some of the early subscribers to the enterprise also dissuades possible new ones. Even the method of selling the water, namely, by requiring the purchaser to pledge himself for a long period and for a certain number of acres, without the possibility of subsequent modification, is altogether unbusiness-like. Intensive farming, like most other occupations, is subject to shifting and fluctuation and does not permit rigid calculations made in advance for long periods of time. Some farmers would be willing to try an experiment, but wonld not dare to bind themselves for a term of years. ${ }^{b}$

\footnotetext{
a The usual prices, varying from 40 to 60 franes per hectare per annum (about $\$ 3$ to $\$ 4$ per acre per annum), entitle the purchaser to a quantity of water equivalent to a flow of 1 liter ( 0.035 cubic foot) per second, furnishing a depth of 6 centimeters ( 2.4 inches) every week for six months of the year.

$b$ The similarity of difficulties in connection with cooperative enterprises in the arid West of the United States is worthy of remark.-M. O. L.
} 
It is easy to understand, moreover, that in time these difficulties will probably disappear. Landowners learn to make good use of the water, and those who do not at first possess sufficient means or knowledge acquire them gradually, or their places are taken by others who are more resoniceful. Furthermore, numerous farmers' unions and cooperative associations interested in the social reform movements now so active in France have provided groups of associated farmers with all the resources formerly enjoyed only by large landowners.

Finally, the department of agriculture, by means of a newly created service-" the agricultural improvements service," complementary to the hydranlic service-is itself endeavoring to aid irrigators to the best possible utilization of water. ${ }^{a}$

Many of the older irrigation plants have reduced their charges and better adipted themselves to local conditions, thus, in the long rum, bringing about fortunate transformations and spreading prosperity in the regions where they are located. It would be wrong, therefore, to conclude that because some of the large systems of irrigation canals recently built in the valleys of the Rhone and the Durance were financial failures irrigation does not constitute in the sonth of France, or in countries presenting similar climatic conditions, a most efficient means of increasing agricultural productivity.

But it is equally comprehensible-and this is the main point of the foregoing remarks-that the ministry of agriculture hesitates to subsidize new irrigation enterprises while those most recently completed have not yet produced the results which were anticipated; and that the Government prefers to seek some solution which shall offer, among other advantages, that of not involving large expenditures made too long before the time when they can become profitable.

In the following paragraphs we shall consider to what extent the results of the utilization for productive purposes of the so-called "white coal" will retard or facilitate the discovery of a solution.

\section{ECONOMIC NATURE OF BUSINESS ENTERPRISES EMPLOYING HYDRAULIC POWER.}

Up to the end of the last century small hydraulic plants and water mills, which were very numerous in France, employed only a small fraction of the total water power of the comtry. In 1890, according to the statistics of the department of agricultural hydraulics, these concerns numbered 69,620 for the whole of France, with a gross productivity of 1,028,807 horsepower, equivalent, because of the small yield of very imperfect appliances, to an effective horsepower of only

a See bulletin entitled "Review of the work of the bureau of hydraulles and agricultural improvements," a translation of which appears herein (pp. 93-107). 
one-third that amount. The average productivity of each mill or plant was 14 horsepower gross and 5 horsepower net. These small plants, when erected upon streams well supplied with water, generally used only a fractional part of the available power and water and left the remainder available for other purposes, such as irrigation. But this is not the case with large modern power installations, where a single plant gathers up several thousand horsepower. In the region of the French Alps alone-which, to be sure, is best provided with hydraulic power-there are 90 plants producing a total maximum of 325,000 horsepower, measured at the turbine axle, or an average of 3,600 horsepower for each concern.

The report of the writer, referred to on page 12, contains numerous facts concerning the cost of first establishment and of maintenance and operation and methods of utilization of large modern waterpower plants. Since that report was written (in August, 1899), the "white coal" industry has made rapid progress. But the broad features of its evolution are marked in the schedule prepared more than ten years ago. Some modifications should, however, be made therein. As the laws authorizing expropriation have not yet been put to a vote, the riparian owners and intermediaries of all classes, having come to a greater realization of the value of water powers, have raised their prices to a considerable degree. The sum of 100 francs $(\$ 20)$ per horsepower, taken in 1899 as representing the total expense of first installation of water-power works, is to-day in some places entirely absorbed in the mere acquisition of riparian rights.

Another feature in the progress made during ten years in the method of utilizing large water-power plants is indicated by the large power-distribution enterprises. Such enterprises, employing the technical inventions that continue to extend the practical limits of long-distance transmission, have sprung up in various parts of France in which water powers are located-principally in the sontheast, in the region of the Alps, and in the sonthwest, in the region of the Pyrenees-just as, during the past ten years, the large railway systems have grown by combinations and successive extensions. The analogy between these two economic phenomena is striking.

To make the large railroad companies respect the principle of equality in treatment of the people, to safeguard industrial and commercial liberty, has been the universal endeavor, and the value of the results has varied with the efficacy of the precautions adopted. The experience acquired in the past in the exploitation of railroads must be applied to the better organization of the public services for power distribution.

The new tendency is to build, at the very start, a series of canals that will divert the entire low-water flow of the streams. Many of the large plants are fitted up not only for operating with the mini- 
mum flow that can be counted on at all times of the year, but also for using the average flow such as may be reckoned on more or less irregularly during onty eight, six, or even fewer months of the year.

It is evident that such an elaborate undertaking-sometimes called a "complete" plant-is likely to jeopardize the development of irrigation unless some precaution is exercised. Of course existing provisions for irrigation are not interfered with. There is even a disposition to allow a certain "margin," which takes into account the probable demands of the future, based on the needs of the past. But when new irrigation enterprises are projected after such "complete" power plants have been built they are apt to come into conflict with vested privileges upon which it is impossible to encroach without indemnification.

It is true that hydraulic plants do not actually use up the water itself, which is ahways available for application to the soil after it has passed through the wheels. They do not interfere with the use of the water for irrigation below the point of exit. They prevent its use above that point. They consume the fall necessary to carry the water to the fields lying at altitudes between the upper and lower levels of the power plant. Hence the erection of one of these "complete" or integral power plants amounts simply to appropriating the impetus of the stream, which also constitutes, so to speak, the "energy" necessary for watering the soils that might benefit by irrigation. It may be more profitable for all parties-as we shall attempt to show later-to resort to the system of storing up this "energy" rather" than to that of storing up water taken at the upper level of the fall. But before considering this question we must clearly grasp the dissimilar economic characteristics of the varions types of hydraulic plants-characteristics that depend upon such circumstances as the altitude of the fall, the volume of water and its fluctuations, whether the stream is tapped by a channel at a higher level or the water dammed at the point of use, and whether it is possible to accumulate the flow and to regulate the plant without loss of water but in accordance with the demands of its customers.

In France the productivity in horsepower of a hydraulic plant is calculated by means of the following very simple formula: $\mathrm{P}=\mathrm{H} \times \mathrm{Q} \times 10$, in which $\mathrm{H}$ is the height of the fall in meters and $\mathrm{Q}$ the discharge in cubic meters per second. 'This gives us the gross productivity in horsepower, each of 100 kilogram-meters ${ }^{a}$ per second, which corresponds at the turbine axle-assuming a net yield of 75 per cent-to a horsepower of 75 kilogram-meters per second.

But the industrial value of a power plant is not measured solely by its power thus calculated. In the first place, the formula is inapplicable to a plant using, in addition to a permanent minimum flow 
of water, a certain average intermittent volume. An irregular power is manifestly not equivalent to a uniform power, when the irregularity is independent of the requirements of consumption and is governed solely by fluctuations in the condition of the stream. On the other hand, if a plant is equipped with facilities for storing up the natural flow of the stream for a time at a higher level in order to make use of it at the periods of maximum consumption, irregularity in the production of energy becomes subject to control and constitutes a source of large additional gain. It should be remarked, moreover, that these profit-creating reservoirs are much more effective and economical with high than with low head plants. Compare, in this respect, two hydraulic plants of 10,000 horsepower each, one receiving a flow of 71 cubic feet ( 2 cubic meters) per second, with a fall of 1,640 feet (500 meters), and the other a flow of 7,100 cubic feet (200 cubic meters) per second, with a fall of 16.4 feet ( 5 meters). A reservoir of $2,542,600$ cubic feet or about 58 acre-feet $(72,000$ cubic meters) would suffice, in the first case, to store up the total discharge of ten hours, enabling that plant to vary its production sufficiently to provide for the widest fluctuations in the daily demand. In the second case a reservoir 100 times as large-that is, with a capacity of 254,260,000 cubic feet or about 5,800 acre-feet $(7,200,000$ cubic meters) - would be needed to obtain the same results. High falls therefore admit much more readily than low falls of being so equipped as to produce power at the precise time of the day when it is wanted. But they may play an even more important part. Imagine a poorly fed basin in a mountainous region receiving during the year by irregular discharges a total volume of water equaling a regular and uninterrupted flow of 3.5 cubic feet (100 liters) per second. With a reservoir having a capacity of $83,794,000$ cubic feet or about 1,902 acre-feet $(2,372,840$ cubic meters) the water could be stored during nine months in order to let it flow during the remaining three months. If the height of the fall is 1,640 feet (500 meters), the creation of this reservoir would mean substituting for an average force of 500 horsepower, that is altogether useless because of irregularity of the flow, an additional force of 2,000 horsepower that is extremely valuable because it may be used at the very season when it is needed. Here we have a "seasonal" regularity, which not only enables us to meet varying seasonal demands, like those of agriculture or of the distribution of electric light, but which also makes it possible, whenever several plants are concurrently engaged in furnishing power for one distributing concern, to come to the aid of those plants whose productivity is intermittent and not subject to such regulation.

In short, it will readily be seen that the industrial value of a large hydraulic plant does not depend solely on the maximum amount of 
power that may be produced, but differs considerably as the power is produced permanently and regularly or intermittently, and also according to the extent and nature of the irregularity. Unavoidable and unforeseen irregularities in power production, due to the effect of changes of wind and weather on the condition of rivers, cause an enormous diminution in the industrial value of a hydraulic plant. But when the production of power is subject to such regulation and control as is made possible by reserve supplies of water, fluctuation:i in production may be made to coincide with fluctuations in demand.

The various systems of producing hydro-electric power having been characterized, a word should now be said as to the nature of the market. Thus considered, hydraulic plants may be divided into two very distinct groups-(1) isolated plants built in connection with various sorts of industrial enterprises, such as electro-metallurgical or electro-chemical manufactures, and adapted to the permanent or variable needs of productivity of the enterprises concerned; such plants, sufficient unto themselves, are essentially private and nothing need be said of them except that they are chicfly found in mountainous regions; (2) plants that supply power for one or more enterprises and are designed to furnish the public with motive energy. These plants are of interest here because economy requires that the various uses of the motive power thus distributed should include a sufficient provision for pumping water for irrigation.

The hydro-electric power supplied by such plants will be in demand by many kinds of consumers with exceedingly varied needs. For illumination the motive power is needed at certain definite times and during a limited period of two or three hours on an average day. ${ }^{a}$

The power needed by motors used in manufacturing concerns is required for periods as long as the workday of the laborers. The demands for traction depend on the time-tables of the railway companies or of the street-car companies. All these enterprises, which are rather irregular and capricious in the need of power, nevertheless require that power at certain very specific times. It is natural that the price which must be paid should be proportionate to the specific demands, and this, as a matter of fact, is the practice in France, as is shown by the following table of rates customary in France:

Cost per kilowatt-hour.

For illumination 50 to 80 centimes $(10-16$ cents $)$.

For small quantities of 20 to 50

horsepower -.........---.-.--

For larger amount of power

transmitted some distance.

9 to 20 centimes $(2-4$ cents).

For power furnished at the busi-

ness place itself

4 to 6 centimes $(8-12$ mills $)$.

1 to 3 centimes (2-6 mills).

a This evidently refers to the "peak load" for lighting.-M. O. L. 
The organization of large corporations for the public sale and distribution of power furnished by hydraulic plants is sufficiently advanced in certain parts of France, such as the southeastern region, to indicate the essential tendency of such concerns, which is to bring together into a systematic unit, by means of electrical connection, all the power-producing plants and all the consumers of power in a given section of the country.

A consolidation of this sort is being effected between Nice and Montpellier by the Société de l'énergie électrique du littoral Méditerranéen. A similar monopolistic tendency is drawing together the central steam-power plants, which have been established in the cities by the street-car companies, or the older electric-light plants, which are still maintained to serve as emergency stations to help out the hydraulic plants at times of accident or unusual demands for power. It frequently happens that steam plants are operated a few hours daily to furnish a sufficient margin of power to insure against possible shortages through unusual demands (peak loads). But the part played by such emergency steam plants will diminish to the extent that the flow of streams is made more regular through the use of reservoirs and the erection of "regulating" hydraulic plants.

A concern which thus monopolizes, throughout a vast region, all the different varieties of hydraulic energy, correcting the weak features of each variety by means of systematic organization and control, engrossing the entire market for power, and regulating the tota? production by virtue of the simple fact that the demand is ever becoming greater and more varied, possesses such great economic and commercial advantages that no independent concern is in a position to furnish power for any special purpose at a lower price.

The various uses which we have enumerated, with the exception of electro-metallurgical manufactures (which are able to make good and complete use of a great hydraulic power plant), can not be economically provided with power by the separate concerns themselves. A hydraulic power plant built for the special purpose of illumination or traction is necessarily imperfectly and only partially utilized, because the unused residues of power are apt to be considerable.

Undoubtedly the rational "trustification" of the distribution of hydro-electric power has thus far been confined to southeastern France. But, inasmuch as irrigation is most advanced and best developed in that region, and inasmuch as the same evolution is likely to take place elsewhere, it is interesting to inquire what care may be taken under such circumstances to safeguard and foster the reasonable needs of agriculture, and under what conditions hydroelectric power may be equitably utilized to pump water for irrigation as well as for the other uses required by the public. 


\section{USE OF HYDRAULIC PLANTS IN THE DEVELOPMENT OF IRRIGATION.}

Pending the discovery of new methods of bringing water for purposes of irrigation to the places where it is needed, it would be absurd to condemn the old methods and to insist unduly upon the general application of the methods about to be described. Many isolated and independent irrigation enterprises will undoubtedly continue to be justified; but, while the industrial utilization of streams is made on a large scale, as on Durance River and its tributaries, it is questionable whether the separateness of irrigation enterprises does not constitute a source of weakness and a hindrance, and whether a possible antagonism of interests in the future might not be avoided by bringing together several systems for utilizing the streams.

From purely mechanical considerations, it may at first seem surprising that there should be an advantage in employing expensive mechanical derices, such as turbines and dynamos, whose use results in considerable loss of energy, rather than in continuing the exclusive use of gravitation. But a little reflection suffices to justify this conclusion as to the relative merits of the two systems.

We must first of all eliminate from the discussion the objection of "lost energy." Without carrying the comparison very far, it is easy to estimate a priori the loss of energy involved in the usual system of irrigating by diverting streams-losses which are due to the excessive slope of small trenches, and, above all, to the fact that the large accumulating channels carry all the water to the highest level of the area to be irrigated, without the possibility, as a rule, of diverting any considerable portion of the propulsive power of the water that is employed at lower levels.

By the use of separate pumps, each of which raises to the necessary level the water needed for irrigating at that particular level, the greater part of this loss of energy may be avoided. Moreover, very considerable losses of water caused by the long main channels may be avoided by a series of separate pumping stations. ${ }^{a}$ Finally, whether it is utilized or not, the maximum volume of water flowing into a large irrigation trench should always be available. Under the system of pumping stations the quantity of water brought to a given level corresponds exactly to the requirements of the consumers. Without doubt, in the gravity system of conducting the water the total waste of water or of power does not greatly exceed the mechanical loss due to electric transformation and to the transmission of power made necessary by the pumping process.

a The Bourne channel furnisbes a typical example of the magnitude of these losses of water, which, In this instance, exceeds half the entire volume that is diverted into the channel. 
From considerations of original expenditure and trouble of maintenance, the complexity of mechanical and electric installations, compared with the simplicity of a channel which accomplishes this work by means of its slope, would constitute a marked disadvantage in the new process if we were simply comparing two isolated and autonomous enterprises; but our hypothesis assumes that in pumping we have to do with a large enterprise for producing and distributing hydro-electric energy and furnishing water for a large number of irrigation areas as well as other public and private uses.

Isolated irrigation plants in this way escape the difficulties connected with the production and transmission of power; they receive for a fixed price the power required to carry the water to the desired level; and the financial superiority of the pumping station is thus due to the fact that the annual expense of the station, added to the cost of maintenance and keeping the plant in repair, is lower than the annual cost of constructing and maintaining the main channel in the system of diverting streams.

The following figures will give some idea of the height to which water may be pumped without greater costs than those usually incurred in agriculture:

Watering 2.471 acres (1 hectare) of land with a volume of water equaling a continuous discharge of 0.035 cubic foot (1 liter) per second for six months will mean, if the water is raised 39.37 inches (1 meter) a power in pumped water of $\frac{1}{15} \overline{0}$ horsepower throughout the year, or of 42.98 kilowatt-hours. If the total yield of the pumping station is 60 per cent, including dynamo, pump, and pipes, the annual consumption of power will be 71.6 kilowatt-hours, and the cost, at a rate of $\frac{1}{5}$ cent ( 1 centime) per kilowatt-hour will be 14 cents ( 71.6 centimes). If the price per kilowatt-hour is $\mathrm{X}$ centimes and the elevation $\mathrm{N}$ meters, the annual expenses for pumping the water necessary to irrigate a hectare, according to the formula $0.716 \mathrm{XN}$, will be as follows:

Cost, in francs, of pumping water necessary for irrigating 1 hectare ( 1 liter per second).

\begin{tabular}{|c|c|c|c|c|c|}
\hline \multirow{2}{*}{$\begin{array}{c}\text { Height } \\
\text { (meters). }\end{array}$} & \multicolumn{5}{|c|}{$\begin{array}{l}\text { Cost when price of kilowatt hour, in } \\
\text { franes, is- }\end{array}$} \\
\hline & 0.01 & 0.02 & 0.03 & 0.01 & 0.05 \\
\hline $\begin{array}{l}10 \ldots \ldots \ldots \ldots \\
20 \ldots \ldots \ldots \ldots \\
30 \ldots \ldots \ldots \ldots \\
40 \ldots \ldots \ldots \ldots\end{array}$ & $\begin{array}{r}7.16 \\
14.32 \\
21.48 \\
28.64 \\
35.80\end{array}$ & $\begin{array}{l}14.32 \\
28.64 \\
42.96 \\
57.28 \\
71.60\end{array}$ & $\begin{array}{r}21.48 \\
42.96 \\
64.44 \\
85.92 \\
107.40\end{array}$ & $\begin{array}{r}28.64 \\
57.28 \\
85.92 \\
114.56 \\
143.20\end{array}$ & $\begin{array}{r}35.80 \\
71.70 \\
107.40 \\
143.20 \\
179.00\end{array}$ \\
\hline
\end{tabular}


These figures may be compared with the cost per liter per second diverted by some of the great irrigation canals in southeastern France:

Cost per liter per seeond (equivalent to watering 1 heetare) of water from canals in southeastern France.

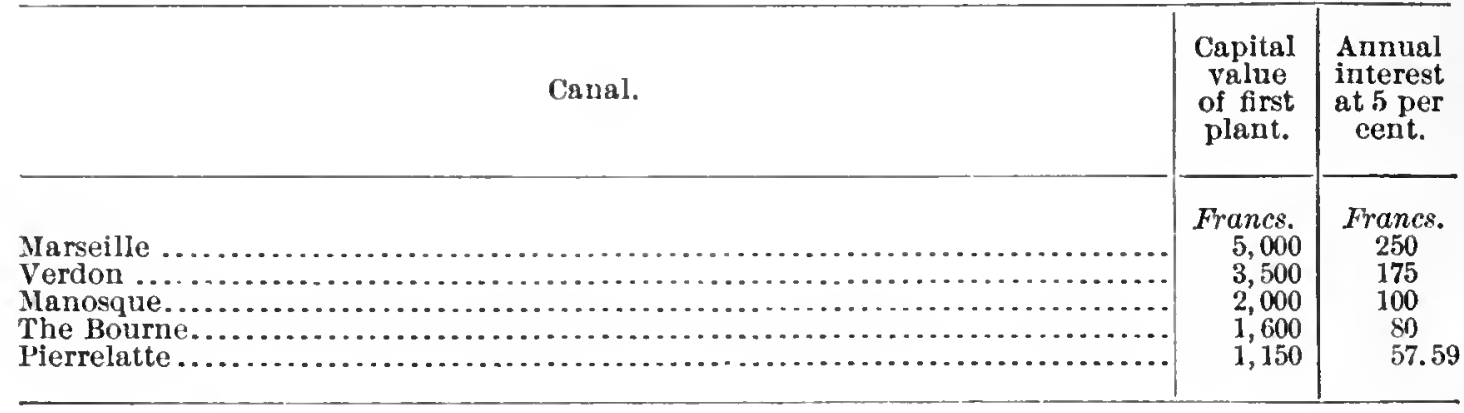

Even when reduced to this definite basis, the comparison is rather difficult to make and is subject to some variation. For the pumping stations one may employ either a continuous supply of power furnished at the average price charged by the distributing plant or the residues of power provided intermittently at lower prices.

Irrigation plants may, in fact, prove less exacting than lighting or traction plants as regards the period and the duration of power consumption. They ma either utilize regularly and fully the power produced continuously by the hydranlic plant, or utilize only for certain hours daily the residnes which are available in every plant that furnishes power to be distributed to a considerable number of different concerns.

Intermittent pumping, compared with continuous pumping, involves certain supplementary costs and expenses of maintenance. The capacity of the pumps themselves must be augmented as well as that of the main trenches. Moreover, unless reservoirs are built along the distributing trenches the soil can be watered only at certain times, determined by the times when the residues of power are available. These costs and difficulties must be compared with the saving effected by the reduction in the price of power. It would surely be equitable to insist on a considerable reduction in price for residues of power for which no other use than pumping can be found. Two considerations, however, may stand in the way of such a reduction. It may happen that the amount of these residues is diminished by the steampower plants that provide power in cases of emergency. We have pointed out that this is true in the large power-distributing plant that supplies the southeastern part of France. It may also be urged that the furnishing of power for irrigation during a period limited to six months or less per annum involves leaving, during the remaining six months, additional residues of power very difficult of disposal. 
The devices to be adopted to obviate these difficulties and to enable pumping stations to obtain their power at the lowest possible prices depend on conditions peculiar to each particular plant and region. Thus, for example, where streams are fed by melting snow and glaciers, as in the valley of the Durance, it is possible to obtain a greater supply of power at the very season when the demands of irrigation require it. The warmth that fosters vegetation also causes an abundance of water in glacier-fed streams. This fortunate coincidence is perfectly satisfactory at the beginning of the irrigation period but does not always last to the end. There is often a shortage in September in the valley of the lower Durance. The construction of large reservoirs, the possibility of which is now being investigated, will prevent shortages and at the same time insure regularity in the production of hydro-electric power.

In the writer's opinion, the chief advantage of a system of pumping by hydro-electric power is that the energy may be furnished by a great distributing plant which supplies a whole region with power. This permits dividing the work of irrigation among a number of successive stations, erecting at the outset only those that are likely to be remunerative, and keeping pace with the natural growth of the demand for irrigation instead of tying up capital for a long time before it becomes productive. The adoption of such a plan will remove the principal canse of the financial failure of the large irrigation systems recently built.

Again, under this system, the benefits of watering the soil are no longer confined to areas that can be reached by the large gravity channels which are so difficult to build and require so much time. Considering the probable rapid spread and development of large distributing plants for hydro-electric power, it may be said that if the price charged per kilowatt-hour is fixed low enough, our entire territory may be irrigated by pumping on a larger or smaller scale. However cheap a kilowatt-hour may be, the areas devoted to extensive farming will be unable to stand a charge of more than $\$ 3.25$ to $\$ 4$ per acre (40 to 50 franes per hectare), and hence can not buy the water if it must be carried to too high an altitude, but this will not be true of truck farming in the neighborhood of cities. In many places it will be profitable to supply both the city and its environs by having the same plant provide drinking water, and thus obtaining the large receipts which this involves. Underground waters, as well as surface waters, accumulated in reservoirs will then be supplied to the soils which make the best use of them.

Each stream can thus be employed to the best purpose, either as a water supply or in producing motive power. Thus water power of the Durance, which at the periods of low water does not supply suf- 
ficient water for irrigation of all lands in its lower basin, conld be used to lessen the disastrous effects of such shortages by developing power in the highlands to pump from the Rhone to irrigate a portion of the area now watered by one of the canals supplied by the Durance. Numerous contrivances to effect this result will then become possible. But enough has been said to give some idea of the advantages to be obtained. The administrative measures and the legislative reforms designed to facilitate these changes, which are under consideration by the minister of agriculture, will now be discussed.

\section{MEASURES ADOPTED BY THE MINISTRY OF AGRICUL- TURE TO HARMONIZE THE DEVELOPMENT OF IRRIGA- TION WITH INDUSTRIAL UTILIZATION OF STREAMS.}

Two kinds of general measures are adopted by the French ministry of agriculture to induce industrial plants that use water power to cooperate in the growth and development of irrigation; the first aim to make a complete and detailed study of streams; the second have to do with the licensing of hydraulic-power plants. A few data will be presented on each of these points and, by way of example, the special investigations now under way will be indicated.

\section{BUREAU FOR INVESTIGATION OF HYDRAULIC POWER.}

Investigation of stream flow.--It is evident that the rational development of hydraulic power, involving the employment, at the lowest possible price, of a portion of the power for pumping water for irrigation must be based above all on a thorough knowledge of the precise nature of streams and of all other surface accumulations of water that admit of direct use. Investigations of this sort were authorized by the minister of agriculture in 1903 under the joint direction, so far as the Alpine region was concerned, of Chief Engineer $R$. de la Brosse and the present writer. The expenditures in the region of the Alps alone amounted to about $\$ 20,000$ (100,000 francs). It will be of advantage to summarize from the report of that investigation, ${ }^{a}$ published in 1905 , the main features of the plan then pursued, which was entirely analogous to that being followed upon a larger scale by the engineers of the water-resources branch of the United States Geologieal Survey.

The plan has a twofold object-first, the purely physical investigation, geographic, meteorologic, and hydrographic, of streams and their beds; second, the economic investigation of the questions raised by the utilization of the energy produced by water or by the use of water.

a Ministère de l'agriculture-Innales-Direction de l'hydraullque et des amellorations agricoles, fasc. 32 ; tome 1 , Organization et eompte-rendu des travaux; tome 2, Résultats des êtudes et travaux. 
No one will contend that it is possible in the hydrographic study of streams and their channels to pay attention to the lines of jurisdiction that divide the different Departments of the Government. The economic and legal discussions of the matters fundamental to the "white coal" industry have brought out certain facts clearly. The best utilization of a stream will almost always be a varied one, recognizing the complex interests of agriculture, manufactures, and public-service utilities of all kinds. It is therefore imperative that the entire subject be studied regardless of artificial lines of subdivision-not in order to place obstacles in the way of manufacturers, but to provide them with precise data, lacking which they might undertake disastrous schemes, and also to furnish a basis of action for the Government. The "white coal" congress, held at Grenoble in September, 1902, adopted a resolution to this effect, which contained valid arguments. If we compare the spread of the hydroelectric industry in the French, Swiss, and Italian Alps, we will discover that the exact determination of the hydraulic power of our streams is much less advanced than in the neighboring countries, and that the meagerness and inaccuracy of the data upon which the first enterprises were launched in France have been the cause of some unsatisfactory results. The following statements are applicable only to the Alpine region comprised between the Rhone and the FrancoSwiss and Italian frontiers.

Number of measurement stations.-The number of stations which should be maintained in the Alps to determine with some degree of precision the hydraulic power of the streams can not be estimated at less than 200, which would mean an average of 20 for each Department, or 0.30 per square myriameter (1 station for each 129 square miles). The stations already built are still far from being equipped with all the apparatus necessary for doing good work, but efforts are being made to equip them as rapidly as the available funds permit.

Utility of a preliminary estimate.-It will be several years before we are in a position to give accurate information concerning the régime of Alpine streams, but we have undertaken from the start to coordinate such data as we possess, making use even of those that are incomplete and hypothetical, so that it would be possible to prepare a sort of provisory inventory, which might be rectified from time to time and brought up to date. This first task will make plain the deficiencies in data. It will be a sort of sketch, with blank spaces that will be gradually filled ont and perfected by substituting every year, for the approximate data previously used, the more exact figures resulting from a longer experience.

Practical nature of the results to be obtained.-Our principal purpose has been to give our investigations a practical character which would permit their immediate utilization-subject, of course, to the 
reservations imposed by the approximate nature and the small number of the investigations already made. It may not be a waste of time to offer certain explanations upon this subject. To build and equip a channel for diverting part of a stream it is necessary to know its slope, its volume, and the speed of its current.

The determination of slope, although it costs something, offers no difficulties. It is done by finding the difference of levels. The division of public surveys in France is engaged in placing in all the Alpine valleys numerous bench marks, by means of which the total slope of different streams can be calculated. This operation, if done once for all, will greatly facilitate the erection of power plants; meanwhile special surveys will have to be made for those plants which it is proposed to erect now.

The flow and volume of the streams, howerer, can not so easily be determined, but as they constitute the most uncertain and variable elements of hydraulic power, it is important that the fluctuations be measured exactly. Not only should we know the flow at extremely low or extremely high stages, but also the duration of the various intermediate conditions during the year, and the times that they occur. Moreover, we should possess data covering a large number of years in order to determine averages with which to compare extreme fluctuations in very dry or very wet years. French manufacturers, rightly enough, have not been content to utilize a minimum flow; they employ also, during a certain number of months, a portion of the average volume; and it would help them greatly to know, upon the basis of long-continued investigation, the elements that affect the fluctuations in the flow of the streams.

We have not been satisfied, in seeking an exact method of measuring the industrial value of a stream, to make use of such vague expressions as "ordinary low stages," or " ordinary average volumes," or even of other more exact terms like "extreme low-water stage," which, in spite of their scientific precision, do not furnish a practical basis of evaluation. It was suggested at the "white coal " congress that the industrial value of streams not artificially regulated by reservoirs be indicated by two volumes, viz, the normal level below which the stream falls, in an average year, during ten days in the year, and the normal volume below which the stream falls during one hundred and eighty days in the year.

The paper presented to the Grenoble congress on this subject inchuded useful data for the graphic determination of these two normal volumes, and for deducing all the requisite practical conclusions from the curve of average monthly volumes. For more details the reader shonld consult the original paper, ${ }^{a}$ bearing in mind

a Tavernier, René, Influence des neiges and des glaciers sur le régime des cours d'eau : Annales Direction de l'hydraulique et des améliorations agricoles, fasc. 32, tome 1, pp. $145-153$. 
that the determination of normal volumes by either of the methods indicated is based on a knowledge of the average daily flow deduced from hydrometric readings by the aid of a formula specially designed to determine the coefficients needed.

This method of estimating hydraulic forces employs only hydrometric observations and measurements. It does not make use of rain measurements, geologic and glaciologic data, etc., although such studies are proposed, and it is evident that great practical interest attaches to the determination of the different elements that affect stream flow in each basin and of the extent to which they contribute to permanency in the volume of the stream. When these studies have been made we shall be in a position to understand the original causes of those variations which fix and limit the amount of hydraulic power; and in the course of time we shall discover rules which will permit us to use a simple substitute for the direct and always very laborious method of measuring the flow of water.

After a period of active investigations, which shall take up in turn the different mountainous regions, the corps can be gradually reduced to a single central bureau, which shall collate and publish amually the results of the observations made, and revise periodically the general inventory of hydraulic force.

Annual publication of results.- The annual publication of observations, measurements, hydrologic researches, etc., should be regarded as essential, for this will bring to the knowledge of persons and communities who contemplate utilizing the streams a collection of facts of continually increasing interest.

Having in mind these general considerations, we have been led to divide this report on the work of the burean into several chapters and appendices, which treat each special topic separately, as follows:

Chapter II.-Stations for gaging volumes of water.

Chapter III.-Measurement of rainfall and snow.

Chapter IV.-Description of drainage basins.

Chapter V.-Surveying.

Chapter VI.-Publications.

Moreover, the appendices contain a number of documents concerning various special questions, such as measuring instrunents, the first tentative census of hydraulic force, the organization of this work abroad, the theory of volume measurements in streams with changeable beds, typical formulas, photographs of various instruments and appliances, etc.

\section{COMMITTEE OF SCIENTIFIC INVESTIGATION.}

By a decree of March 31. 1905, a conmittee composed of scientific agriculturists, scientists, and engineers was created in the ministry of agriculture as a part of the division of hydraulics and agricultural 
improvements to make a study of the various questions of interest to the bureaus in this division. A second decree of December 26, 1905, increased the membership of this committee from 14 to 24 and widened the scope of questions to be studied.

Some of these questions are allied to the subjects treated in this paper, such as the general geologic and statistical study of underground streams, surveys of river profiles, the experimental determination of the value of coefficients used in the formulas for the volume of canals, the study of glaciers, and the study of rainfall and snow.

\section{LAWS AND REGUIATIONS FOR REFORMING SYSTEM OF LICENSES AND PERMITS FOR HYDRAULIC POWER PIANTS.}

The French regulations take cognizance of two kinds of streams(1) rivers that are navigable neither for vessels nor for rafts, over which the French minister of agriculture exercises certain police powers and in which the riparian landowners possess certain rights; (2) streams that are navigable by ressels or rafts, which lie within the public domain and which are administered by the minister of public works.

It should be added that the conduits used for the transmission of clectric power, which constitute an essential part of hydraulic distributing plants, are placed mainly under the control of the minister of public works.

The report of 1900 , referred to on page 12, attracted the attention of the French Government to the insufficiency of the existing legislation on the evolution of the new "white coal" industry, and the minister of public works and the minister of agrieulture prepared a bill which they presented to the Chamber of Deputies July 6, 1900. The principal object of this bill was to make all hydraulic power plants of more than 200 horsepower so-called "publie" plants, and under its provisions large plants for the industrial utilization of streams could be built only after a license had been obtained for a limited period by petitioner's considered to be the best among those seeking this privilege; that is to say, the petitioners who offered the greatest advantages to the community.

The bill of 1900 , which guaranteed to the nation the control of all large hydraulic power plants and retained for the Government complete control over the future development of the various publie utilities, aroused vigorous protest from manufacturers, who wished these plants to retain the character of purely private enterprises, and, above all, from certain intermediaries, who, having speculated in future riparian rights, were threatened with the entire loss of their possible profits if these large plants acquired the character of "public" concerns. 
The opponents to the bill had in mind mainly those streams navigable by neither vessels nor rafts, along which property owners enjoyed certain rights. They succeeded, in 1903, in obtaining consideration of a new plan for revising the existing laws, a plan which had reference exclusively to streams of this character. A bill was proposed on behalf of the Government, January 15, 1904. by M. Mougeot, minister of agriculture. During sereral sessions of the legislature this bill was investigated and resulted in a report presented to the Chamber of Deputies on February 21, 1908, by M. Lebrun. ${ }^{a}$

Another proposed law, relative to the establishment of power plants on watercourses navigable by boats or rafts, submitted by the minister of public works, has been reported on by M. Baudin ${ }^{b}$ to a competent committee of the Chamber of Deputies.

In Italy, after extended controversy, and after a series of laws had been proposed and rejected, there was presented to the Senate on December 15, 1908, a simple text of law providing for cooperation between the ministers of the interior, agriculture, and commerce and labor.

In Switzerland several Cantons have, since 1899, modified their legislation. These modifications, together with the results of exploitation of the principal hydro-electric installations, were discussed in $1906^{\circ}$ by M. Reuss and M. Cordier. The discussion gave special consideration to the new law of the Canton of Berne, which in 1906 was still in process of revision. Subsequently this process was completed and on May 26, 1907, the law was submitted to popular vote and approved.

Without going into the details of the controversies to which this long discussion of legislative reforms has given rise, it may be useful to explain in the most general terms the nature of the conflict which has arisen between manufacturers and engineer's."

a Portions of this report, together witl proposed law, appears on $\mathrm{pp}$. $74-85$.

${ }^{b}$ Portions of this report, together with the proposed law, appears on pp. 85-92.

${ }^{c}$ Annales de l'hydraulique et des améliorations agricoles, fasc. 34, pp. 189-308.

${ }^{d}$ References to these discussions appear in the following papers:

Les forces hydrauliques des Alpes-leur rôle économique, leur avenir. Rapport présentê à la Société d'économie politique de Lyon, par René Tavernier, ingénieur en chef des ponts et chaussées.

Les grandes forces hydrauliques des Alpes. Rapport présenté à la sociétê d'études économiques de la Loire, par .M. Tarernier.

La houille blanche. Discussion du rapportt précédent.

L'utilisation des cluutes d'eau dans les Alpes françaises, par M. Reué Tavernier. Conférence à la Société des ingénieur's civils de la houille blanche, Grenoble, 1902.

Influence des neiges et des glaciers sur le légime des cours d'eau, par M. René Tavernier. Conférence faite au Congrès de la houille hlanche, Grienohle. 1902.

Etude hydrologique du bassin de montagne, par 2I: R. de la Brosse, ingénieur en chef des ponts et chaussées. Conférence faite au Congrès de la houlle blanche, Grenoble, 1902.

Législation des chutes d'eau, par M. Ch. Pinot, ancien ingénieur des ponts et chaussées.

De l'utilisation des forces hydrauliques. Citudes des modifications à apporter à la législation existante. Société d'études législatives, Nos. 1, 2, 3, et 4.

Etude de géographie humaine. Lirrigation. Ses conditions géographiques, ses modes et son organisation dans, la péninsule et dans l'Afrique du Nord, par .I. Jean Brunhes. Compte-rendu par M. René Tavernier. (Annales des Ponts et Chaussées. 1903, 1er trimestre.)

La richesse du 'Rhône et son utilisation. Rapport présenté à la Société d'économie polltigue de Lyon, par' M. René 'Tavernier. 
The manufacturers argued as follows:

We provide, on most favorable terms, the power needed by important public utilities. The greater the liberty accorded to us the better' we will perfor'm this task, for then it will be easier for us to bring together a large number of power-producing plants, which supplement each other in supplying the public utilities, whose needs are both intermittent and exacting.

To this the engineer's made the following answer:

This plan is an excellent one, and entirely in conformity with the economle neels of the "white conl" industry ; but, if the underlying principle is carried to its nltimate consequences, as must lappen sooner or latel, it will lead inevitably to a monopoly in ench region, or perhaps to a national monopoly.

Possibly large-scale industries might be able, at least in the beginning and as long as there are still any waterfalls to be utilized, to get along in spite of this monopoly, although it seems singularly dangerous to place forever in the hands of a few persons the control of what is in reality bound to become a raw material for all industries, large or small. A small plant, inevitably tributary to the monopoly which distributes power in its particular region, as well as public utilities like illumination, transportation, and irrigation, all of which are necessarily localized, would manifestly be in no position to discuss the prices asked for furnishing power, when this power is furnished by the "white coal" trust. There can be no doubt that the monopolistic exploitation of this source of power, if completely unhampered, will be able to provide private concerns, as well as public utilities, with the energy needed at the lowest price. It must be asked, however, to what extent will these "masters of the market" be disposed to share with their obligatory customers the savings which they effect in the production of power. The experience of the past furnishes an answer to this question. If we judge all the old practices of gas companies, adhered to until electricity became a competitor, the prorlucers who enjoy a monopoly have heretofore scarcely evel applied rational methods of fixing charges by lowering prices to those who are unable to pay high prices while at the same time charging higher rates to other consumers. Almost always they have preferred, whenever they were given the ehoice, to make their profits by selling small quantities at high prices rather than by selling large quantities at small prices. It is, of conrse, possible that the concerns for the distribution of "white coal" power will constitute a happy novelty, and that they will understand their own interests better than the gas companies formerly understood theirs. No one, however, can regard as superfluous the methods by which the proper branches of the Government may constrain a monopolistic corporation producing hydro-electric power to adopt a policy of management which will insure the greatest advantage to the business community at large. 
At the present time none of the bills concerning the establishment of hydraulic power plants have been passed. The Government is therefore obliged to carry on this work upon the basis of existing law. We shall indicate in the following paragraphs what the minister of agriculture has been able to do in certain special cases in regard to irrigation.

With regard to the means for transporting: electricity, however, very minute regulations have been enacted. The law of June 15, 1906, has been followed by several decrees governing the details of their enforcement. The principal decrees are the following: That of February 7, 1907, creating a permanent governing committee on electricity; that of October 17, 1907, organizing the supervision of power-distributing plants; that of April 3, 1908, supplementing the fundamental features of the law of June 15, 1906; that of August 20, 1908 , providing for a standard set of specifications.

The organization for supervising the electric transmission, dealing with technical questions affecting public security rather than with the commercial problem of lowering prices, is of too recent date to justify any conclusions with regard to its possible advantageous effects on irrigation in particular.

\section{SPECIAL STUDIES MADE BY MINISTER OF AGRICUL- TURE.}

The possibility of using the hydro-electric power for irrigation comes up in a peculiar form in the valley of the Rhone, in all the lateral valleys bordering on the Alps, and in the south western parts of France, which are watered by streams rising in the Pyrenees.

The regimen of streams flowing from the Pyrenees is influenced by numerous lakes, whose utilization has been systematically planned by the minister of agriculture for a number of years. It is evident that these works, originally planned for the specific purpose of reinforcing the supply of water for the streams flowing out of the tableland of Lannemezan, will also have a beneficial influence on the hydraulic power systems of the ralleys that are concerned. The lakes are sifuated at very high altitudes. Their utilization will create intermittent power, which at certain times may be valuable for irrigation. If the agricultural department will not use it directly, it will at least obtain from those who profit by it a compensation which can not be better used than for the extension of irrigation.

In the basin of the Durance the problem of reservoirs is no less interesting than in the Pyrenees, but its solution is more difficult. Sites for reservoirs of large capacity have long been found and examined on the Durance itself where it joins the Ubaye, as well as at different points in Verdon. Such reservoirs could be used to 
counteract the disastrous shortages of water experienced in some years by the large irrigation channels supplied by the Bassa-Durance. It is to be hoped that these reserroirs will soon be constructed. Then the Government, which will reinforce by large reserve supplies of water the hydraulic system of the Durance, the main source of power for the entire sontheaster'n part of France, will be in a position to obtain at low prices from the power-distributing companies who profit by this state of affairs the power needed for irrigation.

Nowadays the system of licenses still in vogue on streams included in the public domain (the Durance is classed as navigable by rafts throughout most of its length, from Embrum to the Rhone) enables the division of agricultural hydraulics to obtain from the motive power of the lower Durance large quantities of hydro-electric power taken at the generating plant for very low prices, varying according to the periods of delivery from 0.01 to 0.015 franc ( 2 to 3 mills) per kilowatt-hour.

One important question which is now being studied will provide an opportunity for the bureans connected with the division of agricultural hydraulics to deal adequately with the question of furnishing at low prices the power needed to pump water for irrigation. The question arose in comnection with a large undertaking to irrigate the low plains sitnated on the right bank of the Rhone near Nimes and Montpellier. In $18 \pm 7$ Aristide Dumont, engineer of bridges and roads, first suggested diverting from the Rhone 25 cubic meters (883 cubic feet) a second for irrigation.

After numerons modifications the programme finally adopted in 1897 consisted in building three independent diverting channels discharging a total of 1,660 cubic feet (47 cubic meters) of water. The total cost was estimated at $\$ 3 \pi, 600,000$ (188,000,000 francs). The plan was to be carried out as soon as there were enough pledges for the irrigation to require a total of 1,060 cubic feet ( 30 cubic meters) discharge. The water was to be sold to the cities at a continuous flow, at the rate of 1,000 franes per liter per second, ${ }^{a}$ and for watering purposes in intermittent supply at the price of 63.50 francs per liter per second ( $\$ 1.50$ per million gallons at about 50 cents per acrefoot).

This vast undertaking has stirred up public opinion for fifty years and has given rise to sharp controversies which may be found in the report of the writer on "The wealth of the Rhore and its utilization."

There were two parties to the debate, one side representing the interests of navigation and the other the farming interests. The

a Equivaleut to about $\$ 5.700$ per second-foot of constant 1 low, or about $\$ 8$ per acrefoot per year, or about \$2ut per million gallons per year. 
failure to carry out successfully the programme of 1897 , moreover, is due less to the opposition which it encountered than to the impossibility of obtaining the number of pledged subscribers for the use of the water that was considered indispensable for the successful operation of the enterprise.

To-day it seems that, thanks to the installation of hydraulic power plants, these old quarrels are about to die out. The question of the Rhone irrigation channels, stirred up by the dolorous and disturbing erisis in wine production which is now being felt by the sonthern part of France, is being so modified as to bring us nearer to a solution that will harmonize rather than accentuate divergent interests.

A recent decision of the minister of agriculture has intrusted the writer of this paper with the task of devising an irrigation system based on the pumping of water taken from the lower Rhonc. 'The most important part of this investigation will consist in finding how to furnish power at the lowest price for the pumping stations, either by compelling the future holders of licenses for hydraulic plants to concede specially low terms, as has already been accomplished in connection with the motive-power syndicate of the lower Durance, or, if it should prove necessary, to elaborate a complete plan for the erection of an entirely new series of plants for furnishing power to all the concerns that might need it in the region under consideration.

\section{CONCLUSION.}

The United States of America, at least in the opinion of those who, like myself, are yet unfamilar with the country, is par excellence the land of great business enterprises, because of wonderful personal initiative, the power of large masses of capital, and the intensity of local life due to the economic independence of the sereral States. I am sure that these elements will play an important part in the exploitation of the hydraulic wealth upon which is so largely dependent the development of such regions as the one in which this congress is being held [Albuquerque, N. Mex.]. But I have also noted, with equal gratifieation, the powerful cooperation in the development of water power that is being provided by the Federal Government through the Departments of the Interior and of Agriculture, without which isolated and independent enterprises would run a great risk of failure. The marvelous work of the Geological Survey and of the Reclamation Service is too widely known to require any word of praise from me at this time and place. But I wish to draw one inference from this general phenomenon of the increasing intervention of the central Government. We appear to be gradually recognizing more and more fully that hydraulic wealth is 
a collective wealth liable to be wantonly wasted if it is not used cooperatively. If water, which has so long divided mankind, seems now about to bring them together for the common good; if there is to be harmony between interests which long have been antagonistic-all of which miracle is to be wronght by the fairy named Electricity-it will everywhere be necessary for a final tribunal to intervene on behalf of such harmony in the interest of the community, regardless of administrative and political boundaries, with which hydrologic phenomena have no concern.

A profound conscionsness of this new sort of interdependence has given rise to the measures that are being taken in France by the minister of agriculture to enable irrigation to benefit by the utilization of hydraulic energy. 
CHAPTER III.

FRENCH AND FOREIGA LEGISLATION RELATIVE TO THE DEVELOPMEN'T OF WATER POITERS.

By René Tavernter.

\section{PRACTICAL UTILITY OF THE STUDY.}

It is not purposed to discuss water-power legislation in France, Italy, and Switzerland from the point of view of the lawyer or the historian. The simplest analysis of the voluminous treatises that have been written on the subject in the three countries would require too extended space. Most of the anthors of such treatises are lawyers who have been inclined to study the past; when considering the future they have endeavored to preserve the old traditions, even in the most modern application. Practical men, on the other hand, who desire a quicker development of the industry, try to accommodate themselves as well as possible to the antiquated laws rather than endearor to institute a reform and have the laws corrected, dreading the intervention of the Government and fearing to avail themselves of its almost indispensable cooperation, lest they provole undesired interference.

It is difficult to imagine a greater disparity than exists between the character and scope of the present. French legislation and the actual state of affairs with reference to water-power development. The necessity for bringing these laws into harmony with present conditions has been generally recognized, and it has been shown that the requirements imposed by these ancient laws are insecure and transitory. We need not enter into an investigation of Roman or feudal law to find the origin of the present law with reference to watercourses. It will suffice to state that in France watercourses that are navigable for neither ships nor rafts belong to the owners of adjacent lands; in Switzerland control is retained by the Cantons and communes; ${ }^{b}$ and in Italy the waters are public property, concessions for development being issued by the Government.

\footnotetext{
a translation of chapter 3 of M. Tavernier's report, made in 1900, "1.es forces hydrauliques des Alpes en France," referred to on p. 12.

"The Canton of Switzerland corresponds to the State of the United States; the commune corresponds to the county. Since this report was witten the control has passed to the Federal Government.
} 
Before the introduction of electricity water powers were employed only on small tracts of land bordering the watercourses, but recent progress in electric transmission has made it possible to extend their use over wide areas. Whereas formerly an application by a riparian owner for a license to use water, either for irrigation or for a mill, meant only that he would use the water for specific purposes on his own property, now the use of water power has entered a new field and new financial benefits are derived from it. Consequently new laws and regulations have become a neeessity.

\section{FRENCI IEGISLATION.}

\section{LAWS AND REGULATIONS IN FORCE.}

Applications for the establishment of power plants along nonnavigable watercourses in France were, by circulars of October 23 , 1851, December 26,1884 , and March 2, 1898, made subject to certain regulations. Nore recently the administration of watercourses has been made the subject of a law. promulgated April 8, 1898, article 12 of which anticipates the enactment of a new law providing for broader public control than that afforded by the circulars mentioned above. It shonld be stated, in connection with subsequent quotations of certain passages from the work of M. Delbet, that the legislation of 1898 has not settled the question of the ownership of power privileges and has not bronght thereinto any new principle. The ownership of the river beds by the riparian proprietors is conceded, and there is no separation of the power sites from the watercourses in general.

This law, promulgated after consideration of the matter during a period covering nearly a century, shows a very plain disregard of modern needs and requirements. It is said that the Chamber of Depnties wished explicitly to give to the riparian owners on the watercourses the control of power privileges. To this the Senate was opposed. In this connection, M. Delbet, deputy, in his report of July 12, 1897, says:

The proposed law does not deal directly with the ownership of waterfalls not actually opeliated. The commission of the Chamber in 1888 wanted especially to prevent any encroachment by the Government on the rights of private property and the alditraly disposal thereof. The commission thought that a special law covering this point could be framed after its utility had been proven; but, as it was of importance not to retard any longer the vote on this paragraph of the rural cole, consicleration of this matter of comparatively small importance was omitted, in order to aroid a new discussion that probably would have resulted in the failure of the entire measure through monconcurrence of the Senate.

It seems impossible to modify the rules defining government intervention in matters of power-plant regulation without creating a 
new law. Such intervention, if reduced to a minimum, would fail to effect necessary reforms.

\section{JURISPRUDENCE.}

The Government does not intervene in an ordinary disagreement unless it becomes necessary to protect the riparian owners from damage to or infringement of their water rights. To make such intervention perfectly legal, broader powers should be assumed. Indemnity for private damages and the defense of private rights are adjudicated in the lower courts, except where the rights of third parties are involved. In spite of many commentaries, circulars, and decrees specifying the scope and application of the law, the limit of administrative power has always been most uncertain. Engineers are greatly embarrassed by the opposition encomtered in their work. They frequently have to act as intermediaries between opporing parties for the purpose of settling disputes ont of count. 'The Government does not, as a general rule, concern itself with the verification of the petitioner's claim that he owns the necessary tract of land; it does not even specify the amount of water permitted to be withdrawn. Consequently the privileges actually granted may be utilized only in part, or not at all, and the nation has no right to interfere. Neither does the Government concern itself with isolated claims for damages inflicted on downstream owners by upstream. diversions. There results, in effect, confiscation of the property rights of the greater number of people for the benefit of the fewer, and this is made more serious by the fact that the right, as created under the water regulation, is perpetual and without a forfeiture clause.

Few real difficulties are encountered with such a law so long as it applies to the short diversions established by owners of rights within their own property. The right to a waterfall created under this law is, in effect, an extension of the general right of ownership in the water and, like this general right, it is perpetual and absolute. It is singular that such an extension of the administrative permit appeared necessary. It would have been more logical to vest the ownership of the waterfalls specifically in the owners of the banks, as was at first intended by the legislature of 1898. M. Picard explains why this was not done. ${ }^{a}$ The reasons were as follows: First, the slope of the river bed between the limits of the property of a single owner is not, in most places, sufficient for the development of power necessary in the operation of a plant of important size. Furthermore, it would be very difficult to induce the bunk owners to combine their partial powers and thereby create a common power susceptible of development and utilization to the profit of the whole 
community or of one of the members thereof. The resistance of one riparian owner would be sufficient to render the resource unavailable, to the great detriment of the public interest.

Accordingly, for the reasons set forth, the legislature of 1898 explicitly refused in all cases to unite the ownership of the water with the ownership of the banks. And so, legally, under the new law, the actual water itself is nonexistent (res nullius), although, as in the past, it is subject to private appropriation by the person who first makes application for an administrative permit to make beneficial use thereof.

\section{DEFECTS OF THE PRESENT LAW.}

Under present conditions the difficulties encountered in the development of hydro-electric plants are almost intolerable. An installation of such character generally involves the diversion of the total lowwater flow of a river for several miles along its course. It affects the interests of hundreds of persons, including the owners of lands crossed by conduits or occupied by the plant as well as the owners of the river banks. The founders of the great hydro-electric power plants in Isère and Savoie did not at first apply for government license; this they did after they had quieted all objections by procuring the necessary bills of sale, contracts, and other legal documents. But this practice is no longer effective, because the landowners are becoming conscious of the value of the water power's and are less easily persuaded to part with their rights than formerly; also becanse the benefits that have been realized have given rise to an outburst of speculation. A new class of speculators, properly called obstructionists, has appeared. These people, by purchasing a few lots at different places, control the situation and completely prevent water-power development unless the promoting interests accept their terms. As a result of this, it frequently happens that power sites of first choice have to be abandoned for less convenient but more easily attainable ones. If one considers the enormous capital invested in electro-chemical and electro-metallurgical industries; if one knows, on the other hand, the importance of transmission to the industries which would, without it, be compelled to locate at great distances from their supply of raw material and far from their market; and if, finally, one takes account of recent happenings along this line, he can not but perceive that there exists a condition of chaos and dissatisfaction. Such practices are destructive of public confidence, public morals, and general public economy. Considered even from the standpoint of private initiative, they are as pernicious as are the laws that make them possible, but when public interest and the duty of 
the nation are considered the reproaches that may be cast on the law are very forcible.

The Government should intervene in the interest of public safety. It should regulate the construction and operation of all reservoirs and conduits. The failure of such structures, exposed as they frequently are to high pressures induced by great hydraulic heads, is liable to cause great loss of life and destruetion of property. A second reason for government intervention is that, before granting a new concession and thereby creating a new right, which covers all the previous rights but which constitutes a sort of special right, the Government should satisfy itself that the applicant for concession, whom the outsider is powerless to oppose, is, in reality, capable of installing and operating the prospective works. It is a question of public morals and also one of general economy. A third reason for government intervention is that it is highly desirable that the industry which has acquired a right by purchase from intermediaries, who sell to their advantage a right to water power created by administrative act, shall be protected against the possibility that the title to the property shall be clouded by the appearance of some accidentally forgotten owner, who will create disturbance by subsequently selling his interest to some adversely disposed person. This does not apply to small developments but to hydro-electric power plants which represent a large outlay of capital. It is often the case that, at an unexpected moment-thanks, it is said, to the comnivance of the administration-the integrity of such an investment is compromised by the appearance of old claims. From considerations of general economy and of public interest it is intolerable that the capitalization of so valuable a natural resource shall be held in check by so many obstructions that in certain cases even the appurtenant works necessary to the completion of the development can not be established, in default of the necessary ground.

To avoid all these abuses without modifying legislation it would be necessary for the administrative authorities to subject the proposed projects to a minute examination, to satisfy themselves that all necessary preliminary arrangements are made, all necessary lands purchased, and all rights acquired. It is believed that even such precautions would not be entircly sufficient, because even where all such provisions were fully complied with, the administration would still be without power under existing law to force the grantee of the right to utilize the water power to its full capacity and in a rational manner. The existing law does not fix the amount of water to be used, and it makes no stipulations except a time limit placed on the construction of works and provides no forfeiture for nonoperation of the works and nonutilization of the water. In other words, the adminis- 
tration creates an unlimited and exclusive right to a resource, without even imposing on the grantee the obligation of using it and without giving to him the means of so doing, if he meets with opposition from outside parties.

In all the preceding critical analysis, the intervention of the nation has been regarded solely from considerations of the security of public interest in respect to water rights and of the principle that the nation should not abandon control of the natural resources without at least imposing the obligation of their utilization. It is undeniable that on all these points the laws in force do not permit the administration to exercise such absolute control as we have pointed out.

The method of utilizing water power will now be considered. Under existing law a holder of a concession for light and traction may endeavor to acquire also a concession for a power plant and for some industrial establishment. As the interests of two such persons in the same region may clash, it may occur that both parties are defeated in their purposes, or that one is favored at the expense of the other. Vast public interests may be damaged in this way, and work of the greatest importance may be frustrated. There is no legislation at present to remedy this condition. In fact, the intermediaries who exploited the first water powers in the French Alps were not coneerned with enterprises of public interest, and it will be recognized that, on account of the poverty of the people in the region in which they are located, such enterprises can not be immediately productive of the greatest benefits.

In examining the list, set forth in statistical tables, of the large hydro-electric developments recently established in France, in Switzerland, and in Italy, one can not but be impressed with the great and characteristic differences in the uses to which water power is put. In France the great. developments are largely private and are devoted to electro-chemical and electro-metallurgical industries. In Switzerland and Italy the developments are great public enterprises engaged in the transmission and distribution of power in the open market for traction and other purposes. This is due, no doubt, in part, to the fact that the French Alps have a smaller population and fewer industries than have the Sriss and Italian Alps; and in part also to the insufficiency of French legislation.

\section{PROPOSED REFORMS.}

The difficulties encountered under existing law, on the one hand by those who are trying to operate large water powers and on the other by the government representatives charged with the application of apparently inapplicable and insufficient laws, having been summarized, it is now incumbent on us to show what reforms are proposed. 
The first and principal reform should consist of the substitution of concessions ${ }^{a}$ or franchises in place of the present license or mere permission. These concessions should be limited to a specified time and to a specified hydraulic power. They should include the usual clauses of redemption and forfeiture, although they need not necessarily confer upon the grantee the right of expropriation, resort to which in each case should be determined by its effect on the public interests, present and future.

The granting of concessions only for the large enterprises and the continuing to issue permits for the smaller powers will quiet the apprehensions of those who persist in considering the water powers as private property, or at least as a natural extension of private property. Such owners say, "If a fall is entirely on my property, if I am the owner of both banks, why should the Government oppose my using the water at my convenience, provided I return it at the boundary of my grounds, in compliance with article $6+t$ of the civil code? If a number of owners should unite and transfer their rights to an individual, how could the Government refuse to that individual the same rights it grants to the original owners? [Referring to simple permits.] Is it not extraordinary that it should claim to have the right to enter upon private property and place there, for the development of power, a concessionnaire of its own choice?"

The premises upon which these arguments are based are incorrect. The proprietor of both banks of a stream is not refused the right to develop the water power; on the contrary, he is denied the right of not using it. In fact, in the development of water powers, as in all other enterprises susceptible of being considered public utilities, the private citizen is freely allowed to realize a profit from and on his possessions. It is not intended to crowd out the little owner and to prevent him from using the small privileges for his small enterprises. It appears necessary to reconcile the opposing views and to preserve, in genera], the system of granting permits for water powers of less than 200 horsepower, while the larger powers, which are destined to play a great part in the public economy, shall be regulated under concession, with an accompanying decharation of public utility. I special precantion shonld be taken in every case; the concessionnaire ought to prove the general utility of his enterprise, and the smaller mills should not be permitted to interfere with large developments and thus diminish their usefulness to the public. The best plan would be to permit the small mill to exist by the side of the large plant and to have returned to it, in the form of power, the equivalent of that which the larger plant takes in the form of water.

${ }^{a}$ The French word concession seems by this and subsequent context to be identical with what is commonly known in this country as a lease. There may, however, be a sllght difference between the two, Therefore the former term will be used in subsequent pages. - M. O. L. 


\section{PRINCIPLES PROPOSED FOR BASIS OF NEW LEGISLATION.}

The ideal solution consists in permitting all the interests, private as well as public, to develop power, and in considering according to their respective merits, several applicants who seek to obtain concession of the same power site. Such is the policy upon which the following general principles are based:

1. All the various lines of water-power utilization must be facilitated and encomraged simultancously, because the water powers are concentrated at certain points in such enormous quantities that there is no risk of their speedy exhaustion; further, because, for technical and economic reasons, it is of the greatest advantage to distribute the power prodnced among the greatest passible number of uses.

2. The engineer's of the Government, of the provinces, and of the comties, as well as those representing private interests, must be free, and even encouraged in special cases, to make studies and propose methods for making the best use of water power.

3. The power of concession must belong to the State [that is, the National Gorernment], which alone is able to combine all available information and to settle difficulties arising among opposing interests. Such power should be exercired irrespective of all financial influences, in the sole eflort to derive from the exploitation of public resources the greatest possible amount of benefit. When there is no general public interest that woukl be damaged thereby, concessions shall be granted, with or without a clanse of retrocession, in the following order of preference: First, to the province; second, to the county; and third, to a company making application therefor.

4. The duration of a concession shall be limited to the shortest possible term, in order that any mistakes or defeets in the regulations may be corrected and that changes may be made to conform to changes in conditions. Among such possible modifications, the most important will undoubtedly be the adoption of electric traction by large railway systems.

5. The acknowledgment of speeial rights of any person or privileges in water powers should be guarded against. Neither the exclusive right, granted provisionally in France to riparian owners or to intermediaries to whom such owners have conceded their rights, nor the right of prior application, recognized in Italy, subject only to the higher interest of the Government, is an acceptable standard. The highest duty of the Government in the matter of water power, as in the matter of railroads and street railways, is to follow that course which will give to the public in general, and especially to the neighboring populations, the greatest advantages.

The chief characteristics of such legislation as we believe desirable having been outlined, it now remains for us to study the matter 
in detail and to formulate the precise language. Before doing so, it will be useful to analyze and set forth certain characteristic points in Italian and swiss legislation.

\section{ITALIAN LEGISIATION.}

\section{CLASSIFICATION OF WATERS.}

Industrial diversions, like those for agricultural purposes, are regulated in Italy by the organic law of August 10, 188t, regulating the diversion of public waters."

First let us consider the designation "public waters." Are all the natural watercourses, even the very small ones, covered by this law? This appear's not to be so, because article 25 provides for a "classification" of the "public waters" of the nation." Nevertheless, it would appear proper that this term should comprehend all large watercourses that are susceptible, by reason of the volume of their waters or the extent of their courses, of serving public purposes. This, of course, includes lakes and watercourses made navigable or improved by national subsidies. Such waters are subject to the control of the sovereign, while the other watercourses come under that of the prefect. There is disagreement among the lawyers as to the classification of "public waters," and also as to the nature and importance of the domain rights of the nation. According to some, the public wateis are a part of the public domain; and, according to others, they are a part of the private domain of the nation. (See Pacelli, Francesco, Le acque pubbliche: Report of the commission created by decree of August 16, 1898.)

For the diversion of "public waters" a "concession" from the Government is required, such concession being granted in virtue of the payment of rent (article 1).

\section{DISTINCTION BETWEEN "CONCESSION" AND "AUTHORIZATION."}

It is interesting, in connection with article 1, to note a passage from the work of M. Pacelli, cited above, which compares the French and Italian legislation and treats of the distinction to be made between the "authorization" of the French system and the "concession" of the Italian system:

140. There has been formulated in France, specifically in the matter of public waters, an important distinction developed in Italy within recent years in an able monograph by Rinelletti-the distinction between a concession and an

a A Fench translation of this law is inserted in the Pulletin de l'hydrauligue agricole, Q. 6 , p. 126 .

- The attitude of the ltalian administration concerning the execution of this list is set rorth in a circular of the minister of public works of lebruary 6,1885 , in which is accepted the theory that very small watercourses are not a part of the public domain, 
authorization. The former recomnizes the creative function of the nation: it gives to the concessionnaire a new right-a right which he can acquire only by asking for it. The latter recognizes the activity of the nation as a guadian; it consists in remoring certain obstacles in the way of private activity; it permits the exercise of a right that existed in substance previous to the application. ${ }^{a}$ This distinetion was made in France for the purpose of reconciling the ciril code with the administrative legislation relative to the waters. It has been explained that the anthorization is suflicient for nomnarigable fratercourses where the riparian owners have a right of usage in virtue of article 644 of the code of Napoleon, and that a concession is required for navigable watercourses, which are expressly exempted from the provisions of that article. This distinction, accepted almost universally, * * * was applied in Belgium in the law of May 7 . 1ST, relative to nomnavigable watercourses. * * *

141. In Italy the distinction between concessions and authorizations in the matter of flurial domain is accelted by those who endearor to reconcile article 543 of the ciril code with the law relative to public works; they contend that a coucession is necessary in the case of rivers ant torrential bodies of water, and that an anthorization is sufficient for the other watercomrses of less importance. In my opinion, contending that a complete separation must be maintained between the waters regulated by the civil code and those regulated by administrative laws, the distinction is not applicable in Italy to the matter of public waters. According to my judgment, the fact of being an owwer of the banks of a public watercourse, large or small, implies no right of usage, and I contend that article 543 of the code applies merely to small private waterconrses. A concession will then always be necessary to vest in an applicant a - right of usage, in which he previously had no interest other than the possibility of procuring it by alplication.

After this theoretical digression, we will now return to the analysis of the law of 1884 .

\section{ANALYSIS OF THE LAW OF AUGUST 10, 1884.}

The papels of the concession fix the quantity of water to be alirerted, the conditions of diversion, withdrawal, use, and restoration of the waters, the rental, etc.; they also stipulate the requisite guaranties in faror of agriculture, industry, or public health. 'They fix the period within which the water must be diverted and used, under penalty of forfeiture. (Article 4.)

I concession call not be granted for a period in excess of thirty rears, but it is renewable in faror of the first concessionnaire for new periods of thirty years unless he, in the opinion of the administration, has attained the purpose for which the concession was granted to him. (Article 5.)

The concessionnaire is at liberty, under certain conditions, to change the purpose and equipment of his plant. (Articles 6 and 7.)

a Following that theory, the system of authorizations or permits should not be applied in France to industrial divelsions, since the legislature refused expressly to recognize in the riparian owners any right to "the falls of water." We have, on the other hand, long insisted on the inconveniences alising flom the creation of a right by means of a simple authorization or permission. 
Formal official instructions relative to concessions are regulated by articles 8 and 9. Certain prescriptions relative to security, closing of gates in times of floods, etc., are treated in articles 10, 11, and 12.

If, during the period of the concession, the regimen of the watercourse is changed in the public interest, the nation is not held to any indemnity in faror of the concessionnaire, who in such event has a right merely to a proportionate reduction in or cancellation of rental. (Article 13.)

Article 14 fixes the rental-3 franes (abont 5.) cents) per horsepower in industrial diversions. Articles 15 to 19 prescribe certain exemptions or certain details of collection of taxes. Articles 20 to 24 establish agreement with other laws.

Article 25 relates to the making up of the "schedules of public waters" previously mentioned.

Articles 26 and 27 relate to the malking up of a register of " diversions of public waters," compiled from the "declarations" of interested parties.

Article 28 provides that the details of the excution of the latw shall be determined by a public administrative regulation.

PUBLIC ADMINISTRATIVE REGULATION OF NOVEMBER 26, 1893.

In execution of article 28 of the law of August 10, 188t, the first public administrative regulation was promulgated on November 9, 1885 ; but it quickly became insufficient and was replaced by a more complete and modern regulation November 26,1893 . 'This new regulation added to the law two new principles which had not previonsly been recognized and which were rendered necessary by the zeal of speculation brought about by profitable water-power derelopments(1) the principle of preference in favor of the first applicant for concession in cases where concurrent applications technically can not coexist (article 8); (2) the principle of the higher rights of the nation, which may, in the consideration of public interest, either oppose an individual application (article $\tau$ ) or accord the preference to one of the later applications among a number of concurrent applications, in derogation of the principle first established.

\section{CIRCULAR OF JUNE 17, 1898.}

The interpretation of these two principles and their application by Gen. Afan de Rivera, minister of public works, in his celebrated circular of $\mathbf{J}$ une 17,1898 , in which he charged all prefects, engineers, etc., to deny all applications for powers that might be utilized for electric traction on the large railroads. aroused and still arouses lively discussion in the technical and industrial world of Italy. The directors of the Compagnie fermière du grand reseau de l'Adriatique 
entered into a vigorous controversy with General De Rivera on certain technical questions in the Nuova Antologia of June 15 and August 1, 1898. They seemed, however, to share his opinion as to the necessity of preventing a monopoly of water powers, in view of the adoption of electric traction, and as to the importance of electric traction for mountain lines with small traffic.

\section{REVISION OF THE LAW OF AUGLST 10, 1884.}

In response to various expressions of dissatisfaction a decree of August 16, 1898, named a commission for the purpose of reforming the law of 1884 . The terms of this decree are as follows:

(a) To establish rules and limitations of concession for diversions of public waters, either for electric traction of railways or for other industrial and agricultural purposes of no less importance in the social economy.

(b) To devise administrative regulations for the prevention of speculation and monopolies and changes in the objects of concessions sranted.

(c) To formulate, in the spirit indicated in $b$, modifications that might desirably be incorporated into the laws and regulations in force.

\section{SCOPE OF THE PROPOSED NEW LAW.}

The new text proposed by this commission introduced into the law many of the regulations of 1893 and, more particularly, the two principles alleady mentioned $(\mathrm{pp} \cdot 46,4 \tau)$, which are fully explained and commented on. It modifies, moreover, the competency, nature, and method of renewal of concessions, the determination of rentals, and certain details of administrative procedure, which are of no special interest, except in connection with the Italian administrative organization, which is slightly different from the French.

Below are given explanatory summaries of each of these points:

1. Principle of preference in favor of first applicant. This principle, supported by article 6 of the regulation of 1898 , is retained in almost the same terms in article 5 of the proposed law:

Whenever two or more applications are made, in the prescribed form, for all or a part of the same concession, and the several interests represented can not all be served in common, concession shall be glanted to the application first presented.

This rule is subject to derogation when predominating public interests militate in favor of some later application, presented less than a month after the expiration of the term named in the decree of publication of the first application.

The reasons brought forward must be submitted to the examination of the administration and to committees appointed to give adrice on applications for concession. 
2. Principle of according priority to the interests of the nation. The application of this principle is regulated by article 3 of the proposed law, as follows:

Whenever application is made for concession for a diversion of the first class, consideration thereof shall be preceded by an examination by a permanent special commission, to determine whether, irrespective of the application in hand, any legitimate public interest or any present or future need of the nation interferes with the granting of a concession. This commission is appointed at the beginning of each year, from members of the higher board of publie works, of the high committee on tariffs, of representatives, of the lighl legal counsel of the treatsury, and of ministers of publie works, of hinances, of agriculture, of industry, and of commerce, as well as of the war and nary. If the decision of said commission is farorable, the examination of the application in the regular mammer immediately follows. If the decision is unfarorable, the minister of public works shall, after consultation with the higher conncil and the conncil of state, render a decree deciding whether the examination of the application shall proced. By means of such a decree, the minister can, if necessary, nltimately prevent all concessions to individuals in a certain river basin, section, or lake orer which he has control.

If, in the interest of a public service, the nation finds it desirable to utilize, or to reserve, in any manner, water powers of one or another class, the competent administration, or a deputy nomed for that special purpose, shall present a preliminary plan containing a technical exposition of the purposes, nature, object, and utility of the work to be established or of the reservation. This plan shall be submitted ly the minister to the permanent special commission aforesaid, and in accordance with its advice and that of the higher board of mublic works, after consultation with the comncil of state, he shall decide by special decree the appropriation or reservation of the power privileges demanded for the public service. In ease of a farorable decree, all individual demands that can not techmically coexist, along with the project or the reservation of the Government, shall be denied, irrespective of the state of advancement of construction.

The decrees of the minister of public works are muassailable, the only reconrse against them being that provided by articles 12, 14, and 24 of the law for the council of state.

3. Changes in jurisdiction. According to articles 2 and 3 of the law of 1884 , jurisdiction was based on the character of the watercourse. A law was required in the case of a perpetual concession, a royal decree for those relating to lakes, livers, boundary waters, navigable streams, and watercourses whose embankments and shores are recorded among the hydraulic bodies of the second class, while the prefect decided in all other cases. According to articles 2 and 3 of the proposed law, on the contrary, the jurisdiction depends on the importance of the diversions, which are divided into two classes. The first class, for which a royal decree is necessary, corresponds to the "large diversions," the limits of which were fixed by article 1 of the regulation of 1893 , covering specifically all developments of power greater than 200 horsepower. The prefect has jurisdiction over all applications of the second class, except that where the application 
concerns a lake, a navigable watercourse, etc., he obtains authority from the minister of public works.

4. Changes in character and conditions of renewal of concessions. The principle of a thirtr-year concession, renewable indefinitely in favor of the first concessionnaire, with clauses of forfeiture but without clauses of redemption or return to the nation, is retained in the proposed law as it was laid down by the Italian law, but with certain modifications designed to prevent monopolies or to obviate making it irrevocably binding for all future time.

In order to reduce the chances for monopoly and speculation, article 1 of the proposed law stipulates:

The concessionnaire of a public water diversion can be anthorized by the decree of investiture to form either a syndicate or a civil or commercial comjany for the exploitation of lis concession. provided he remains connected with it up to the time of the orwanization of the company and provided that the organization is effected within a period of six nonths from the date at which the decree of investiture went into effect. 1 t is forbidden, under penalty of forfeiture, to transfer to a third larty a concession for the diversion of public waters in any other manner before such coneession shall have been entirely utilized.

The conclusion of the same article contains the following new condition relative to municipal concessions:

Munieipalities mal reconvey to third parties the exploitation of waters rested in them for the benefit of public service. snch as electric lighting, railway traction, and for domestic or hrgienic muroses. provided they follow a simple system of reimbursement of expenses of exploitation orel and above the interest ant anortization of eapital used. to the total exelusion of all speculation.

With reference to the duration and the renewal of concessions, it may be observed that perpetial concessions no longer exist. Article 5, the last paragraph only of which is new, is as follows:

Article 5. Concessions alle alnuted fol a period not exceeding thirty years; but at the expiration of that perion the concessionnaire las the right to a renewal of the concession for a second leviod of thirty years, with snch moditications as must he made in the conditions of the concession by reason of changes in the prenises or regimen of the stream. The renewal of the concession can be refused. if, in the opinion of the atministration, the concessionnaire during the preceding thinty roirs, either through usage or abuse, has not fulfilled the object of the concession. Renewals after the expiration of the second thirtyrear period are ontional with the nation.

There is an additional article, No. $5 \frac{1}{2}$, which contains an entirely new requirement, providing for the alteration of a power development found defective. This article reads as follows:

In order to better utilize watercourses on which concessions have been granted, such concessions may be suspended for certain periods and renewed in favor of new concessionnaires, under condition that the first concessionnaire receive, without cost or risk, a quantity of power or water equivalent to that of his concession, the rentals and other obligations stipulated by the decrees of investiture remaining the smme for all concessiomaires. 
Finally, article 4 of the proposed law contains a provision, almost identical with a paragraph of article 14 of the regulation of 1893 , which is very important in the gradual development of large concessions. It is as follows:

Whenever it shall occur that any concessionnaire cin not employ immediately all of the water or all of the power conceded to him, the conceding anthority can consent to a progressive development, subject to the miform payment of an equitable rent. The different periods of progressive utilizition shall be fixed in the decree of concession, as well as the quantity of water ol power that may be utilized in each period and the corresponding rental. Decrees which do not contain such limitations are rendered roid and must be renewed.

Decrees of concession shall define, in conformity with the regulations adopted, the periods within which the concessionnare must fultill the varions conditions of his concession, whether fixed or gradnil, up to the complete utilization of the witer to be diverted. If these periods are exceeded without sufficient cause, the administration has the privilege of declaring the concession forfeited or of restricting the quantity of water or power actually utilized.

These periods can not be extended, except for the enlargenent of capacity of the development, without a renewal of the application and the issue of new instructions.

5. Changes in assessment of rentals. The proposed new law preserves the rental of 3 francs (about 55 cents) per horsepower, fixed by law of 1884 ; but it introduces, in connection with long-distance transmission, a principle of reduction, which is in harmony with the views expressed by the congress of electricians at Turin and which will, without doubt, be somewhat unacceptable to the populations of the valleys in which the powers are located because it will favor longdistance transmission of power, to the detriment of local interests. The basis of the reduction is as follows:

For power transmitted by menns of electricity to distances greater than 10 kilometers (abont 6 miles) there is granted upon the anmul rental of 3 francs per horsepower, a reduction calculated ly multiplying the square of the distance expressed in kỉometers by a fixed coefficient of 0.001 . In no case shall the rental be reduced to less than one-half of 1 flanc per horsepower.

Under this formula the minimum reduction, that is to 0.50 franc, will be attained in transmission orer 50 kilometers (about 31 miles).

6. Power of expropriation. Examination of the law of 1884 and its various provisions has enabled us to review the fundamental principles of Italian legislation as well as to compare it with French legislation. In order to complete this exposition and to set forth all the elements involved in an intelligent comparison, some supplementary remarks will be required.

Although in Italy the more formal concession takes the place of the French permit and water regulations, the numerous formalities thereof, which are fixed with such detail by the regulation of 1893, apparently do not entail longer delays after the filing of the application than does the French procedure. On the contrary, the Italian 
regulation of 1893 permits an official examination more rapid, more compliant, and at the same time infinitely more complete, and it not only covers considerations of drainage and irrigation, but also advantages and disadrantages of the enterprise. An application is not accepted and examined unless it is aceompanied by plans and specifieations by which classification (provided by a supplement to the regulations for large diversions or diversions of the first class, article 3 of the regulations) may be simplified. The applications, together with accompanying explanatory documents, are, a fter examination by the provincial deputies, subjected to individual examination for fifteen days by a prefectoral commission which shall fix within the same period the time for risiting the porrer site. These formalities accomplished, the administration can act on the report of the civil engineers.

If there intervenes no consideration of the higher interests of the nation, the decision can be rapid; but, in accordance with the circular of Gen. Ifan de Rivera, all applications must be first examined in their relations to the present or future needs of the services of the nation.

We have indicated above, in the citation of article 3 of the proposed law, that in accordance with that article the preliminary examination must be rested in a mixed permanent commission, without reference to the advice of the rarious ministers. This is a procedure burdened with complications and delays, which has occasioned many complaints and provoked much uncertainty.

One real adrantage of the Italian legislation is that, while it protects specifically the interests of third parties by granting them all opportunity to be heard and by proriding for all needful examinations, it grants to the concessionnaires the right of arailing themselves of the law of June 25. 1865. concerning expropriation, and even stipulates that the individual inquiry shall serve equally for the declaration of public utility of the enterprise (last paragraphs of article 1 of the regulation of November 26, 1893). In conclusion, it is remarkable that the number of cases in which it has been necessary to have recourse to expropriation has been very small.

\section{SWISS LEGISLATION.}

Each of the twenty-fire Cantons of Switzerland has its special legislation or simple jurisdiction orer the waters within its boundaries, and the cantonal authorities, without interference from the Federal Gorernment, regulate the use of water powers in their own way and in aceordance with divers principles. To examine and compare them all would be an extremely laborions task. Fortunately, at a recent period and in comnection with circumstances that we will explain, 
this work of inquiry, compilation, and comparison has already been undertaken and well carried out under the eare of the federal administration.

\section{INQUIRY INTO EXPEDIENCY OF WATER-POWER REFORMS.}

In April, 1891, the Swiss society "Frei Land" issued a petition demanding the insertion of the following elanse in the Federal Constitution :

All the water powers of Switzerland not yet utilized are the property of the Confederation. A federal law shall regulate all that concerns the application of this resouree and the distribution of the net benefit forodnced by it.

In order to procure information concerning the value of so radical a proposition, the Swiss Federal Couneil, by circular of September 8, 1891, began an inquiry in all the Cantons concerning the extent and importance of the water powers, the existing laws and procedure with reference thereto, and the expediency of the reform proposed by the Frei Land Society. It consulted at the same time varions technical and industrial anthorities, and finally directed $\mathrm{A}$. Jegher, an engineer of Zurich, to study all the data assembled as a result of such inquiry and to formulate therefrom practical deductions.

The conchusions at which the Federal Council arrived and which it embodied in a report of June 4, 1894, approved by the Federal $\Lambda$ ssembly April 4, 1895, are as follows:

1. 'The great majority of Cantons which possess and exereise the right of sovereignty over their watercourses and which often derive direct income therefrom are not disinosed to renounee that light of sovereiguty.

2. In general, the public interest in this matter is safeguarded by the Cantons according to the importance in each ease.

3. The transfer to the Confederation of the right of sovereignty and of administration over water rights would not afford any adrantage to the comntry and wonld not present any sonrce of new revenue, either to the Confederation or to the Cantons.

4. The possibility of arailing itself of the water powers in the future could very easily be reserved to the nation by cantona l legislation.

5. In general. the cantonal authorities ale better able than the Federal Gorermment to see to the highest development and ntilization of water powers, both from an economic point of view and from that of public and industrial interests.

6. The importance, sometimes limiter. of the object in question and the securing of a rational use of the various falls, which is often difficult, require the cooperation of the cantonal authorities specially qualified to protect the develop. ment of the local trades and industries of the Cantons.

The Federal Comeil and the Federal Assembly, by coneurrence in their conclusions, were of the opinion that for the above reasons the petition of the Frei Land Society should not be approved. 


\section{REFORMS RECOMMENDED BY FEDERAL AUTHORITIES.}

After the conclusion of the important inquiry, upon the motion of the Swiss Frei Land Society the Federal authorities, while deciding to maintain the prerogatives of the Cantons, nevertheless recognized and set forth the need of establishing a certain unity in the laws of the Cantons. The need was expressed for a certain coordination in the matter of regulations still existing in favor of navigation, together with those defining the right of expropriation and prescribing the procedure to be followed. It was recognized that there should be miformity in the regulations governing the diversion of waters.

It was deeided to recommend to the Cantons that they incorporate into their laws regulating the control of waters the following principles:

1. The cancellation of prescriptions relative to navigation, in so far as they interfere with the development of water-power plants, unless said prescriptions are justified by the actual demands of transportation.

2. The adoption of the jrinciple that all progress in the utilization of water power shall be considered as of public utility and that in consequence all installations for power purposes can demand the application in their favor of the laws relating to expropriation.

3. The formation of companies for the economic improvement of watercourses utilized by many manufacturers, with compulsory participation of all interests.

4. The right of the cantonal authorities to investigate the industrial value of proposed enterprises and to hase their decisions relative to application for power sites on the results thereof; also, their right to reserve to their own use or that of an interested community any power site; in case of such reservation, the period which it shall covel and the form of notice that shan be given by the Cinton or community of whicl it is in favor.

5. 'The reservation that, in case of damages sustained by the owners of waterpower plants by reasom of inprorements made in watercourses in the public interest, salid owners shall not be entitled to indemnity.

6. 'The limitation of the term of the concession to a fixed number of years. with clauses of forfeiture in cases of nonutilization, or of redemption by the Canton.

7. 'The establishment of a cantonal register of the water regulations, following uniform standards fol the entire Confederation.

With reference to intereantonal relations, the council of state was of the opinion that the Confederation should have the right of intervening in all cases where the operation of a water power involved two or more Cantons, upon application from one of the Cantons or from the applicant for concession. Intercantonal relations must be regulated by federal law. Federal law or regulations must also apply to questions of public security as affected by the constructions and electrie conduits of high tension.

Finally, the report of June 4, 1894, is concluded with a proposal relative to the establishment of a complete and exact statistical record of water powers. 
It will be seen that in Switzerland respect for the prerogatives of the Cantons and communes has not hindered the nation from endeavoring to exercise its beneficial influence in all legitimate ways.

\section{DIFFICULTIES INVOLVED IN ELECTRIC TRACTION OF RAILROADS.}

The federal authorities have acted only by giving advice. Will they never feel the necessity for more effective intervention? A very serious difficulty will, without doubt, spring up. The Swiss Confederation has redeemed all the railroads in general public use, and will take over the direct operation thereof within two years. How will Switzerland solve the problem that has so passionately agitated Italy, and reserve to itself the water powers necessary to the electric traction of its large railroads? There is nothing to indicate the manner in which the problem is to be approached and solved. whether by friendly agreement between the Confederation and the Cantons or by the passage of federal laws. It is clear that, before committing itself, the Federal Government is endeavoring to procure all necessary information. The important statistical work of the Swiss hydrometric service will probably have as its principal purpose the furnishing of precise data on this subject. The Federal Assembly, at its session of December, 1898, took the first step. It invited the Federal Comncil to present a report on the question of whether the nation should not secure for itself the powers furnished by watercourses of constant flow, favorably situated for use in the development of the railroads of the nation.

In what way has each of the Swiss Cantons, since the inquiry of 1891, modified its standards and laws, either to accommodate them to the new demands of hydro-clectric industries or in consideration of the advice of federal anthorities? We are not yet completely informed in the matter, onr investigations so far having eovered only a small number of Cantons. It appear's that there is a very marked tendency to imitate the example of Geneva, which is very encouraging. Everywhere the Cantons and communes are studying the matter of developing and exploiting to their advantage the vast enterprises of power distribution. We will cite the Canton of Vaud, which is trying to bring to Lansanne power from the upper Rhone; that of Fribourg, which has decided to create a distribution system to be served by the powers of Montbovon and Hanterive; that of Zurich, which, after having settled, through the federal tribmal, its difficulty with Schaffhausen relative to the ntilization of the Rhine, proposed to establish on that river four plants of 25,000 horsepower, from which it will distribute power within all the centers of commerce and industry, 
In this connection it may be said that, by reason of their administrative precedents, the Swiss people have been accustomed for a long time to the idea of their Cantons and communes embarking in industrial enterprises, as is indicated by the form adopted for their encouragement of public-utility enterprises. The Canton of Berne, for example, has aided its railroads by taking their stock, and the grand council announced to the people of Berne in a message of January 28, 1897, that the nation had recovered, without any loss, the fifty millions that it had invested in the construction of the first railroad system, and that it proposed to cooperate in like manner in the establishment of the second system by taking stock to the extent of 40 per cent and for some lines even 60 per cent of the capital required in first construction. From the results first obtained, it is hoped that the hydro-electric enterprises for distribution of power may prove even more advantageous to cantonal and municipal financial investments than have the railroad enterprises.

\section{WATER-POWER CONCESSIONS IN CANTON OF BERNE.}

In the Canton of Berne a large number of concessions for waterpower developments have been granted to groups of communities, as for example, the company at Hagneck, composed of the towns of Nidan, Tauffelen-Geriafingen, Hagneck, Bienne, Cerlier, and Neuveville; and that at Wangen, composed of the towns of Wangen, Wiedlisbach, Walliswil-Wangen, Walliswil-Bipp, Berken, Bannwil, and Graben. Many more might be cited. But, in the absence of municipal activity, private initiative has also taken part in the development of water powers. The following quotation indicates the attitude of the executive council in the matter:

We consider that it is the communes on which the law imposes the obligation of establishment and maintaining dikes and dams, and who for years and for centuries have had to bear the expense of maintaining the banks and protection works, withont taking into consideration the great rlamage to which they are often subject on acconnt of inundations, who should profit by the wealth that lies in the ntilization of water powers. They have the first right to obtain concessions, and the undersigned [M. Dinkelmann, director of public works, October, 1891] misses no opportunity to call the attention of the representatives of the community authorities to this fact. All demands for concessions must be published and the specifications filed in the proper communes. The authorities of the commune can oppose them and can intervene as applicant and thus secure by cheap water power the means of sustaining and improving their industries. It is thus our purpose to have the country itself profit by the water powers loeated.

If, for any reason, the commume can not or does not wish to take the matter into its own hands, it seems to us that it will be the duty of the nation to see that the country is not completely deprived of its water powers and to arrange that the commune can hare, at net cost, the use of at least enongh water power for public-utility works, electric lighting, distribution of water, etc. We recommend the regular insertion of such a condition in concessions of this class. 
This definition of position is an extract from a voluminous report, ratified by the executive council and by the grand council of the Canton of Berne, having for its object the examination of concessions for water powers, following the federal inquiry brought about by the petition of the Frei Land Society.

The report demonstrates first and foremost that the right conferred by the law of Berne "in the matter of the utilization of watercourses presents many deficiencies and is very defective," and that until a new law is promulgated it will be necessary to seek improvement in the limits of existing legislation. Finally, it proposes a formula for concessions which seems to have the proper precautions and clearness. This formula will be followed until the situation is a little clearer and until there shall be formulated, with the cooperation of jurists and technical experts, a comprehensive law.

The formula in question provides certain rules in the matter of filing of application, examination and approval of projects, assignments, and modifications, concerning which no comment need be made. It also includes, however, two articles which it will be well to cite in full:

ART. 13. If future laws shall confer upon the nation a monopoly of the utilization of water powers or of their transmission by electricity, compressed air, etc., or if the nation or the communes shall find need, in connection with their public services, for water powers that have been conceded, any existing authorization may be withdrawn without indemnity in case the articles of concession do not formally guarantee indemnity; likewise, except in such case as above mentioned, the concessionnaire has no right to indemnity when changes made in watercourses in the public interest no longer permit him to use the water for his power plant.

ART. 14. If future laws shall limit the term of concessions of this class or shall exact specific rentals for the utilization of water powers, such new requirements shall also be declared applicable to concessions now existing.

With these two clauses inserted in all articles of concession, the cantonal authorities of Berne may look forward with tranquility to a revision of existing laws. Upon reflection, it will be seen that these clauses are not so drastic as they would at first appear. The laws that shall be promulgated, even the taxes that shall be imposed (the report of M. Dinkelmann refers to taxes), could not be too severe in effect so long as they permit the development of powers not theretofore utilized. In retrospectively applying these laws and taxes to enterprises already developed, one may be certain that such enterprises will not be crushed, for, in the first place, they will have passed through the first years of development, and, in the second place, the waterfalls first developed are naturally the most economical. Concessionnaires who accept such regulations in advance of their promulgation are not, in reality, imprudent. They will even have certain advantages over their future competitors, because generally 
they will be in better position to bear the obligations imposed by the communes.

The formula drawn up and approved in 1891 has been applied in the Canton of Berne to numerous commune or private concessions. We will cite especially the concession of power on the Kander at Spiez (Thun Lake). That concession is of 2,500 horsepower; the head is 64 meters (210 feet); the flow about 4 cubic meters (142 cubic feet); the pipes can carry a maximum flow of 8 cubic meters (284 cubic feet). The power will be developed by the Motor Company of Baden and will be used especially on the railroad now under construction from 'Thun to Bugdorf. The concession act, approved May 6, 1894, includes articles 13 and 14 quoted and discussed above. It contains in addition clauses of forfeiture in case of nonexecution of the projects or of nonutilization of the water, and a reservation in faror of the towns of Wimmis and Spiez of a right to the use of 200 horsepower and 300 horsepower, respectively, at the turbine shaft, at charges equivalent to net cost. This right fails if advantage is not taken of it within a period of five years.

\section{FLEXIBILITY OF CANTONAL LAWS.}

We can not review with the same detail all modifications in regulations arlopted by the other Cantons following the inquiry of 1891, although it would be a very interesting study on account of the great variety in the procedures adopted. The most striking point is the eagerness of the cantonal anthorities, as soon as the necessity was made apparent to them and without waiting for the laborions revision of general laws. to adopt special laws or simply regulative measures for safeguarding in an effective way the public interests involved. Objections in principle or even obstacles presented by antiquated laws do not earry much weight in the face of the accomplishment of a practical purpose.

The flexibility of Swiss law is truly astounding. A few months sometimes suffices to procure a special law necessary to a large enterprise of an exceptional type. A system which permits such rapid organization merits admiration. We will cite the Water Power Company of Arancon. in the Canton of Vaud, which was created, organized, and directed by Professor Palaz, of Lausanne, an eminent specialist on the subject. In March, 1897, Mr. Palaz called a meeting of capitalists for the purpose of explaining to them the object of the enterprise. It involved the development of 1,300 to 3,000 horsepower orer a 544-foot fall, to be used principally for electric traction on a system of railroads between Bex. Gryon. and Villars, a system built and operated by the company itself, and secondarily for the 
distribution of power to Bex and vicinity. In April, 1897, he had secured the necessary capital, $\$ 2,362,000$ (1,270,000,000 francs.) The work was commenced in May, 1897; the distribution of power began in January, 1898; the first section of railroad was opened a few months later. Moreover, it should be noted that expropriations were involved. How enviable are administrative procedures that, in the face of incomplete and contradictory general legislation, permit such results.

\section{VARIATION IN LEGISLATIVE TENDENCIES OF THE CANTONS.}

A general comparison of the Swiss Cantons with reference to legislation in the matter of water power wonk be very interesting. Some of them wish to nationalize or municipalize their water powers, while others wish to reserve them to private initiative. It would be very instructive, when the essential elements of such a comparison are a vailable, to ascertain the real canses for the opposing tendencies, which depend, without doubt, on economic conditions and not on artificial or superficial currents of opinion. It would very probably be found that among the partisans of nationalization were the richest Cantons, the most populous ones, the greatest industrial centers, those where the most important field for ntilization of water power lies in already existing enterprises. 'The development of power under such conditions presents little industrial risk. On the contrary, the poor Cantons, where industry is little developed and where water powers do not find such ready application, without doubt recognize the necessity for encouraging private initiative, which alone can create and encourage the locating of the necessary industries under the incentive of great promise of benefits. In this category belong most of the Departments and communes of the French Alps, which can not even hope to follow the example of the rich Swiss Cantons in the direct development of their water powers. But this is not sufficient reason to prevent their assuming an important part in the work of controlling their watercourses by means of retrocessions to industries.

\section{SUPPLEMENTARY NOTE.}

By M. O. LAigITTON.

Since the foregoing statements were written by M. Tavernier, his predictions relative to the necessity for federal intervention in Switzerland have been justified. The congress has completely reversed the action taken in 1894 in response to the petition of the Frei Land Society, and this reversal was approved by an overwhelming vote of the people. The following amendment was adopted on 
October 25,1908 , by a popular vote of 292,997 , against 52,180 in opposition :

Article 24b. The Federal Congress shall have supervision over the development of water powers.

The Federal Congress shall make provision for the disposition of water-right concessions, shall prescribe the terms thereof. and shall regulate the transmission and distribution of electrical energy so far as may be necessary to protect public interests and to provide for the proper development of such resonrces.

All water rights to which the terms of the ferleral law do not extend shall be under the jurisdiction of the Cuntons, which shall dispose of the concessions, regulate the same, and impose taxes and fees for their use, but such regulations, taxes, and fees shall not he so serere as to merent or inhibit the derelopment of water powers.

'The National Govermment shall regulate and dispose of concessions for powers located on intercantonal and national boundary streams, and shall determine the taxes and fees to he imposed thereon. aftor liearings have been granted to the Cantons interested, but such taxes ani fees shall be collected by the Cantons.

No power developed on a stream located within the Union shall be transmitted to a foreign comntry without the consent of the Federal Comeil.

The provisions of the federal law shall apply to water-right concessions already existing, except in cases specifically exempted therefrom by law.

\section{PROPOSED LAW FOR THE REgULATION OF PUBLIC WATER-POWER PLAN'TS. $a$}

\section{GENERAL DISCUSSION.}

In order to understand the difficulties presented in the utilization of water power [in France] under existing law, it is necessary to distinguish between navigable and nomnavigable watercomses.

On navigable watercourses that are a part of the public domain the owners of the banks have no rights whatever. The nation can grant permits where it believes wise, without respect to any right of nsage. The legislation therefore places no obstacle in the way of development of large water powers on these streams, for the general good. The principal difficulty is that these permits, like all others granted over the public domain, are precarious and can be revoked without indemnity. Consequently it is difficult to induce capitalists to engage in so costly an enterprise.

On nonnavigable watercourses the situation is entirely different. The water is not domain; it is res nullius, and the riparian owners, who are also owners of the stream bed, have a right of usage in the water. 'They are permitted to utilize the fall provided they do not infringe upon the rights of other riparian owners, and are restricted only by the administrative permit which covers police control. The

a Presented in the name of XI. Emile Loubet, Plesident of the French Republic, by M. l'ierre Baudin. minister of public works, and M. Jean lupuy, minister of agriculture, to the commission on distribution of power. (Extract from Bulletin of the Soclety for legislative studies, on the utilization of water powers.) 
riparian owner can dispose of his water right, in which the nonriparian owner has no interest. Nevertheless, the rights of the riparian owner apply to the limits of his own property only, for he has to respect the rights of his neighbors across and up stream. If in any development he has used the falls in the stream above the border of his own holdings, and the upstream owners subsequently wish to make use of their rights, they may obtain from the courts a ruling that will deprive him of a part of the power that he has been using. Therefore it is necessary for those who wish to develop large power plants to enter into an agreement with all the other riparian owners who possess coneurrent rights. Even the validity of such agreements is contested, it being conceded only with reluctance that rights in the water can be disposed of without reference to rights in the land.

This condition explains the appearance of water-power site speculators, called "pisteurs" or "barreurs de chutes," who by purehasing a narrow strip of shore line aequire riparian rights sufficient to prevent the establishment of power plants, in order to aid them in an effort to sell such rights at an extortionate price. 'The water powers of such streams are therefore either in the hands of speculators or of small owners who ean not possibly utilize them in the manner required by the great industries. To the great detriment of public interests, the powers are thereby rendered unavailable.

There is, however, one case in which it is possible under present legislation to utilize the powers of nonnavigable streans despite all riparian rights - that is, in the case of public works declared of public utility in the interest of the public service. If. for example, a water supply for a town is to be established, or eleetric power for lighting a city or for use of a street railway is to be installed, a decree will be issued decharing those works of public utility and conferring on the concessionnaire the right to the necessary power, under the limitations and conditions of the decree, independently of all rights emanating from the civil code.

The effect of such a decree is to combine the rights of the individual users into a common right to indemnity for any damages caused by the execution of public works, there existing, however, no right to indemnity except in case of damage actually sustained. A riparian owner who has previously made no use of his riparian rights can not set up a claim for indemnity. Moreover, there is vested in the concessionnaire, as a result of the declaration of public ntility, the right of securing, through the process of expropriation. the lands necessary to the execution of the works. This procedure thus permits the utilization of a part of the watercourse in a satisfactory manner whenever the public service is properly concerned, which alone can be the purpose of a declaration of public utility. This principle can 
not be applied in the interest of one or of many great industries, nor in the interest of public service and industry combined.

To remedy the defects of the present legislation, two means come naturally to mind, both involving the right of concession of the waterpower sites of watercourses. The first means is that adopted by the Parliamentary commission charged with the examination of the law proposed by M. Jouart, reported by M. Guillain. It consists of creating a new right by declaring the power plants as of public utility in all cases where the interest of public service can be claimed, under conditions actually demonstrated in evidence. It involves practically a concession of ownership in water power destined for private industries, under the obligation to reserve water or power for eventual public service. This would be, in effect, a right of perpetual proprietorship in the water power and the works necessary to the establishment and operation thereof, constituting a "conceded power plant," rather than a "power plant of public utility." Such a concession would be very similar to concessions for mines. To follow the same line of thought, this new private right might be made not a right of perpetual proprietorship but a right of temporary usage, which after a certain period would revert to the nation.

The second means consists of adopting as a basis for the reform the concession in regard to public service just as it exists to-day; that is, the concession for public works. It would be sufficient to extend this to all cases by applying it to private privileges now existing or to be created in the future. This is the system adopted in the proposed law; it is justified by the following considerations:

1. It is preferable not to attack any of the general rules of the civil code or the special prineiples of legislation regarding waters. The establishment of a new water right might involve serious difficulties, theoretical as well as practieal. It will be better to adhere to a legal principle already established, defined, and practiced, viz, the concession for public works with amendments necessary to cover the abovementioned needs.

2. It will be futile to have two different types of concession, one for industrial purposes and the other for public works. Standards for such will be difficult to establish, for in all cases there will be a possible or prospective public interest as well as a private interest to be served at the same time. For the highest utilization of the power this must always be so. Sometimes the public power plant must tum over its surplus to the private industry; sometimes the industrial plant must help out the public service. On the other hand, the admission that a proposed enterprise is of sufficient general utility to merit the use of the declaration of public utility, regardless of the rights of others, places an immediate obligation on the nation to reserve into itself the right to impose on the concessionnaire the obligation to develop a large water power, destined ultimately for 
public service, whenever needed. Is it therefore not right to hold that the power plant created under such conditions has the character of a public power plant, permitting the application to it of the system of concessions for public works?

3. This conception has the advantage of taking into consideration the duration of the concession, for it must of necessity, like all other concessions for public works, be limited. I perpetual concession of ownership would present grave difficulties in a case where the development was still in the trial stage, where it would be hazardous to make definite plans for the future, and where the value of the water power might, under certain economic conditions, be increased in proportions impossible to foresee.

4. This plan permits the application of principles that have already the sanction of administrative practice and of the law.

The proposed law, whose general principles will now be set forth, has been prepared in pursuance of these ideas, adrantage having been taken of all the provisions of the project of the parliamentary commission that can be adapted to the system of concession.

\section{DISTINCTION BETWEEN PRIVATE AND PUBLIC PLANTS.}

Private power plants are those which will continne to be established under the system of the granting of a simple permit in accordance with the civil code and with present water laws and regulations.

Public power plants are those which are established moler the authority of the new law; that is, by means of concession in virtue of an act declaring them of public utility. Such a declaration shall be made by a decree rendered in accordance with the decision of the state comcil, save in exceptional cases, for which a special law is necessary.

Power plants on ordinary streams, with a gross capacity of 100 horsepower or more, must always be established as public plants. In such cases there is always a possibility of the exploitation of a large power, which overweighs the ordinary considerations in connection with a private plant under present conditions and which justifies the intervention of the Govermment, so that there may be assured a reservation of power sufficient for the future needs of public service. It is intended that this shall not affect private power's which exist at the time of the creation of the law, except those plants whose capacity the owners propose to increase.

\section{UNIFORMITY IN REGULATIONS FOR NAVIGABLE AND NON- NAVIGABLE STREAIMS.}

Legislation with reference to public power plants shall apply to navigable as well as to nonnarigable watercourses. The result of such a provision will be to aroid the uncertainty that has existed with reference to public power plants on navigable watercourses. This 
provision is absolutely necessary to encourage the establishment of large industries, which can not with financial safety risk possible arbitrary action of the administration, which is free at any time, under present conditions, to revoke the permit without indemnity or to undertake in the interests of navigation works that might bring disaster to the investment. No inconvenience will result from putting an end to the arbitrary control, which is much more damaging to the highest development of natural resources than it is profitable to the interests of the public works. Public water-power plants should have the same guaranties over all watercourses as those established under title prior to the year 1556 or before the national sales under the Revolution. It has been recognized in various instances that the public domain does not prevent the nation from conferring on concessionnaires, by means of the declaration of public utility, certain rights the withdrawal or diminution of which gives rise to indemnity. This principle applies to concessions for street railways over public roads. What it is possible to do on public-land domain it is possible to do on public-water domain.

\section{CHARACTER OF CONCESSION.}

1. The concession is granted by the nation in the interest of industry and of the public service. It can be granted either in anticipation of an immediate public service, with the privilege of recovery either at that time or in the near future; or for the use of one or more private establishments, with reservation of quantities of water and power sufficient to supply the public service ultimately to be created.

2. The concession covers water power and works, lands, and structures appurtenant to the operation thereof, as well as canals designed for purposes of drainage or irrigation, which may be imposed upon the concessions, but does not extend to the plants or equipment which are erected for the industrial utilization of the power created and which are located at a distance from the site. The separation is complete between the public water-power plant and the transmission system for private or public utilization.

3. The concessionnaire may dispose, as he sees fit, of water or of power not immediately appropriated to or reserved for future public service. On the other hand, he is bound to furnish to present or future public service water and power under conditions and at rates fixed by the conditions of the concession. In order to avoid loss of benefit from water and power not now utilized but merely reserved for future public service, the law provides that it may be temporarily appropriated to private industries by specific contract. The conditions of the concession prescribe the circumstances under which such contracts can be made and the period of notice which shall be 
given when it becomes necessary to furnish such power for the public service. It might, for example, be advisable to let contracts for a portion of the power for a long period and for other portions for shorter periods, according to the probable proportions of the future needs for the public service.

4. The construction work shall be subject to the approval of the minister only in case public safety or the regulations concerning control of waters are affected, or when the works to be constructed shall involve expropriation. In all other cases administrative anthorization is unnecessary.

5. The public power plant, with all its stationary appurtenances, is classed as public domain; its works are considered like those of the public highway, for purposes of protection against infractions of contract.

6. The administration shall have the right to prescribe measures necessary in the interest of public health and safety, as, for instance, the prevention of inundations, and the concessionnaire shall have no right of indemnity. In all other cases, on the contrary, if the measures prescribed or works constructed (as, for example, works constructed in the interest of navigation on navigable streams) result in any difficulty whatsoever in the operation of the plant the concessionnaire shall have a right to indemnity.

\section{METHOD OF GRANTING CONCESSIONS.}

The concession shall be granted after the filing of an application setting forth the advantages which the applicants believe will accrue to the public interest, and after examination by a "mixed commission on water-power plants," created for that pupose. It imposes upon the concessionnaire obligations of two kinds-first, the duty of furnishing a certain quantity of water or power for the public services, either free of charge or at an equitable rate; second, financial cooperation, when it shall be necessary, in other public-utility enterprises of the section.

A question may arise as to whether it would be good policy to exact payment of a rental. There is no doubt that the imposition of such a charge would be justifiable. The principle has been approved in connection with present legislation concerning plants on navigable streams. It is desirable, however, to avoid giving to the proposed law an appearance of being a measure for revenue. It is better to obtain from the applicants the equivalent of rental by making provisions that will be in the interest of the public service. This may be accomplished either through a reduction in the rates for furnishing power (it sometimes being possible even to obtain this gratuitously) or through an agreement on the part of the concessionnaire to 
perform certain services in part or in entirety, such as the construction of important public works, the benefit from which will accrue to the region in which the concession is located. Such services may include the construction of a roadway, a railroad, a street railway, the laying of conduits for lighting, distribution of power for smaller industries, etc. This would be an extension of a principle recently introduced into concessions for mines, which makes for more profitable cooperation between the industrial interests and those of the general public, a point which should not be overlooked.

\section{RELATIONS WITH THIRD PARTIES - DAMAGES - EASEMENTS-} EXPROPRIATIONS.

1. Usages.-The works are public works, and damages resulting therefrom may give rise to indemnity, under ordinary conditions, in accordance with regulations now in force under the law of December 29,1892 , and with the distinctions recognized under the decision of the council of state. The declaration of public utility renders void the rights of usage which constitute an obstacle to the right conferred upon the concessionnaire, and converts them into a right for indemnity for damages caused by the execution of the works. Only those who sustain actual damage can claim indemnity, such as those who are deprived of water or of power of which they have made beneficial use. The concessionnaire can always free himself of this obligation of indemnity by restoring, in kind, to the user's the water or power so confiscated. This is a method of settling damages which often has the double adrantage of being more economical for the concessionnaires and of aroiding the wiping out of power plants or irrigation systems previously existing.

2. Landowners.-Damages to landowners may result either from the occupation of their lands in connection with the establishment of works, or from flowage of lands occasioned by dam construction. The proposed law distinguishes between a damage which would put the landowner to little trouble and would entitle him merely to indemnity for granting a right of way and a damage involving expropriation. Rights of way would be granted for the establishment of canals, underground conduits, and power transmission. The eonditions controlling the granting thereof are determined by civil tribunals, charged with the duty of reconciling the interests of the enterprise with other proprietary interests. The question was considered of defining in the law the various conditions under which rights of way could be procured, but it appeared that it would be difficult to establish sufficiently clear and fine distinctions to cover all contingencies, and consequertly it was believed preferable to leave the matter to the control of the civil tribunals. The occupation of the river bed and 
the submergence of shore lands not susceptible of cultivation can be accomplished by paying for the right of way, without the necessity of resorting to the expropriation procedure.

In all other cases-that is, in all cases where occupation by acquiring a right of way is not practicable-the concessiommaire must acquire title to the necessary lands upon which his works will be built or which will be submerged by the raising of the water level. The method of procedure in expropriation is governed by article 16 of the law of May 21, 1836.

\section{TERMINATION OF CONCESSION.}

A concession shall be terminated, first, by regular expiration of the term thereof; second, by redemption; third, by forfeiture. The common rules in the matter of concessions for public works must necessarily be applied here. It has, however, seemed advantageous to formulate certain special provisions in order to assure a continuation of the service after the termination of the concession and to avoid the uncertainty and interruptions in the enterprise to which changes in ownership might give rise. When a concession is terminated, the new concessionnaire (and in the case of redemption, the nation) is bound to guarantee for a period of five years the fulfillment of contracts held by the old concessiommaire for the furnishing of water and power, subject to the limitations imposed by the controlling conditions of market at that time, and to assure the granting of preference to such public-service demands as may exist.

It is also important, in case of the regular expiration of the period of concession, to provide that the new concession shall be granted some time in advance of such expiration, so that there may be no period of uncertainty just previous thereto. It seems reasonable, as well, to give to the holding concessionnaire the preference in the matter of new application, if he offers terms as advantageous to the nation as those of any of the new applicants. I change in concessionnaire is not always desirable and has no value other than that of securing readjustment of terms in harmony with seientific progress and industrial development. If such advantageous conditions are secured it is usually better for all interests to have no change in the concessionnaire. To this end the proposed law imposes on the administration the duty of arranging the new concession within the five years preceding the expiration of the old one. The method of procedure is identical with that followed in the first concession, except that the right of preference is accorded to the holding concessionnaire. In order to avoid delays which will prolong the examination up to the final days of the period of the first concession and to avoid falling into the uncertainty that would result therefrom, it is 
decreed that, if two years previous to the expiration no new concession is being instituted, the concessionnaire can demand an extension of his concession for a period of ten years. This ten-year period of extension seems necessary, and at the same time sufficient for the amortization of the expenses of repair and improvement that the concessionnaire would feel called upon to make when entering on a new period of operation, and to encourage him in so doing.

These provisions as a whole seem to overcome the greater part of the objections made by partisans of the system of perpetual ownership to the system of temporary concession. Such objections are generally based on the difficulty of assuring a good development during the period of change.

With reference to redemption, the proposed law provides that indemnity shall be fixed by arbitration, under the principles laid down by article 11 of the law of June 11, 1880, concerning railroads of local interest. In order to simplify the procedure, in case of forfeiture or redemption, it is proposed to give cognizance to the state council direct, without requiring review by the council of the prefecture; this provision is in accordance with the law of Jume 11, 1880, above cited.

The proposed law, which contains four sections and eighteen articles, is submitted below.

\section{THE PROPOSED LAW.}

SECTION 1 .

Article 1. Hydraulic powers, from whatever waters they may be derived, shall be classified as private powers and public powers. Private powers shall continue to be governed by the laws and regulations now in force. Public powers shall be regulated by the following provisions:

Articue 2. Public powers are hereby conceded to the nation in the interest of industry and public service. When the only use immediately foreseen is the serving of one or more industrial establishments, the reservations necessary in the interest of eventual public service shall be embodied in the conditions of the articles of concession.

Article 3. Public powers are declared of public utility and conceded by decree of the state council, based on the report of the minister of agriculture in the case of nonnavigable waters or of the minister of public works in the case of navigable waters, and after inquiry and adrice of the general council of the Departments, of the municipal councils of the towns interested, and of the commission created under article 16 hereof. No declaration of public utility shall be made in the absence of legislation authorizing the same, in the case of proposed works involving the diversion of water from 
its natural channel for a distance greater than 12 miles (20 kilometers) measured along the river bed. Such legislation shall, previous to passage, have bcen submitted to the state council. The modifications ultimately applying to the use and distribution of the water power and diverted water are authorized by decree of the state council.

Article 4. The conditions of the articles of concession shall fix-

1. The period of concession.

2. The works, grounds, buildings, and equipment of all kinds that constitute the stationary appurtenances of the concession. Such appurtenances comprise installations for the improvenent of the regimen of the stream, the diversion and retention of water, the conversion of hydraulic power into mechanical or electric energy, the transmission of water and power, and finally the maintenance and operation of the various installations. They do not comprise works designed for the utilization of the power produced or water furnished, which might exist irrespective of the concession.

3. The amount of water diverted by the plant, and especially the minimum volume of water to be retained in the natural channel, or to be reserved in the interest of municipal water supply or of irrigation.

4. General conditions concerning the location of reservoirs and dams, the establishment of canals for diversion, discharge, waste, etc., and the character of the works which the concessionnaire is bound to establish without regard to the obligations to the public which he thereby incur's.

5. Charges imposed on the concessionnaire, whether in the form of water or power to be furnished to the nation, to the Departments, to towns, or to properly anthorized companies, or in the form of financial cooperation in public-ntility enterprises in the region.

Arricte 5. The declaration of public utility has the effect of classifying as a part of the public domain water-power plants and their stationary appurtenances defined in the articles of concession in conformity with paragraph 2 of article 4 hereof. Such works are considered as like those under the jurisdiction of the commission of public ways, especially in comnection with the suppression of violations. Such violations are liable to a penalty ranging from $\$ 3$ to about $\$ 55$ (16 to 300 franes).

Article 6. Plans for construction of works which affect public safety, or the control of waters, and the general provisions of those involving expropriation are subject to approval by the competent minister. Construction of other works is not subject to administrative regulation.

Article 7. The concessionnaire maintains the right to dispose freely of water and power not appropriated to or reserved for public 
service. Power so reserved and not demanded for immediate use may, pending such demand, be sold to private parties, under specific agreement, the terms of which shall be fixed in the articles of concession.

Article 8. Except in cases involving public health and safety, the concessionnaire of a public power, even when the power is situated on a navigable stream, has a right to indemnity for injury due to works constructed or measures prescribed by the administration.

\section{SECTION II.}

Rights and obligations of the concessionnaire with respect to the public.

Article 9. Works constructed by the concessionnaire in the establishment of a public power plant are public works. The declaration of public utility confers upon anyone deprived of water of which he has previously made use the right of indemnity. Reparation may consist entirely or in part of compensation in kind.

Article 10. In consideration of the payment of equitable and necessary preliminary indemnities, the concessionnaire may-

1. Establish and maintain, on or beneath private property, canals, tumels, and underground conduits necessary to the operation of the power plant or to the fulfillment of the obligations imposed by the decree of concession in the interest of irrigation or drainage, provided that snch works do not involve serions difficulty in the use of the surface of the ground by said private parties.

2. Conduct power-transmission systems over or under the ground, for which purpose he may erect the necessary supports and install accessory apparatus for the proper operation of such transmission systems.

3. Occupy the river bed and by raising the water level submerge the moncultivable shores of nonnavigable watercourses.

Existing buildings, yards, gardens, parks, and inclosures connected with residences can not be subjected to the rights of way established by this article.

In the matter of application for such rights of way, the courts must reconcile the interests of the enterprise with property interests. They may authorize a provisional execution of the works in consideration of a deposit by the concessionnaire of a sum fixed by them.

ArTICLE 11. In all cases other than those in which the rights of way defined in the preceding paragraph can be established, the concessionnaire is bound to acquire all lands necessary for the establishment of all works constituting the plant and its stationary appurtenances, as well as for proper construction and maintenance of dams. 
Indemnities shall be determined in accordance with paragraph 2 et seq. of the law of May 21, 1836.

\section{SECTION III.}

Articla 12. At the expiration of a fixed term the concession, together with all obligations as determined by the conditions of the articles of concession according to article 4 hereof, shall revert to the nation without indemnity. Within five years immediately preceding such expiration steps must be taken toward the institution of a new concession. The holding concessionnaire has the right of preference under equal conditions. If, two years before such expiration, no new concession has been instituted, he shall have the right to demand the extension of his concession for a new period of ten years. The nation or the new concessionnaire continues to be bound for a period of five years after the expiration of the original concession to fulfill the conditions of contracts for furnishing water or power held by the former concessionnile to the public services, and to individuals after the needs of the public service are satisfied. In no case can the nation be required to furnish larger amounts of water or power than those rendered possible by the conditions of utilization of the concession at the time of its reversion.

Articis 13. The nation may at any time after the expiration of the first fifteen year's repurchase the concession. Such redemption is decided by decree in the state council, in the presence of the concessionnaire, and must involve the entire concession. The nation is bound to fulfill the regular contracts for furnishing water and power entered into by the concessionnaire previous to the decision of the minister instigating the redemption proceedings, under conditions set forth in paragraphs 3 and 4 of article 12.

The indemnity for redemption shall be fixed by a commission created by decree and composed of nine members, of whom three shall be designated by the minister of public works, three by the concessionnaire, and three by selection of the six members already provided. If, within one month after the appointment of the representatives of the nation and of the concessionnaire, they shall fail to make unanimous selection of the threc remaining members, such appointments shall be made by the chief justice and associate justices of the court of appeals of Paris.

All disputes relative to the redemption are submitted to the council of state for settlement. Appraisal is obligatory, if demanded.

Article 14. $\Lambda$ concession shall be declared forfeited, under conditions as set forth in the articles of concession, by the minister, but the concessionnaire shall have the right to appeal to the council of state, which shall, in case such forfeiture is found to have been un- 
warranted, allow indemnity to the concessionnaire. The decision of the minister and the judgment of the council of state are announced to the concessionnaire and published in the commune in which the power plant is situated. The minister may, if he deems desirable, and shall, if requested so to do by the forfeiting concessionnaire or by owners of agricultural or industrial establishments holding valid contracts for the furnishing of water or power, institute proceedings for sale of the concession at public auction. Petition for such auction sale shall be made within three months after the publication of the decision of the minister or of the judgment of the council of state in case of appeal, and the petitioner must guarantee in advance the necessary costs of sale. The forfeiting concessionnaire can not become a purchaser. The proceeds of the sale belong to the concessionnaire. The purchaser is vested with all the rights and obligations of the forfeiting concessionnaire, with respect to both the public and the nation, under the conditions provided in paragraphs 3 and 4 of article 12.

SECTION IV.

\section{General ronditions.}

Articre 15. In case the concessionnaire shall fail to comply with conditions imposed in the articles of concession, or in ministerial decisions concerning details of construction, or shall disregard any water laws or regulations, or stipulations concerning duties to be fulfilled to the public service, the same shall constitute a violation of law and shall be subject to the same treatment as in matters relating to public ways, punishable by fine of 16 to 300 francs $(\$ 3$ to $\$ 55)$. In case of repetition of the offense within the same year, the maximum penalty shall be 3,000 francs (about $\$ 500$ ). Interference with the exercise of supervision shall constitute a misdemeanor, which shall be subject to fine by the proper corrective tribunal of 16 to 3,000 franes $(\$ 3$ to $\$ 500)$.

Antrcle: 16. There is hereby created, under the jurisdiction of the minister of public works, a mixed commission on water-power plants, charged with-

1. Examining and compiling data procured by cooperation between local services with reference to the control of waters, with a view to their utilization for the public service, industry, and agriculture.

2. Giving advice upon applications for concessions for water-power plants and upon proposed articles of concession, with a view to the ntilization of the water and power for the public service or by properly anthorized companies.

This commission shall be composed of (1) one counselor of state, president; (2) five legal advisers, viz, from the department of public works, the director of roads, navigation, and mines and the director 
of railroads; from the department of agriculture, the director of agriculture and the director of agricultural hydraulics; from the dopartment of the interior, the director of departmental and communital administration; (3) two members of the general council of bridges and roads and two members of the commission of agricultural hydraulics; (4) two "maîtres des requêtes" (member's of the council of state next in rank to counselors); (5) two electrical or railroad engineers; (6) the chief engineer of bridges and roads, secretary.

The members of the commission, other than the legal advisers, shall be named by decree. The legal members, in case of absence or other interference with their duties, shall be represented by one of the members of their department, designated by the competent minister. If all the interested officials do not concur in an opinion of the waterpower commission, decision shall be rendered by decree of the council of state.

Article 17. Public administrative regulations shall determine all necessary measures for the execution of this law, and especially the forms in which applications for concession shall be presented and examined, the arrangement of meetings of interested local services for their consideration, and rules concerning the operation of the commission provided in article 16 .

Article 18. All laws and regulations contrary to this law are hereby repealed. 


\section{CHAPTER IV.}

\section{LAWS PROPOSED IN THE FRENCH PARLIAMENT.}

\section{LAW PROPOSED BY M. ALBERT LEBRUN, FOR REGU- LATING HYDRAULIC PLANTS ON NONNAVIGABLE WATERCOURSES. $a$}

\section{LEGISLATION NOW IN FORCE.}

All water-power legislation in France rests on the distinction established by the civil code and confirmed by a century of jurisprudence-that is, on the distinction between navigable waters, which belong to the public domain (article 538 of the civil code) ${ }^{b}$ and nonnavigable waters, none of which are included in the public domain.

Of the navigable watercourses the nation has entire disposition. It grants under rental permission to take water, to occupy lands with a view to irrigation, or to erect hydraulic plants; but these permits are of precarious tenure and revocable withont indemnity, a feature that sometimes constitutes an obstacle to the utilization of the water, so that a modification of the law is therefore desirable. Such a modification is even now under consideration by the commission on publie works.

If a project has the character of a public utility, it may profit by the government concession. Thus was organized, under the special law of July 9. 1902, the Society for Motive Power of the Rhone, which, by ntilizing the waters of the river, supplies light and power to a group of Lỵonnaise communities.

Nonnavigable waters are governed under articles 644 and 645 of the civil code, which read as follows:

Artew: 644. Anyone whose property borders on a watercourse, other than that declared part of the public domain by article 539, may use the water in passige for irrigating his property. Anyone whose property is traversed by this watercourse may also use it as it passes through his land, provided he returns it to its regular channel on issuance from his property.

a Report of commission appointed to examine a proposed law regulating water powers on nonnavigable watereourses, Chamber of Deputies, 9th legislature, session of 1908.

b Highways, roads, and streets under the control of the State and navigable rivers and streams are considered part of the public domain. 
ArTicle 645. If a contest arises between proprietors to whom these waters may be useful, the courts, in giving judgment, must reconcile the interests of agriculture with the property rights; and in all cases the individnal and local regulations conceruing the course and usage of the waters must be observed.

The law of April 8, 1898, sanctioned in article 3 a usage which was long discussed, but which was established long ago by jurisprudence:

Article 3. The bed of nomnavigable watercourses belongs to the proprietor of the two banks. If the two binks are owned by different proprietor's, each one of them owns one-half of the bed, following an imaginary line traced down the middle of the watercourse, sare and excepting contrary title or limitation.

It is plain from the above provisions that the owner of the bed of the river has the right to use the running water which traverses or borders his property. The nature and extent of this right have long been under discussion, althongh they have been established by law. It is admitted that "the proprietor of only one bank may use the water as well as he whose grounds are traversed by the stream, not only for irrigation but for industrial purposes, provided always that he does not divert more water than he could use for irrigation." (Statement of grounds of complaint.)

This right of usage is justified by the risks to property arising from proximity to a watercourse subject to rise and overflow and also by the obligations entailed. Maintaining clear channels is one of the obligations of the riparian owner, and in case of nonperformance by the parties responsible the work is done officially under the direction of the hydranlic service and the costs, charged to the fund for departmental cooperation, are then recovered from the recalcitrant proprietors. 'The expense of cleaning varies from year to year, ranging between a million and a half and two million franes.

Riparian rights being thus defined, what is the method of procedure for regnlating hydranlic power on a nombrigable watercourse?

The riparian proprietor who possesses the full rights to a fall of water, whether owned by original right or acquired by amicable purchase, requests a permit from the achministration. For a long time this permit was granted by virtue of the law of Angust 12-20, 1790, the government decree of 19 Ventose, year VI, and in conformity with the circulars of October 23,1851 , and December' 26, 1884. 'Today the law of April 8, 1898, defines the matter in articles 11 et seq.

Article 11. No dam or other work destined for the establishment of a canil regulator, mill, or factory can be constructed on a nomnarigable watercourse without the authorization of the Government.

A decree dated Angust 1, 1905, determines the details of the application of the law.

But this anthorization is not of the same nature as the concession or permit granted for a stream forming part of the public domain. 
It can not be granted except for reasons of public interest and is more in the nature of a police measure. For example, the Government ascertains whether the flow of the water, the security of the riparian inhabitants, and the public health will not be injured by the projected enterprise. It does not inquire, however, what use the petitioner proposes to make of the water or whether such or such a riparian dweller will be injured by the work in question.

For this reason this anthorization is given subject to the rights of the third party; and the courts have the power to appraise the damages that might result. This power of decision may go so far as to demolish works which are considered too injurious to the interests of a riparian inhabitant.

In addition, the Government can withdraw an anthorization previously given for these same police considerations, as is indicated in article 14 of the law of April 8, 1898:

Permits may he revoked or modified without indenmity, either for considerations of public health or to prevent or check inmudations, or finally, in cases of general regulation, as provided in article 9 . In all other cases they can be revoked or morlified only on condition of indemnity.

In the interests of agriculture, the laws of April 29, 1845, and July 11,1847 , created an aqueduct and dam service for irrigation in the following terms:

Law of A pril 29, 18,5.-ArTicle 1. Any proprietor who wishes to use for the irrigation of his property the natural or artificial waters over which he has the right of disposil may obtain passage of these waters over the intervening property by paynent of a just indemnity in advance. Honses, comts, gardens, and inclosmres pertaining to dwellings are not included in this provision.

Law of .July 11, 18, \{.-Article 1. Any proprietor who wishes to use for the irrigation of his property natural or artificial waters over which he has the right of dispesal may obtain the right to place on the property of the owner of the opposite bank such constructions as are necessary for the collection of the water by payment of a just indemnity in advance. Inuldings, courts, and gardens pertaining to dwellings are not included in this provision.

It is proposed to extend the benefit of these provisions to industry, as the latter is not less important to the general welfare than agriculture.

\section{REVIEW OF PROPOSED IEGISLATION FOR PRIVATE POWER PLANTS.}

There are two points on which all these measures agree; one is the giving to public plants the right to sell their surplus power to private industry; the other is the extension of the privileges conferred on irrigation enterprises by the laws of 1845 and 1847 to reservoirs and dams constructed for industrial purposes. But if there is agreement on a few points, there is wide divergence on some fundamental questions. The measures relate to two diametrically opposed principles, and 
from 1898 to 1904 caused long and heated discussions between their authors, in which all concerned in the utilization of "white coal" were vitally interested.

The first bill is by M. Jouart, deputy, and bears date of March 3, 1898. On July 6, 1900, it was followed by a bill brought in by Messrs. Baudin and Jean Dupuy. Both provide for the direct intervention of the nation in the creation of waterfalls-at least of those exceeding 100 horsepower-by means of concessions analogous to the concessions for public works. The Baudin-Dupuy measure proposes that such concessions shall be limited as to term and be subjeet to redemption after a certain period; further, that they shall be subject to forfeiture in case of failure to comply with any of the prescribed conditions. The bill further provides that on the termination of a concession the property and appurtenant improvements shall revert to the nation unless the concession shall be extended by agreement, in which case the former concessionnaire has the right of preference over eventual competitors. No right of indemnity is granted to riparian owners who are deprived of water rights and privileges that they have not utilized.

This bill has been widely eriticised; first, by riparian owners, who claim that the rights assured to them under article 644 of the eivil code have been ignored; second, by industrial concerns which are antagonistic to the nation's interference in purely private enterprises; and, third, by those who, although not directly interested in the hydraulic industry, oppose the abandonment of the ancient legal principle that distinguishes waters of the public domain from those of private possessions.

*

*

$*$

*

$*$

*

:

Answering this criticism, other proposals were made providing for the least possible intervention of the nation and the maintenance, with slight modifications, of previous legislation. In this elass may be mentioned especially the so-called "congress of Grenoble bill," drawn up by M. Michoud, in which the several riparian dwellers, having rights over the same fall, are treated as coproprietors of a property and are permitted to divide up their interests by a system of legal licitation, allowed under article 815 of the civil code. This licitation takes place in the ciril courts, and the sum paid by the purchaser is distributed among the proprietors on a pro rata basis. The purchaser may then with entire security request administrative authorization under the law of 1898 . Under a somewhat similar system, supported by Messrs. Hanuiou and Ader, liquidation of riparian rights is accomplished by a kind of licitation which is of an administrative rather than a judicial eharacter, as appeal is made to the laws of 1865 and 1888 relating to the constitution of corporate associations. In this the majority of the riparian owners constrain the minority 
to agree to pooling their rights in order to create a waterfall, and to acquiesce in the sale. The remuneration is then equitably distributed, as in the case cited above. These bills tend to extend to the limit the rights of riparian dwellers and to reduce to a minimum the nation's power of intervention.

In June, 1903, the minister of agriculture organized a commission to study the measures necessary "to insure a better utilization of the water power of nonnavigable streams." This commission was so constituted that all interests were represented. It included members of the council of state, civil and government engineers, lawyers, manufacturers, etc. The conclusions of the commission formed the basis of the bill laid before the Chamber January 15, 1904, by M. Mongeot, then minister of agriculture.

This bill and others of the same kind were studied and discussed until, in 1907, the present commission submitted the following bill, which in the judgment of its members incorporates the best features . of its predecessors:

\section{THE PROPOSED LAW.}

SECTION I.

\section{Private hydraulic plants.}

Article 1. Private hydraulic plants on nonnavigable watercourses are divided into two classes.

The first class comprises those which are subject only to legislation anterior to the present law.

The second class comprises those which have benefited by the provisions of the present law under the conditions stipulated in articles 2 and 3.

Manufacturers have the choice of remaining under the régime of existing legislation or of asking to benefit by the provisions of the present law.

Article 2. If a factory desires to benefit under the provisions of the present law, an express request to this effect must be filed, either at the time of the request for authorization of the work, or subsequently if the matter concerns a factory already in existence.

The petitioner must indicate the sections of the banks to be affected by the retention of water by the dams or by the projected deflection of water for use in the factory.

He must prove that he possesses (1) the land necessary for the establishment of the factory; (2) one of the banks required for the site of the projected dam; (3) the riparian rights for at least onethird of the total-length of the banks in the section concerned, not 
including in the calculation of this third those parts belonging to the public domain of the nation, the Departments, or the communes.

Article 3. The demand is subject to an examination, whose forms are the same as those of the investigation preseribed by article 12 of the law of April 8, 1898.

It is decided by decree in council of state whether the request shall be granted or denied; it being denied if the conditions necessary to obtain the permit provided for in the law of April 8, 1898, and the present law have not been fulfilled, or if the investigation develops objections that the council of state deems valid.

The permit is barred by limitation if a part of the work, specified in the decree, is not executed within a period of three years after the issuance of the decree. It may always be withdrawn by decree in council of state if the conditions prescribed in the act of authorization, under application of article 6 hereinafter set forth, for the protection of the general public, have not been or cease to be complied with.

Arricle 4. When a request for the establishment of a new plant has been filed, competing requests, comprising either in whole or in part the sections of watercourse included in the first request, may be framed under the same conditions as those prescribed for the first. It shall be the duty of these petitioners to notify all preceding petitioners of these requests.

When there are several competing requests for the same fall, preference shall be given to that petitioner who shall prove possession of the largest fraction of riparian rights.

When the requests relating to different sections of the same watercourse are partly competitive, the preference shall be given to the enterprise contemplating the largest production of power, provided the difference in its favor, under average conditions of utilization of the works to be established within a period of three years, as provided in the preceding article, amounts to not less than one-fifth.

When the right of preference can not be determined by either of the preceding regulations, preference shall be determined by priority of demand.

Anticle 5. The request for authorization, as provided in the preceding articles, may be filed by a free association of riparian owners, organized under the laws of June 21, 1865, and December 22, 1888. Such association can not be transformed into an authorized association.

The corporation thus organized may cede temporarily or finally its rights over a fall or factory. Its manager has the right to determine for the members the reserves of water in kind, the restitutions of motive power, and the money indemnity, observing always the regulations as set forth in articles 8 et seq. of the present law. He shall distribute among the parties concerned all proceeds resulting from 
the cessions mentioned above, save and except when recourse is had to the civil courts.

The statutes determine the procedure in these various operations.

Article 6. The act of authorization for hydraulic works determines the precautions to be taken for the protection of the general public, especially those concerning the public health, protection from inundation, alimentation of riparian owners, needs of irrigation, conservation and free circulation of fish, and protection of the landscape.

It may contain restrictions relating to the restoration of water in kind at specified points of the section in the interest of enterprises designed to supply nonriparian communities or collective irrigation. These restrictions are mull and roid if the project to which they relate has not been approved within a period of two years from the date of the act of authorization, or if, after being approved, the work is not executed within a period of three years from the date of the approval.

During the first ten years immediately succeeding the beginning of operation of the factory, any public authority may requisition for the public service it administers a portion of the converted or unconverted power not exceeding one-fourth at low water. This requisition is authorized by a decree setting forth the reasons therefor, rendered in council of state on the report of the minister of agriculture and of the ministers of the departments having jurisdiction over the public services concerned. The requisition is executory only on payment of a preliminary refund of a corresponding quota of the expense of establishment, maintenanee, and exploitation of the works or apparatus used for the service making the requisition, or on payment of a corresponding rental fee, if the requisition is temporary.

The Govermment shall have the power to make requisition, under the same conditions, for a quota of the increase of power at low water produced by works constructed under the terms of the present law, with a view to increasing the capacity of a factory erected before the promulgation of the law.

In case of litigation the sum to be refunded or the rental fee is determined by the civil court on the testimony of experts.

The Government may renounce in whole or in part its right of requisition for a supply of power at a fixed price, agreed upon with the manufacturer. The modifications of the right of requisition and the contracts for the supply at a fixed price shall be approved by a decree in council of state on the report of the minister of agriculture and of the ministers of the departments having jurisdiction over the services concerned.

Article 7 . Permit is given under reserve of the rights of third parties. 
The interested parties may lay before the civil eourt their demands for reserve or restitution of water in kind, for restitution of motive power, or for indemnity.

The judge, in giving sentence, must reeoneile the interests of property with those of agrieulture and industry.

He may order that a provisional indemnity shall be paid by the manufacturer before operation of the injurious work begins.

Ho will be guided, however, by the following regulations:

Article 8. For preexistent irrigation or reservoirs of water for domestic supplies the parties interested may demand free restitution of the water in kind. Reciprocally, the manufacturer has the right to discharge this obligation by making this restitntion, or by indemnifying, when necessary, each one of the interested parties for the expense entailed on him by the conditions resulting from the utilization of this water.

By exeeption, and when he has not been notified by the deeree of authorization of the express restrictions required by the needs of irrigation, the judge may decree, on payment of indemnity, the diminution or suppression of existing irrigation the maintenance of which would involve excessive difficulties, if the construction of the projected work is elearly of greater importance than the individual enterprises obstrueted.

For rights of irrigation and domestic supplies of which no nse has been made prior to the request for a permit for the works, the judge will decide whether and in what measure the individual claim for reserve in kind should be allowed, or whether the rights involed should be satisfied in whole or in part by a money indemnity. 'The manufacturer may always discharge his obligations to the holders of these rights by furnishing the amount of water in the natural state necessary for their property bordering on the watercourse, under the conditions and at the price they themselves would have had to pay formerly with works using only simple gravity. these conditions and this price to be determined by experts in case of disagreement.

Article 9. The right of riparian owners to the use of water for other purposes than irrigation and household purposes is transformed into right of indemnity.

Nevertheless, if there are preexistent motive powers in the sections of the watercourse affected by the construction of the projected waterfall, the manufacturer must restore to those having rights over such powers, if such exist, all the power of which they have had disposal. This restitution may be made in the form of electric energy, with indemnity for transformation if neeessary.

Those having these rights may, if they prefer, give up their right to restitution of the power in kind in exchange for indemnity. 
For restitution of power in the form of electric energy, cited above, the manufacturer may secure rights of way for pole lines, etc., as provided in article 12, paragraph 3 , of the law of June 15, 1906, conferred on the concessionnaire of an enterprise for distributing electric power which has been declared a public utility.

Article 10. The factories established under the terms of the present law have the benefit of the aqueduct and dam service as regulated by the laws of April 29, 1845, and July 11, 1847. On payment of a just preliminary indemnity they also have the right to occupy the bed of a watercourse and to submerge the banks by raising the water level.

Nevertheless the owners of the property injured by these services have the right to require the manufacturer to purchase the land submerged as well as the sites necessary for the construction of the works or of surface or underground canals.

The proprietor may compel the manufacturer to construct all the works necessary to insure communication between all the parcels of land traversed.

All disputes arising from application of the terms of this article are under the jurisdiction of the civil court.

\section{SEC'TION 11 .}

\section{IIydraulic plants declared a public utility.}

Article 11. Hydraulic plants may be established by virtue of a declaration of public utility and may be made the object of a special concession when their principal object is to insure the supply of power necessary for the public services of the nation, the Departments, the communes, and syndicates of communes, or for authorized associations and other public institutions.

Artrcle 12. The declaration of public utility is made and the concession is approved, after due investigation, by decree in council of state on the report of the minister of agriculture and of the ministers of the departments having jurisdiction over the services concerned.

The declaration of public utility, however, is made by a law passed after investigation by and on the advice of the council of state, when the works relate to the deflection of waters from their natural beil over a line of not less than 20 measured kilometers following the bed.

The concession may be granted, with power of reconveyance, to Departments, communes, and syndicates of communes.

Article 13. The conditions under which the concession is granted specify (1) the services for which the factory is established and the conditions under which they are to be served; $(2)$ the duration of the concession; (3) the works, lands, buildings, and engines of all kinds which constitute the dependent realty of the concession; (4) the reg- 
ulation of the water of the factory, especially measures relating to public health, protection from inundation, domestic supplies of the riparian population, needs of irrigation, conservation and free movements of fish, and protection of the landscape; (5) the rights and obligations of the concessionnaire, both during the time of the concession and at its expiration, and regulations relating to redemption of the concession and forfeiture, if there should be any.

The conditions must be conformable to the type approved by decree in council of state. Every derogation made therein shall be expressly mentioned in the act of concession.

Article 14. Modifications may be made in the uses of the power, as specified in the statement of conditions, on the demand of the concessionnaire and by virtue of decrees giving the reasons therefor, rendered in council of state after investigation.

In addition, there is at all times liberty to sell and nse the surplus power and the residues of exploitation.

Contracts made under the terms of the preceding paragraph will remain valid in case of the return of the factory to the grantor for any cause whatsoever for a period specified in the statement of conditions.

Anticle 15. At the expiration of the period determined the concession, with all its dependencies, as specified in the statement of conditions, reverts to the nation without indemnity.

During the ten years preceding the expiration of the concession a new concession may be obtained. Conditions being equal, the concessionnaire in possession has the right of preference.

If, five years before the concession expires, no new concession has been granted, the concessionnaire may demand a prolongation of his concession for another ten years, under the same conditions as the first.

The same provision applies five years before the expiration of each new period of ten years.

Article 16. Factories declared a public ntility have the benefit of the services mentioned in article 10 of the present law. There is also a general benefit resulting from the right-of-way privileges granted by article 9 to private factories subject to requisition for the restitution of power in kind.

The expropriation necessary for the establishment of factories of public utility is effected under the conditions provided for in the last five paragraphs of article 16 of the law of May 21, 1836. If, however, there is question of expropriating lands on which there are buildings, the law of May 3, 1841, alone is applieable.

Article 17. The decree of concession determines the indemnities which may be allowed, if there are any, for deprivation of the riparian rights held under article 644 of the eivil code in all cases in which effective use thereof has not been made, 
Article 18. The factories declared of public utility and their dependent realty, as defined in the statement of conditions, are classed as public domain. Their works are classed in the same category as the works dependent on the commission of public roads, ways, canals, etc., especially as regards punishment of transgressions.

Transgressions are liable to a fine of 16 to 300 franes ( $\$ 3$ to $\$ 55$ ).

Article 19. Factories forming an integral part of enterprises declared a public utility, such as railways, tramways, public lighting and power systems, etc., benefit under the terms of articles 10, 14, and 18 , hereinbefore set forth. The other provisions of the present law can be applied to them only by modification of the act of concession, approved under the same forms as the act itself. In default of modification thus approved, they remain subject to the same régime as the rest of the enterprise of which they form a part.

SECTION III.

Collective works for the improvement of the regularity of flow of watereourses.

Article 20. The execution and maintenance of works designed to improve the regularity of flow of watercourses with a view to industrial and agricultural utilization may give rise to the organization of free corporate associations. These associations may be converted into anthorized associations by application of article 8 of the laws of June 21, 1865, and December 22, 1888, provided the conditions of majority, prescribed by the statutes, are fulfilled.

Article 21. Proprietors of lands and factories who are not members of the association but who would profit directly by the improved regularity of flow of the watercourse can be compelled to pay to the association, when converted into an authorized association, indemnities, which shall be determined by the council of prefecture, save and except on appeal to the council of state.

Actions for indemnities for plus value can be brought only by virtue of a preliminary authorization granted by decree rendered in council of state. 'The decree may decide that the indemnities shall be payable in annual installments, taking into consideration every year the utilization made of the additional water or motive power resulting from the works.

Article 22. The proprietors of lands and factories which would profit directly by the improvements in the regularity of flow of watercourses made by the works of the nation, the Departments, the communes, or their concessionnaires and by authorized corporate associations may be compelled to pay indemnities for plus value under the conditions laid down in article 21 . Actions for indemnity can be 
brought only by virtue of a special anthorization, granted, on proposal of the minister of agriculture, by the act which declared the works a public utility.

\section{SECTION IV.}

\section{General provisions.}

Article 23. An order of public administration will determine the measures necessary for the execution of the present law. This especially applies to (1) the papers to be sent with the request, as set forth in article 2, and also the procedure to be followed to file the request and to fix the date thereof; $(2)$ the method of verifying the execution of the work within the period prescribed in article 3, and the forms by which this period may be prolonged in case of delay due to obstacles beyond human control; (3) the method of notification and examination of competing requests, the limits of time within which modifications of requests under examination may be considered with a view to determination of preference; (4) the method of verification of the limitations set forth in the second paragraph of article $6 ;(5)$ forms of the examination to be made of modifications relating to the uses of the power from factories of public utility under the terms of article 14; (6) forms under which the interested parties shall be admitted to plead their claims to the indemnities provided for in article 17.

\section{LAW PROPOSED BY M. BAUDIN AND M. MILIERAND FOR REGULATION OF HYDRAULIC POWER PLAN'TS ON WATERCOURSES AND CANALS OF THE PUBLIC DOMAIN. $a$}

\section{DIGEST OF THE GOVERNMENT PROPOSAL.}

Two kinds of power plants are recognized-(1) private power plants, the energy of which is used exelusively for the industrial needs of one special establishment and affects only private interests; (2) public power plants, which are veritable factories of energy destined to furnish power and light to a whole distriet and which are therefore of public utility.

The separation of the two kinds of plants is well defined in practice. Unless the public sale of power is intended by those operating power plants, the Government must grant a permit for the use of the water. Under the present rule this permit is precarions, as the plant, according to the interpretation of the law by the state comneil, can be subjected to restrictions and regulations made in the interests of the public, and the owner can be compelled to render special services

a Report of the commission of public works. M. Pierre baudin, deputy, Chamber of Deputies, Ninth Legislature, extra session of 1908 ; supplement to the report of the meetIng of December 17, 1908. 
for the benefit of the public; but if he has received no aid from the Government and has been left to his own resources in the establishment of his plant, he nevertheless remains a free agent. After meeting his obligations in the form of taxes, he need account to no one for the power that he derives under the permit.

As soon, however, as power is offered for sale, the character of the power plant changes completely. It becomes a public utility and its functions must not be hampered by private interests. The grantee is no longer a private user of power for industrial purposes, but in the operation of his plant he is subject to government regulations which may be productive of results not specifically beneficial to his private interests, but which are justified by public policy.

Certain conditions and limitations may be specified in the permit and a special tax may be levied to regulate the conditions under which the service may be used. In other words, exclusively private interests become abolished or become secondary to public interests. A third party, namely, the public, is introduced into the arrangement, with power to appeal to the courts for adjustment of grievances. Finally, there remains to be considered the interest of the concessionnaire, the value of whose property may be decreased and whose profits may be reduced by the application of the regulations prescribed.

\section{CRITICISM AND JUSTIFICATION OF THE NEWLY PROPOSED IAAW.}

The commission does not object to the legal place assigned to public power plants. It acknowledges that the proposed system by which private power plants shall be governed would, in large degree, do justice to collective interests. But the character of the private plant, as proposed in the bill, in itself justifies certain reservations and criticisms. If the question should be decided entirely on the legal principles involved, the commission would recommend the absolute abolishment of private power plants.

It should not be forgotten that a permit to take power from a river belonging to the public domain involves a concession of public property. The legal phase of the transaction is therefore not influenced either by the amount of power granted nor by its final disposition. Such a concession certainly reduces the amount of possible public benefit that could be derived from a watercourse. The Government must therefore not only provide that the grantee shall not derive an excessive benefit from this concession, but must insure for itself, in return for the concession, certain gurranteed benefits, spectfied in the articles of concession. ${ }^{a}$

a In Switzerland, where private watereourses are an exception, the system of concession is applied to all power plants of the public domain, as the use of public watercourses for the development of energy constitutes a sovereign right of the Government. 
The commission recommends the system of concession for all water-power plants located on watercourses belonging to the public domain, without distinction between private and public power plants. To permit the establishment of private plants on such watercourses without concession would involve the abandonment, without compensation, of a very important portion of the public domain. Private plants are far greater in number than public ones and represent in the aggregate an enormous horsepower. The commission believes that the framer of the bill under consideration did not, in his proposal to allow private plants to be established without concession, take into account the inconvenience which the system of simple permits for such plants would produce. The following quotation from the Goverument's own dissertation will support the view of the commission:

Whenever the demand for a grant is made (for private plants) the Government must provide that the compliance with such demand does not injure national or public interests, nor werent or delay the development of public power plants. In all decisions by the Government preference must be given to public interest.

From this declaration it becomes evident that the idea of government control is dominant, and that without provisions for concession on the public domain such control can not be exercised.

The government representatives, in their conference with the commission, have acknowledged the justice of these observations, but they have also pointed ont eertain difficulties which would result in practice if the law as suggested by this commission were strictly enforced (meaning the concession for all power plants on watercourses of the public domain).

It was mentioned that if the formalities necessary to the establishment of government control were required from small plants, the procedure would be entirely out of proportion to the importance of the establishments. In addition, the Government would be required to exercise control over a multitude of inferior establishments when its attention should be concentrated on the more important questions of the development of private property. It was also pointed ont that under a concession covering a certain term, the owner would be entitled to damages if it were found necessary during that term to confiscate or to damage the plant for any purpose of public benefit. The concession could not be terminated before the expiration thereof except by forfeiture and redemption. Under such conditions, would it seem advisable to increase the already large number of small power plants, which are now useless for public service and which will in the future surely prove to be an obstacle and an unnecessary expense to the Government, if for any reason said Government should be com- 
pelled to change the regulations on watereourses on which any of these small plants might be located?

The commission acknowledges the necessity for modifying the concession. It has included in the Baudin proposal a distinetion between types of power plants, based on the value of the power in the different watercourses of the public domain. It is not proposed to exempt permanently from the requirements of concession all small power plants, but the commission's recommendations affect those whose present and prospective connection with exelusively industrial private interests is beyond dispute. The question of future utilization is more important than that of present consistency of legal procedure. Every contract having for its purpose the sale of power, of whatever amount, must be placed under concession. This rule will therefore be applied to two kinds of hydraulic establishments-first, powerplant concessions based on the amount of power produced, and second, concessions based on the use to be made of the power.

For the large number of small power plants and for some of those of medium size, the permit system is proposed.

Mention should be made of the joint meetings of the commission and the representatives of the power industry, who have approved the new legislation and have made certain suggestions. The commission had already foreseen some of these suggestions and had provided therefor. It should be understood that neither the executive nor the legislative branch of the Government intends to enact any measure that will inhibit the growth of industry. Without. framing a general rule which will meet all unexpected difficulties, the administration must fix the duration of the concession aceording to the importance of the plant and the amount of capital invested. At the expiration of any concession, preference should be given to the former grantee in making a renewal.

\section{THE PROPOSED LAW.}

\section{SEC'TION $\mathrm{r}$.}

Classification of poucer plants.

Article 1. Hydraulic power plants established on the public domain shall be classified as "anthorized power plants" and "power plants under concession."

Anticle 2. "Authorized power plants" shall be defined as those which develop a gross energy of not more than 250 horsepower at low water, and which have not for their principal purpose the sale of power. All other power plants shall be designated as "power plants under concession." 
SECTION II.

Authorized power plants.

Article 3. Authorized power plants shall be governed by laws and regulations now in force. All authorizations are subject to cancellation, and they shall not in any case be granted for a period longer than fifty years. At the expiration of that period the grantee shall, if the authorization is not renewed, restore the premises to the condition previously existing or deliver the power plant to the nation without indemnity therefor, as the nation shall elect.

Article 4. In the case of power plants now in existence, the fiftyyear period fixed by the preceding article shall begin from the time of the passage of this act.

Article 5. The surplus power of any authorized plant may, under exceptional conditions, be sold to the public under regulations promulgated by the minister of public works.

SECTION III.

\section{Power plants under concession.}

Article 6. All concessions for power plants shall be limited to a specified term and shall be made the subject of articles of concession, conforming to one of several types approved by decree of the state council, with modifications and conditions which shall be expressly specified in the articles of concession.

The concession shall be granted in the name of the nation by decree rendered in the form of a public administrative regulation. In case the project necessitates the diversion of water from its natural course for a distance greater than 20 kilometers, measured along the river channel, or if the capacity of the proposed plant is greater than 18,750 horsepower, no concession shall be granted except by enactment of a special law in Parliament.

Subsequent regulations concerning the use and distribution of the hydraulic power shall be promulgated by decree of the state comncil, after inquiry.

Provided, That the foregoing requirements shall not apply to power plants which constitute a component part of an enterprise declared to be of public utility, which shall be subject to special regulations determined by decree of the state council.

Article 7. The concessionnaire shall be invested with authority to execute the works defined in the articles of concession, together with all the rights which the laws and regulations confer upon the administration in the matter of public works, and said concessionnaire shall in turn comply with all the obligations imposed upon the administration by such laws and regulations. 
In case of expropriation, the procedure must conform to the law of May 3,1841, in the name of the nation and at the expense of the concessionnaire.

Article 8. The holder of a concession for a power plant shall have the right to occupy private property necessary for the storage of water and for the establishment of underground conduits supplying water to the power plant and conducting it therefrom, in conformity with the terms of the concession as approved by the administration.

Such occupation of private property must be preceded by notification to all parties interested and by special inquiry held in each of the communes where the aforesaid works are to be established.

Indemnities accruing from such occupation shall be regulated in the first instance by the civil tribunal ; if appraisal is necessary, the tribunal shall name but one appraiser.

Article 9. The articles of concession for power plants shall specify-

1. The location of the plant.

2. The duration of the concession.

3. The works, lands, housing, and equipment of erery kind constituting the stationary appurtenances of the concession.

4. The amount of water to be used by the power plant, and particularly provisions for its regulation so as to avoid damage to navigation and to afford protection against floods, to safeguard the public health, to conserve the interests of the people in the matter of water supplies and irrigation, to protect and provide for the migration of fish, and to preserve the natural beauties of the landscape.

5 . The amount of rental to be paid to the nation for the use of the water and the obligations incurred in connection with works previously established by the nation for purposes of navigation, if any, together with all other financial conditions imposed by the concession.

6. The amount of sureties.

7. The maximum charges for the sale of power to the public.

8. The amount of water or power to be reserved for the benefit of public services and the conditions under which it must be placed at public disposal.

9. The methods of national control and provisions for the expense thereof.

10. Conditions under which the right of redemption may be exercised by the Government.

11. The rights and duties of the concessionnaire, in general, both during the concession period and at its expiration.

Article 10. All the improvements comprised in the power plant, including the real property and rights of way occupied by it, as 
specified in the articles of concession, shall become a part of the public domain and shall be subject to police regulations in the same manner as are the public roads, for violations of which there shall be imposed penalties of 16 to 300 franes (about $\$ 3$ to $\$ 55$ ).

Article 11. At the expiration of any concession for a power plant the nation shall immediately take possession of the plant and appurtenances constituting a part of the public domain, as defined in the preceding article, without liability for indemnity.

Article 12. All power plants which have, in whole or in part, been declared of public utility, and those under concession which do not have for their principal purpose the sale of power, may at all times dispose of excess power not utilized in the regular operation of the plant, under conditions fixed by the state comcil, on report of the minister of public works.

Article 13. Power plants already in existence, anthorized under precarious and revocable title, and disposing of a gross primary horsepower in excess of 250 horsepower, or having for their principal object the sale of power, must within a period of five years from the date of passage of this act be placed under concession, by decree.

SEC'TION IV.

\section{General provisions.}

Article 14. Watercourses, or parts thereof, including canals of the public domain, to which this act shall apply are (1) those specified in the schedule accompanying the order of July 10, 1835, classified in conformity with other orders subsequent thereto; (2) those classified as a part of the public domain at the completion of works declared of public utility or following acts of redemption. Such watercourses and parts thereof and canals shall not be separated from the public domain except by enactment of law.

All claims based on rights acquired on watercourses under paragraph 1 of this article shall, under penalty of forfeiture, be instituted within one year from the date of passage of this act.

Article 15. The rental accruing to the nation from anthorized power plants or those under concession shall conform to article 44 of the law of April 8, 1898, and to regulations made or to be made in execution of that law. By such regulations shall be fixed the special conditions governing rentals applicable to plants established on the canals of the public domain.

Article 16. Administrative regulations, based on report of the minister of public works, shall cover-

1. Form of water regulations for authorized power plants.

2. Form of articles of concession. 
3. Forms for plans and specifications covering projects and their approval.

4. Procedure to be followed in connection with the various inquiries relative to concessions and authorizations for power plants, and in the establishment of rights of way.

5. Rules for national supervision of porrer plants under concession, the cost of which shall be borne by the concessionnaire.

6. General regulations covering the sale of surplus power, as provided in articles 5 and 12.

7. In general, all necessary measures for the execution of this act. Anticue 17. This law shall not apply to power plants already in legal existence.

Article 18. All laws and regulations in contravention of this act are hereby repealed. 


\section{CHAPTER V.}

REVIEW OF THE WORK OF THE BUREAU OF HYDRAULICS AND AGRICULTURAL IMPROVEMEN'TS OF THE FRENCH DEPARTMEN'T OF AGRICULTURE. ${ }^{a}$

\section{ORGANIZATION OF THE BUREAU.}

\section{FUNCTIONS.}

The water's of France, in their legal status, are divided into two distinct eategories. Rivers navigable by ships or rafts form a part of the public domain and, if used principally for transportation, are under the control of the minister of public works. Watercourses navigable neither by ships nor rafts and springs, underground waters, etc., do not form a part of the public domain and are, according to their nature, subject to the more or less extended rights of the private individual. Their control is rested in the ministry of agriculture, which adopts and enforces measures designed to enhance their importance for agriculture and domestic supply. ${ }^{b}$

The policing, conservation, and management of these waters are under the control of the hydraulic service, a branch of the bureau of hydranlics. This burean has been under the ministry of agriculture since its organization in 1881.

In 1903 the bureau was organized under the name of the burean of hydraulics and agricultural improvements, and its duties and importance were considerably increased by adding to the hydraulic service the new office of "agricultural improvements:" The manifold functions of the latter were established with a view, on the one hand, of insuring a better utilization of the waters by agriculturists, and on the other, of improving land for various rural enterprises.

Until 1903 the Government had limited itself to giving assistance to enterprises pertaining to agrienltural lyydraulics by granting sub-

\footnotetext{
"Circular of the department of agriculture.

"The total length of waters navigable by ships or rafts in France is abont 7,950 kilometers (about 4,956 miles); the length of those not so navigable is about 270,000 kilometers (about 167,670 miles).
} 
sidies for this purpose to corporate associations, ${ }^{a}$ by undertaking the study of the most interesting projects of this nature, and, if the work was of very great importance, by having it supervised by government agents.

But such government assistance was always strictly limited to important canals and drainage works, the utilization of the water conducted to private properties being left entirely to the initiative of the individual. The result of this was that the farmers, left to their own devices and lacking the necessary knowledge and experience, failed to profit as much as was expected from the expenditures of the Government. Agricultural utilization of the waters did not develop as was hoped. The agricultural improvement service was created to remedy this condition by the organization of a technical force composed of agronomic engineers who would guide the syndicates and landholders in the rational management of the irrigated lands, in the choice of crops best suited to the soil, and in the practice of irrigation. It is also the duty of this service to study, in cooperation with the agents for roadways and bridges, the economic effects on agriculture of the great hydranlic works. It cooperates with interested parties in making various improvements on the land (drainage, making the land salubrious, construction of farm roads, ete.) and in every sort of enterprise pertaining to rural engineering (farm buildings, dairies, distilleries, etc.).

The reorganization of the bureau of hydraulics and agricultural improvements has increased its usefulness by inducing a better agricultural utilization of waters and by enlarging its sphere of action.

\section{PERSONNEL.}

The bureau of hydraulics and agricultural improvements comprises two distinct branches:

In the Departments ${ }^{*}$ the hydraulic service is organized from officials of the office of bridges and roads (engineers in chief, engineers, superintendents, and clerks), under the direction of the inspectors general of the agricultural hydraulics. For the execution of any large work or for a very important study, special branches of the service may be organized from the office of bridges and roads, detached from the ministry of agriculture. Finally, special clerks for agricultural hydraulics are employed in Departments where the hydraulic service has a great deal of work to do:

The agricultural improvement service comprises an inspection force vested with the control and examination of projects before they

a The syndical [corporate] associations, which were established by the laws of June 21, 1865 , and December 22,1888 , consist of groups of proprietors interested in the same enterprise of public interest. These associations can, under certain conditions and after complying with certain formalities, benefit under the statute of public utility.

${ }^{b}$ Administrative districts into which the French Republic is divided. 
are submitted to the higher administration, a force of engineers in charge of territorial districts to make studies and draw up plans, and a force of technical agents to aid the engineers in their studies and in supervision of the works. In addition, professors of agriculture cooperate with this service in all things relating to agricultural research. Within the limits imposed by the necessities of their regular duties, they also aid the engineers and technical agents in the study and preparation of plans, and in the supervision and control of works.

\section{COMMISSIONS.}

To aid the administration in its examination of matter's which have been studied by the Department services, a commission on hydraulies and agricultural improvements has been organized in connection with the bureau for the purpose of giving advice on technical and administrative matters submitted by the minister for examination. Reports are laid before this commission either by the inspectors general of hydraulics or by the inspectors of agricultural improvements, according to the nature of the matter.

In addition, two other commissions are charged with the verification of the accounts of the irrigation and drainage works to which the Government has granted an interest guaranty. A special commission decides on requests for subsidies to communal works for supplying drinking water, of which we shall speak later.

In conclusion, a decree of March 31, 1905, created in the bureau a committee to promote, coordinate, and centralize research on the numerous scientific problems relating to the improvement of the soil, and notably questions pertaining to the following subjects:

Physical and mechanical properties of the soil and their relation to their geologic origin.

Irrigation-the composition, action, and use of irrigating water.

Agricultural utilization of the refuse and waste waters of industrial establishments.

Research, selection, and culture of the best botanical species for introduction and propagation on irrigated land, poor and uncultivated soils, peat or boggy land, salt lands, and others to be improved.

Meteorology and agricultural physics.

The application of machines and motor's in works of agricultural improvement and the utilization of electric power in agriculture and rural industries.

A second decree of December 26 of the same year, with a view of developing the study of hydrology, increased the membership of the committee and especially charged it with the study of the relations existing between precipitation and surface and underground run-off. Included also were the investigation of the various influences 
affecting stream flow and the best methods of utilizing them for the development of power. The programme further embraced the examination of various questions relating to the circulation of undergromnd waters and the regularity of springs, with a view to facilitating the utilization of their waters for public supply and laying the foundations for new legislation to insure good use of the hydraulic wealth contained in the subsoil of the national territory.

The foregoing remarks deseribe the organization and functions of the bureau of hydraulics and agricultural inprovements. We shall now take up in detail the different functions of the branches of this bureau.

\section{THE HYDRAULIC SERVICE.}

FUNCTIONS.

The functions of the hydraulic service are manifold and complex, by reason of the diversity of government work, whose purpose it is to insure the best possible utilization of water in the interest of the general public. The Government uses various means to perform its mission effectually. It endeavors to encourage individual initiative and at the same time to prevent injury to the general public and even to the individuals. Where a projected enterprise is clearly for the public good, the Govermment takes the place usually assumed by private individuals.

The Government exercises this intervention throngh the hydraulic service, especially in policing, conserving, and controlling waters which do not form a part of the public domain.

The polieing of the waters includes the removal of obstructions to the flow of water in channels by regular dredging and cutting of weeds and the regulation of the power and diversion dams to the end that floods shall be prevented and that no injury shall be done to the public water supplies, public health, and other general interests downstream. It also includes measures to prevent damage by pollution of waters by industrial wastes.

The Government intervenes in the adjudication of conflicting elaims to water supply for agriculture and other industry, when the interests demand it. To insure the proper control and utilization of waters, the Government grants subsidies to defray the cost of conservation works undertaken by communes or corporate associations. The principal operations subsidized under these conditions are works of irrigation, reservoir and dam construction, drainage, channel rectification, bank protection, and the removal of silt deposits. Protection works are subventioned, even when the protection is from watercourses belonging to the public domain or the sea, whenever the agricultural interests involved are of sufficient importance to justify the intervention of the department of agriculture. 
Finally, projects for municipal water supply constitute a special category of subsidized enterprises. Formerly, the subsidies were restricted to rural communes having a population of less than 1,000 inhabitants. The law of March 31, 1903, however, provided that a tax of 1 per cent should be levied on the total amount of money wagered at the race tracks, the proceeds to be used to subsidize communal projects to supply drinking water, with the restriction that this subsidy shall not be granted to cities where the value of the "centime" (municipal tax) exceeds 1,000 franes (abont $\$ 200$ ). The amount of the subsidy allowed in the execution of this law is determined by a computation based on the fiscal obligations of the commune and the per capita expense of the work. All subsidized enterprises must be approved by the minister of agriculture, who makes streh modifications in the plans submitted to him as he deems neeessary to insure their effectiveness. The execution of the work is under the control of the hydraulic service.

But the Government does not confine itself to subsidizing corporate associations. It undertakes, of its own motion, important works or those presenting special technical difficulties, and instructs the hydraulie service to take up studies that it consider's useful or that have been requested by the communes or corporate asociations. Generally a part of the expense must be borne by the parties interested. The hydraulic service, by suggesting the proper legislative measures and by pursuing the necessary studies and researches, endea vors to develop every method of utilizing waters likely to prove of benefit to the public. Thus it took up the modification of the law of June 21, 1865, relating to corporate associations, and the law of December 22, 1888, enacted through the efforts of the service, extended the benefits to a number of enterprises not included in the first law. The later law also changed the conditions relating to the majority necessary to constitute a corporate association. It facilitated the creation of associations to be organized for the purpose of executing works for the improvement of the soil, irrigation, drainage, etc. In effect, the law of 1865 required for the formation of these societies the unanimous consent of all the parties interested; the law of 1888 permits the majority to orerrule the minority, provided the object of the association has been declared a work of public utility by the council of state.

In another line of effort, the hydraulic service has endeavored to encourage the development of hydro-electric porver and its application to agricultural and other industrial purposes. Although nulmerous and important factories, rum entirely by "white coill," have been erected for some years in the mountainous regions, notably among the Alps, it is recognized that measires must be taken to encourage their further installation. 'To this end on January 15, 
1904 , the minister of agriculture laid before the Chamber of Deputies a bill relating to power plants on nonnavigable streams. This measure was designed to facilitate the control of these watercourses, and also the utilization of their latent energy, while respecting the rights of riparian proprietors and the interests of irrigators.

A force has been organized to prepare an inventory of the unutilized resources of the watercourses in the Alps and the Pyrenees, and to seek methods of exploiting them. This hydrologic study is to be generalized and extended to the rest of the territory in order to amplify and improve previous studies of the volume and regularity of nonnavigable streams. Investigation will be made of the extent and regularity of subterranean waters and the flow of springs fed by them. These researches, which are important because of the daily increasing use of such waters for domestic supply, will form the basis of new legislation relative thereto.

The following review gives some idea of the principal work done by the hydraulic service and fittingly complements the preceding statement of its functions.

\section{NOXIOUS WATERS.}

\section{DRAINAGE AND SOIL IMPROVEMENT.}

Works of this nature are designed to improve the public health and to substitute cultivated fields for areas covered with water. These fields are usually very fertile, especially when irrigated. Works of this kind are usually constructed by the concessionnaires or by corporate associations, but many operations of considerable importance have been undertaken or are now projected by the Government.

Among the drainage works undertaken within the past thirty years may be cited the draining of the Fos marshes (Bouches-du-Rhône), and among the projects soon to be undertaken the draining of the pool of Arnel (Hérault).

Among the principal enterprises for soil improvement fully executed or terminated since 1870 must be mentioned the moors of Gascony (Gironde et Landes), covering an area of 800,000 hectares (3,088 square miles); the Sologne (Loiret, Loir-et-Cher, Cher) extending over 500,000 hectares (1,930 square miles); the Dombes (Ain), 112,700 hectares (435 square miles); and the Double (Dordogne), 50,000 hectares (193 square miles). Works for the improvement of the plain of Forez (Loire), which has an area of 60,000 hectares (232 square miles), are now in course of construction. This enterprise includes the building of an irrigation canal, which will enhance the value of the reclaimed lands.

The Government has contributed largely to defraying the cost of all these enterprises. The work has remarkably ameliorated the 
conditions of human life in these regions and has at the same time greatly increased the territorial wealth of the country. Take, for example, the moors of Gascony; the average price of the land per hectare has risen from 65 to 270 francs $(\$ 13$ to $\$ 54)$; the average length of life, formerly 34 years and 9 months, is now 39 years, a higher a verage than that for the whole country. The pines of Landes, which cover immense tracts of improved lands, have added to the wealth of the country by the commerce in timber, resin, etc., to which they give rise. The general well-being is increased and there has been a notable growth in the public revenues.

In Sologne the moors, which were formerly uncultivated, are today covered with woods over an area of more than 250,000 hectares (965 square miles). Since the beginning of the works the population of Sologne has increased 20 per cent, while that of neighboring regions has grown only 10 per cent. In the Dombes country, formerly the most unhealthful region in France, the work of improvement has resulted in diminishing the ferer cases by five-sixths. Similar results have been obtained on the plain of Forez, where, thanks to irrigation, land values have increased enormonsly.

There is one enterprise now projected and soon to be begun, if Parliament grants the necessary funds, with which, so far as the results to be obtained are concerned, only the improvement of Landes can be compared - that is, the drainage of the east coast of Corsica. This is a vast project, which includes the filling up and clrainage of insalubrious marshes and pools and the improvement of the months of rivers. This work is to be completed by the construction of a system of canals for the conveyance of good drinking water, so indispensable to the health of the communes interested. When the work is completed we may expect a transformation of a region now devastated by malaria extending orer more than 100,000 hectares (386 square miles).

CLEANSING AND STRAIGIITENING WATERCOLRSES.

These operations, which are necessary to insure the free flow of waters and which have considerable influence on the salubrity of river lands, are particularly delicate and require the constant attention of the hydraulic service. The importance of the work accomplished is demonstrated by the length of the streams annually cleaned, which extend over more than 13,000 kilometers (8,080 miles) and drain an area of more than 420,000 hectares (1,622 square miles). Sometimes it is necessary to complete the work of cleaning and weed cutting by straightening and deepening the channel. As an instance we may point to the work recently done on the Conie (Enre-et-Loir), which covered more than 150 kilometers (93 miles) of the river. 
DAMIS AND PROTECTION OF BANKS.

This work, by which lands of great value are preserved and brought under cultivation, serves also in certain cases to protect dwellings. The work is done by corporate associations, with important subsidies from the Government. The most important enterprises of this nature have been completed in regions exposed to the ravages of torrents, such as the Jura, the Pyrenees, and the Alps.

But it is not only against river waters that we must protect cultivated lands. The sea also commits depredations, and important dike work has been undertaken to restrain its incursions. In this connection the repair of the dikes encircling the salt marshes of Guerande may be cited. This great enterprise, which has cost not less than 300,000 francs (about $\$ 56,000$ ), will preserve to the salt industry an important area, which was menaced by the encroachments of the sea.

\section{USEFUL WATERS.}

\section{IRRIGATION AND SUBMERSION.}

The hydraulic service has directed its efforts principally to the development of irrigation of lands not bordering on rivers. Such lands can be watered only by the construction of irrigation canals. These are built either by corporate associations or by associations of concessionnaires. The Govermment subsidizes such enterprises, leaving, however, a large part of the expense to be borne by those interested.

Since 1870 eight large irrigation canals have been constructed, with a delivering capacity exceeding 1,000 liters per second (35 secondfeet). Twelve more large canals were projected and are now completed or about to be completed.

In addition to canals for watering the land must be mentioned those for the submersion of vineyards, constructed in the Department of Aude between 1880 and 1890, after the invasion of phylloxera. These canals are designed to enable the vine grower to keep his vines under water in winter to a depth of 30 or 40 centimeters (0.98 to 1.31 feet) for a period of forty to sixty days. The canals of Aude serve a vineyard area of 11,000 hectares (42.5 square miles), of which 7,225 hectares ( 27.9 square miles) have been submerged since the completion of the work. 'They were built by the Government at a cost of more than 5,000,000 francs $(\$ 1,000,000)$ and were first put under the charge of the corporate associations interested, but were finally transferred to them entirely on condition of the payment in annual installments of two-thirds of the cost price advanced by the treasury.

The irrigation canals proper are situated in the arid region of the southeast. Irrigation alone render's possible truck gardening and 
the culture of fruits and flowers, which are shipped as far as Paris. Flowers for perfumery are cultivated on a large seale in the Departments of Var and Alpes-Maritimes. The market for aromatie flowers in the city of Grasse owes its importance wholly to the proximity of the Siagne canal.

Finally, the service will study the question whether it will not be profitable to extend irrigation projects in certain regions by pumping water to fields not susceptible of irrigation by gravity canals. It is possible that, by selling the surplus power thus obtained, water can thereby be supplied for agricultural purposes at a price more commensurate with the returns from the land.

\section{INCREASING THE REGULARITY OF STREAM FIOW.}

In the Midi, where irrigation is especially well developed, the volume of the streams is frequently insufficient in the dry season to meet all the requirements of irrigation. Although the quantity of water allowed to each irrigator has been reduced to bare necessity, it frequently happens that the lack of water brings ruin to agriculture. This distressing condition is remerlied by the construction of reservoirs in the more elevated parts of the valley in which considerable quantities of water are stored up in times of plenty for use when the dry season sets in. These works are important for another reason. By regulating the volume of the streams, they increase the available water power in the streams below.

Among the operations of this kind is included the regulation of the volume of the streams flowing from the platean of Lannemezan (upper Pyrenees). This regulation is accomplished by means of a canal which draws water from the river Neste. Is the Neste was not of sufficient volume to assure at all times a sufficient flow in the canal. the Government had to supplement its volume artificially. For this purpose the lakes of Oredon, Caillaonas, Ammar, and Cap de Long. situated in the Pyrenees, have been transformed into reservoirs. During the dry season the waters from these lakes are diverted into the Neste.

\section{MUNICIPAI, WATER SUPPLIES.}

As has been said above, undes the law of March 31, 1908, a tax of 1 per cent is levied on the money put up in wagers under certain conditions, and from the sums thus collected subsidies are granted to communes who apply for them for the construction of aqueducts for drinking water. The applications for subsidies are submitted to the special commission mentioned above, which approves them after a thorough investigation of the projects by the agents of the hydratulic service. This examination covers several entirely distinct subjects. 
First, the hydranlic service must ascertain under what conditions and with what restrictions the contemplated conveyance can be authorized, in order to determine whether it shall or shall not be subsidized. This is indispensable, as by law the rights and interests of all nsers of the water's from which the supply is to be derived must be safeguarded. Also, the engineers of the hydraulic service are required to verify every detail of the enterprise; to see whether the plans are technically correct and well adapted to accomplish the end in view; and, finally, to determine whether the work is planned as economically as possible." After these data have been obtained in the field the bureau of hydranlics and agricultural improvements submits the projected enterprise to its technical adviser's for another examination. If advisable, it takes the necessary steps to have the enterprise declared of public utility, and finally gives to the commission on subsidies a full and clear statement of all the facts.

The subsidies are paid to the communes in installments proportioned to the expense actually incurred, after it has been proved that the work has been properly done and that no modifications have been made in the plans whereby their value might be impaired.

After the experience of three years we may safely assert that the law of March 31, 1903, has resulted in a considerable increase in commumal enterprises for the conveyance of drinking water, and that the effect on public health has been most gratifying.

\section{REGULATIONS FOR FACTORIES.}

The number of factories annually regulated is large, abont 580 . In recent years this regulation has been particularly important because of the increased number of large factories using much power. The operations of these establishments greatly influence the regularity of the streams and necessitate the building of very high dams. In addition to supervising the conditions affecting the flow of the water and the health of the community, the administration, by virtue of its police powers, sees to it that the structures are so strongly built that all danger therefrom to dweller's downstream is removed.

\section{THE IGRICULTURAL IMPROVEMENTS SERVICE.}

By the terms of article 1 of the decree of April 5, 1903, cited above, the principal improvement works which the service has undertaken are as follows: (1) Agricultural utilization of waters; (2) drainage and improvement of the soil; (3) redistribution and exchange of parcels of lands and farm roads; (4) construction of rural buildings, small agrieultural industries, and other land improvements.

\footnotetext{
a In addition to their duty as supervisor's, the engineers of the service are at the com mand of the communes to prepare, on request as communal engineers, all plans for the installation of domestic water supply.
} 


\section{AGRICULTURAL UTILIZATION OF WATERS.}

At present most farmers confine their efforts to constructing canals, ditches, etc., and do not interest themselves sufficiently in the rational management of the surfaces irrigated or in the distribution of water in conformity with seasons and crops. They do not introduce sufficient system into their irrigation work. As each farmer irrigates at will his own parcel of land, sometimes uselessly and often at cross purposes with his neighbor, they frequently obtain poor results, entirely disproportionate to the expense incurred, and waste, to their own and to others' injury, the water at their disposal. In order to avert such misuse, the agricultural improvements service acts as guide to the farmers. It prepares the plans for the proprietors or syndicates, and in this way completes the work of the hydraulic service. This aid is given not only to cultivators desiring to utilize the waters supplied by the linge irrigation canals, but also to those who wish to make direct use of the small streams. Some idea of the importance of this work may be realized if we note that after deducting from the water in our rivers the amount necessary for food and domestic purposes, sufficient volume remains to irrigate $12,000,000$ hectares (46,320 square miles), putting the irrigation at 15,000 cubic meters per hectare ( 4.92 acrefeet per acre) a year, the generally accepted average. In this connection it may be remarked that the little streams which the farmers can use directly are of considerable importance. Those having an average length of 2 to 5 kilometers and a basin of not more than 2,000 hectares ( 7.7 square miles) represent about 85 per cent of the watercourses of our country.

\section{DRAINAGE AND IMPROVEMENT OF THE SOIL.}

The theory and practice of drainage have made important progress in recent years, and the methods of subterranean drainage, invented about the middle of the last century, have also been much improved. The art of the drainer at first corered a few practical rules, but it has gradually developed until now we have a fairly complete system which enables us to substitute rational processes for old empirical methods. These processes have become more definite and economical and insure constructions of almost limitless duration: Under these conditions it is evident that drainage to-day constitutes a special art. possessing its own peculiar technique and requiring deep study and preliminary apprenticeship. The study of such projects, as well as the supervision and direction of the works, has been intrusted to the agricultural improvements service.

Special privileges relating to the flow of waters were granted to drainage enterprises by the law of June 10, 1854. Another law of 
July 17, 1856, brought in by the Government, appropriated the sum of 100,000,000 franes $(\$ 20,000,000)$ for loans to drainage works. By the terms of an agreement concluded April 28, 1858, between the minister of finance and the minister of agriculture and Crédit Foncier, the latter assumed the burden of these loans. The loans, bearing 4 per cent interest, are payable in twenty-five annual installments of 6.41 per cent of the sum, the borrower having the right to pay back the whole or a part at any time during that period. The payment of these installments is secured in the same manner as are the direct taxes. To cover these loans the Crédit Foncier has a lien on the crops and the right to take a mortgage on the drained lands. Ordinarily the Crédit Foncier contents itself with a mortgage without haring recourse to the formalities necessary to insure its rights.

This legislation in faror of drainage enterprises is justified by the importance to agriculture of this form of land improvement. According to a report made in the name of the superior commission on the control of waters, organized in 1879 in the ministry of public works by M. de Freycinet, there were in France not less than 4,000,000 hectares (15,440 square miles), which could be drained to advantage. The area was probably even larger, as a statement contained in the law of April 17, 1856, estimates it at not less than $9,000,000$ hectares $(34, \tilde{i} \pm 0$ square miles).

\section{REDISTRIBUTION-FARM ROADS-REMAKING THE CADASTER.}

The agrieultural disadvantages resulting from the parceling ont of the land into small units caused the Government to take up the question of redistribution. The minister of agriculture summarized the advantages which would result from combining these small parcels, as follows: Economic employment of improved implements, impossible of use on separate small units of land; easy supervision of cultural operations; easy access to roads; independence of neighbors in the distribution of crops; facility of transportation; easy determination of boundaries; simplification of the ground plots of property; reduction of the cost of cultivation; possibility of cooperation in drainage, irrigation, dams, and straightening watercourses; repair of roads, etc.

Free exchange was facilitated by the law of November 3, 1884, which in certain cases reduces the proportional dues from 6.7 franes to 0.20 franc per hundred (\$1.34 to 4 cents). But these isolated exchanges are by no means so important as a general rearrangement of boundaries, which can be accomplished only by the corporate associations, established in conformity with the laws of June 21, 1865, and December 22, 1888. It is to be hoped that the passage of the law of March 17, 1898, which was completed by the decree of June 9, 1898, and of the fiscal law of April 13, 1900, articles 19 to 21, 
designed to hasten the revision of the cadaster, will enable us so to profit by this operation that the improvements hitherto described may be made at very little expense. Certain modifications must be made in existing laws to secure full benefit from the measures already passed by Parliament. The organization of the agricultural improvements service in the ministry of agriculture is a long step toward this accomplishment. The work is further aided by the agreement of 1904 with the office of direct taxes, through which the cadastral service and the agricultural improvements service can cooperate in the necessary operations.

From now on the agricultural improvements service will engage in systematic construction of farm roads, which will not diminish the land parcels, but will minimize the disastrous consequences of the parcel system. These roads can be built at a moderate cost, and the work entailed can be put under the control of free or commissioned corporate associations. The advantages that would accrue are as follows: They will supply outlets for the land parcels, thus giving right of way to both the principal and the dependent properties, and by so doing removing a pregnant cause of vexations and lawsuits. They will open to cultivation closed-in lands, which have been left uncultivated because of the impossibility of cultivating at the desired period. Finally, they will enable the intelligent farmer to cultivate when and as he wishes and give him freedom in the distribution of his crops.

\section{RURAL BUILDINGS.}

The construction of farm buildings and the erection and management of industrial establishments as an adjunct to the farm necessitate an ever-increasing fund of special knowledge which is rarely possessed by any one person. In fact, the people usually engaged in putting up farm buildings are not progressive, either in France or elsewhere, and are not in touch with the improvements in agricultural industries and industrial equipment. At this time, when new methods of culture and economic necessities often render imperative a complete change of agricultural equipment, the small farmers find the agricultural improvements service an invaluable aid. They can call in the aid of this service whenever they want to utilize the power of a waterfall for the generation of electric power, and apply the energy to numerous agricultural uses, such as the lighting of farm buildings and the operation of various agricultural apparatus, such as thrashing machines, crushers, grinders, churns, saws, etc.

This use of electricity in many cases transforms farm operations and facilitates the development of small rural industries.

The service also render's very important aid in the construction of cooperative buildings. The small farmers, who by force of circum- 
stances are compelled to resort more and more to cooperation in farming operations, need establishments of a truly industrial character. Very often when a question arises concerning the erection of a building and its interior arrangement they lack the knowledge to estimate the expense involved and the profits to be derived and to make the necessary plans. They can call on the service, however, to study and prepare the plans, and thus they receive the moral and material support they need. These projects relate to dairies, cheese dairies, distilleries, caves, cellars, granaries, refrigerating plants for farm products, and all other cooperative establishments.

\section{IMPROVEMENT OF POOR OR UNCULTIVATED LAND.}

Waste lands, moors, pasture commons, heaths, marshes, bogs, etc., cover a considerable area in France, amounting, according to the agricultural statistics of 1892 , to $6,226,185$ hectares, or 11.77 per cent of the total area and 12.336 per cent of the agricultural land. Forestation is the only possible method of utilizing a large part of this area, especially the rocky soil and mountain lands. Other lands, on the contrary, such as moors, heaths, marshes, ete., can be made valuable by drainage, clearing, breaking up, etc., and by the building of roads to permit transportation of the necessary fertilizers and other important adjuncts to agriculture.

We may mention, in the category of lands capable of agricultural utilization, peat soils proper, to which must be added a large number of more or less peaty pockets formed by vegetation whose decomposition is not sufficiently advanced to form real peat. Such deposits are found everywhere, especially in the granitic soils of the Vosges, Morvan, the central plateau, Brittany, etc. These lands, if given the proper drainage and cultivation, would in many localities give large returns.

There are difficulties in the improvement of another kind of soil, the salt marshes. The agricultural improvements service has several times had to take up the very complex problem of bringing Camargue under cultivation, this island in certain places requiring methodical desalting in addition to improvement by drainage.

\section{MISCELLANEOUS IMPROVEMENTS.}

In addition to the works enumerated above, we must mention among the subjects engaging the attention of the agricultural improvements service the agricultural utilization of refuse and residuary waters from industrial establishments, the water supply of farms and rural exploitations, the construction of cables for facilitating or rendering possible the exploitation of land difficult of access, etc. 


\section{METEOROLOGY.}

The bureau of hydraulics and agricultural improvements has under its charge all functions pertaining to agricultural meteorology. It subsidizes various meteorologic stations and interests itself particu. larly in the use of ordnance as a protection against hail, which is becoming a general practice throughout France. It grants subsidies to associations organized for protection against hail, frost, and other inclemencies of weather injurious to crops.

In spite of the increasing confidence of the rural population in the efficiency of ordnance as a protection against hail, the effectiveness of this method has not yet been fully established. Very diverse engines are used for this purpose, namely, cannon, rockets, bombs, petards, and many others, all of which have their partisans. The committee of the bureau of hydraulies and agricultural improvements is studying the subject scientifically and making experiments to determine the value of this method of defense and the relative value of the various engines used. 


\section{CHAPTER VI.}

\section{WATER-POWER LEGISLATION IN THE UNITED STATES.}

By M. O. Leigiton.

\section{FEDERAL STATUTES AND POWERS.}

\section{EFFECT OF THE DESERT-LAND ACT.}

The authority of the Federal Government over waters within the United States is of two kinds-by right of sovereignty and by right of proprietorship. The sovereignty is generally believed to be limited, except in the Territories, to the right to use designated streams and watercourses for purposes of "commerce. Such limited sovereignty was given to the United States by the eighth section of Article I of the Constitution. All things necessary to the maintenance and improvement of navigation of these waters are subject to the absolute control of the Federal Government, but with this the sovereignty apparently ceases. This point is, however, not well settled. There is considerable disagreement as to the limitation that may be placed upon the scope of the commerce clause. It is contended by a few that the authority is confined to the local adjustment and control of navigable channels, while other's hold that the control extends to the uttermost tributaries in a drainage area, if such control is necessary to the regulation of the channels actually used for transportation. The latter appears to be the view of the Supreme Court of the United States. (United States $v$. Rio Grande Irrigation Co., 174 U. S., pp. 690-710.)

The authority of the Federal Government over waters by right of proprietorship persists only where the Government is an actual proprietor of land bordering watercourses, as in the public-land States of the West. It is commonly believed that in such cases the Federal Government is subject, in common with all other proprietors, to state water laws. The waters of the public domain belonged originally to the Federal Government, but the usufruct thereof was conveyed by statute from time to time as the land was settled and sovereign States were organized. The rights of appropriation and use of the waters of the public-land States was conveyed to the people by an act of Congress entitled "An act to provide for the sale of desert lands in 
certain States and Territories," approved March 3, 1877 (Stat. L., vol. 19, p. 377). The part of the act referred to is as follows:

Provided, howcver, That the right to the use of water by the person so conducting the same on or to any tract of desert land of $6 \pm 0$ acres shall depend upon bona fide prior appropriation; and such right shall not excecd the amount of water actually appropriated and necessarily used for the purpose of irrigation and reclamation; and all surplus water over and above sucl actual aplopopiation and use. together with the water of all lakes, rivers, and other sources of water supply upon the public land and not navigable, shall remain and be held free for the appropriation and use of the public for irrigation, mining, and nanufict turing purposes, subject to existing rights.

The effect of this law is set forth in an opinion of the supreme court of the State of Oregon, as follows:

Alluir C. Hough et al. Y. S. A. D. Poiter et al.

Opinion by Mr. Commissioner King.

The jrincipal contention of appellants as first urged was that the court acted without jurisdiction in directing that all persons interested in the lands bordering on Silver Creek, its tributaries and clinunels, be made parties to the suit, and that such action on the part of the court constituted reversible elror. These questions of practice. with matters incidental theleto, were deternined adversely to counsel's contention (95 Pac., 732), and the cause was set down for further argument on the main points involved, principal among which is that of riparian rights, as affected by the act of Congress of March 3, 1ST7, known as the desert-1and act: $i b$. , 752. This question and the points formerly determined were fully discussed at the reargument. After a reconsideration of the questions of practice presented we find no reason to depart from the conclusions annonnced in our former opinion.

We come then to a consideration of the desert-land act, as to its effect upon the parties hereto owning lands upon the streams involved. the rights of each of whom have attacled since the passitge of the act. This confronts us with the legal problem as to whether any are ripilian owners: and, if so, to what extent and what bearing their claims as such have mon the water rights in question.

It has become a matter of history that prior to any laws upon the subject the use of watel was exercised under a custom permitting any person to go upon a stream, or other sonrce of watel supply upon the public domain, and divert water therefrom wherever and whenever needed, provided the use thereof did not interfere with the prior rights of others. In other words, priority in the diversion and use determined the rights of all conflicting claimants. This procedure was encouliaged and acouiesced in by the Government for many years throughout the Pacific coast States, until in recognition thereof the act of Congress of July 26, 1866 ( 7 Fed. Stat. Ann., 1090), was adopted, which provided :

"Whenever, by priority of possession, rights to the use of water for mining. agricultural, manufacturing, or other purposes lave rested and accued, and the same are recognized and acknowledged by the local customs, laws. and the decisions of courts, the possessors and owners of such vested rights shall be maintained and protected in the sinue: and the light of way for the construction of ditches and canals for the purposes herein specified is acknowledged and confirmed **** 
This act constituted a recognition of preexisting rights rather than a creation of any new one, and accordingly recoginized and assented to appropriation of water in contrarention to the common-law rule as to continuous flow: Broder $v$. Water Company, 101 U. S., 274; United States $v$. Rio Grande Irr. Co., 174 U. S.. 690 ; Gutien'es $v$. Albuquerque Land Co., 188 U. S., 545 ; Daris $v$. Chamberlain, 51 Or., -- (98 Pac., -).

Supplemental to the above act, provision was made by Congress July 9, 1870, for incorporating a reservation in faror of such rights in all patents when issued, as follows: "All patents granted or preemption or homesteads allowed shall be subject to any vested and acerned water rights or rights to ditches and reservoirs used in comnection with snch water rights, $* * *$ : " Rev. stat., 2:40. This was followed on March 3, 1875, by what is known as the desert-land act, parts of which, in so far as material to this discussion, are:

"That it shall be lawful for any citizen of the United States, or any person of requisite age "who nay be entitled to become a citizen, and who has filed his declaration to become such,' upon payment of twenty-five cents per acre, to file a declaration under oath with the register and receiver of the land district in which any desert land is sitnated, that he intends to reclaim a trat of desert land not exceeding one section, by conducting water upon the same, within the period of three years thereafter: Provided, hovever, That the right to the use of water by the person so conducting the sime, on or to any tract of desert land of six lumbled and forty acres shall depend upon bona fide prior appropriation: and such right shall not exceed the amount of water actually ippropriated, and necessarily used for the purpose of irrigation and reclamation; and all surplus water orer and above such actual appropriation and use, together with the water of all lakes, rivers, and other sources of water supply upon the public lands and not narigable, shall remain and be held free for the appropriation and use of the public for irrigation, mining, and manufacturing purposes subject to existing rights $* * * ": 19$ Stat. (U. S.), 377; 6 Fed. Stat. Ann., 393.

The title of the foregoing act reads, "An act to provide for the sale of desert lands in certain States and Territories." Being an act of Congress, it is well known that it is not required that the title of the act embrace all its provisions. And, while a different rule prevails in some of the States, it is probably an exception rather than the rule that acts of Congress are limited to matters contained in their title. This being the rule which prevailed in Congress, we have only to look to the body of the act to ascertain its intention. After proriding for the reclamation of arid lands and for the procuring of title thereunder, it will be observed that, in this act, as essential to the reclamation of lands, the water right, when located by the persons taking the land, shall depend upon bona fide prior appropriation. The reason for this is apparent; the object and purpose of the act was by this method to reclaim, develop, and make productive arid lands or those of a desert character, which, as a rule, were nonrijarian.

For nany years it was an open question whether lands througl which streams flowed in the natural channels were subject to reclamation under this act: Sims r. Phalen, 11 L. D., 206. But it was finally determined that snch lands cond be reclaimed where clearly shown to be of a desert character: Honck $v$. Bettelyoun, 7 L. D., 425; Nilson $v$. Anderson, 23 I. D., 139. Considering this feature with the then long-existing conditious in reference to the public lands throughout the West, the reasons for ploviding that the water rights should be acquired under the doetrine of prior appropriation are obvious.

The first act (1866) refers to priority of possession and local customs, rules, regulations, etc., to wbich rules of construction were soon applied, the outcome 
of which depended largely upon whether the decisions were by conrts in localities of a strictly arid nature or in the lumid states. If in a strictly arid section, the doctrine of prior appropriation prevailed; while, if humid, a middle ground, or what is called "the modified doctrine of riparian rights," appeirs to have been the one adhered to and deemed the most condncive to the public welfare. Near the time of the passage of this act conflicts had arisen from the application of the law, as applied to riparian rights, in the arid and semiarid West. In California the effect thereof on riparian rights was involved in much donbt and not fully deternined, wbile in Nerada the noted ease of Vansickle $v$. Haines ( 7 Ner., 249) had been decided, adhering to the common-law rule on the subject. This latter ease, howerer, was subsequently overrnled, since which time the doctrine of prior appropriation has there prevailed: Jones $v$. Adams, 19 Nev., 78 ; Reno S. Works $v$. Stevenson, 20 Nev., 269; Walsh $v$. Wallice, 26 Nev., 299.

The act of 1866 had left somewhat in doubt not only the question of its effect upon riparian rights, but an uncertainty whether it thereby intended to establish a permanent rule upon the subject. And the act of 1870 , requiring reserrations in all patents issned, by inserting a statement therein to the effect that the patents were executed subject to rested and accrued water rights, ete, was evidently intended as a precantionary measure to remove doubts then extant as to the legal effect of any patents subsequently issued, so far as applicable to any rights acquired before the date thereof.

In order, therefore, to remore such donbts and to establish a uniform rule throughout the States mentioned in the act, whereby all appropriations made from streams flowing through public lands over which Congress had power to legislate, after the provisions specifying the manner in which lands taken under the act conld be reclaimed, there was added the clanse:

"And all surplus water over and above such actual appropriation and nse, together with the water of all lakes, rivers, and other sources of water supply upon the public lands, and not navigable, shall remain and be held free tor the appropriation and use of the public for irrigation, mining, and manufacturing purposes, subject to existing rights:" 19 stat. (U. S.), 377.

This reservation of water rights for the benefit of the public was clearly not essential to any of the other provisions of the act. The previous statement contained sufficient to define and protect the rights of those selecting lands under the desert-land act, but the added proviso, or something of similar import, was essential to the establishment of a clear and uniform rule upon the subject as regards all appropriations thereafter to be made from streams or other bodies of water upon the public lands and to which such might be riparian.

The words "shall remain and be held free for the appropriation and use of the public for irrigation," ete., are clearly words of reservation and dedication, and obviously so intended. It is insisted. however, that the linguage quoted is insufficient for either a grant, trust, or dedication; that a grant presupposes a grantee capable of receiving it that it is not a trust because all three essentials necessary to constitute a trust, i. e., trustee, trust res, and cestui que trust, are wanting: that it can not be held to be a dedication, in that the right there alluded to is not an easement but is usufuctuary only, partaking of the nature of real estate-an incorporeal hereditament, analogons to a "profit" in land, in that it depletes the riparian right. It is further observed that a dedication is not a grant and can not arise by grant, since it exists in faror of the entire public, in respect to which it was asserted, as above stated, that it can not become a ginutee. 
A dedication is defined as being in the nature of a gift, imuring to the benefit of the public as a grant, but differing from a grant in that no grantee in esse is necessary to its validity : $9 \mathrm{Am}$. and Eng. Ency. Law, 21; 13 Cyc., 439. It consists of derotion or giving of property for some proper object and in such a manner as to conclude the owner: State ex rel. Sims $v$. Otoe County, 6 Nebr., 129, 133 ; Patrick v. Y. M. C. A., 120 Mich., 1S5. 193.

$A$ "reservation" as here used is something taken from the whole thing, covered by the general terms making the grant, and cuts down and lessens it (or act. under which title to the res from which the reservation may be made) from what it would be except for such reservation: Words and Phrases, p. 6140; Weynand $v$. Lutz (Tex. Cir. App.), 29 S. W., 1097. The latter term applied here; the National Government by its various laws relating to public lands granted to its citizens the privilege of acquiring title thereto. Construing all together as one act, the desert-land act by the language used appears to reserve therefrom to the entire public the right of any citizen after March $3,157 \pi$, to divert, use, and acquire a right in and to the unappropriated waters flowing through, or adjacent to. any lands, thereafter patented, such right to be determined by priority. Reservations of this class may be found in Calhoun Gold Min. Co. $v$. Ajax Gold Min. Co., $2 \tau$ Col., 1 (59 Pac., 607, 615; 50 L. R. A., 209 ; 83 Am. St. Rep., 17) ; Wilcox $v$. McConnel, 13 Peters, 496; Wilson $v$. Higbee, 62 Fed., 723. It would not be seriously questioned that such a reservation might be expressly and effectively made in a deed or other evidence of title. Then when we take into consideration that to determine the extent of the title received through a conveyance of any lind from the Gorernment, whether by grant, patent, or otherwise, we must look into all acts in force in reference to the lands intended thus to be conveyed, to ascertain what interest remains subject to transfer, it becomes manifest that there is no difference in principle between a reservation resulting from an act in force at the time and an express reservation in the instrument itself through which title may be asserted.

It would seem, howerer, that as to what may be the proper term by which any interest thus reserved may be designated, we need not inquire. Nor is it material whether any term has been recognized or established by the courts to cover the privileges and rights reserved or surrendered by the Gorernment to the public, or individuals of which the public is composed. Onr form of government, Constitution, and powers reserved to the Government have necessarily given rise to privileges and rights not fully covered by the common law or by the terms in common use nuder it.

The right of the Government to dispose of its public lands and to deal with all rights incident thereto, in such a manner as it may deem best, has long been fully established and recognized by all decisions upon the subject. True, it can not by legislation determine for any state after its armission what the local laws relative to riparian rights shall be (United States $v$. Rio Grande Irr. Co., 174 U. S., 690, 703), but the General Govermment in dealing with its public lands may provide for their transfer as might any other landed proprietor and make suel reservations therefrom by grant, dedication, or otherwise as it may see fit. Riparian rights may become the subject of a grant or dedication and may be serered from the soil: Coquille Mill and M. Co. $v$. Johnson (Or.), 9s Pac., 132. This principle is clearly and concisely stated in an opinion by Knoeles, district judge, in Howell $v$. Johnson ( $\$ 9$ Fed., 556, 558), al follows:

" Being the owner of these (public) lands, it has the power to sell or dispose of any estate therein or any part thereof. The water (in question; is an innlingable stream flowing over the public domain, is a part thereof, and the 
National Government can sell or grant the same, or the use thereof, senarate from the rest of the estate, under such conditions as may scem to it proper."

Decisions to the above effect are too numerons and too well understood to need extensive citation.

By the homestead and other land acts Congress granted to citizeus of various States and Territories the right at any time hereafter to enter upon the public domain and to select a quantity of land, in the manner there specified, and of thereby securing a home, notwithstanding no certain individual was designated to accept and receive such title. The effect of theso acts was that the grantor of the public lands, the National Government, was to hold these lands in trust for the public, to be acquired by any qualified citizen thereof on compliance with the rules preseribed. Numerous grants in mosenti were also made, to be held in trust by States designated in such grants for any conpany, person, or persons who might construct any wagon or other roads there indicated. For example: A grant was made to the State of Oregon of alternate sections of public lands, designated by odd numbers, three sections per mile, to be selectei within 6 miles of what was, at the time of the passage of the act, an imaginary road between two given points within the state, upon the doing of certain acts thereafter to be performed, thus reserving to the builders, if any there might be, the right to select the odd section desired: 14 Stat. (U. S.), p. 89, c. 174; Calhu $v$. Barnes, 5 Fed., 326; Cnited States $v$. Dalles Military R. Co. (and seven others), 140 U. S., 599 ; s. c. 42 Fed., 351; 55 Fed., 711. Such a road in time became a certainty; and more than thirty years after the passage of the act lands were selected, in reference to which it has been held that npon selection thereof the right thereto relates back to the date of filing the map of definite location of the road, shutting out all intervening claims and settlements, regardless of patents issued to settlers thereon during the meantime-and this, too, notwithstanding such policy was instrumental in holding in abeyance and withdrawing from settlement large tracts of the public domain for more than a quarter of a century: Eastern Oregon Land Co. $v$. Brosman, 147 Fed., S0T. Any settlers on such lands are held to have entered thereon with full knowledge of the law and to have taken them subject to the "contingent interests" in the land of such possible road of such company as might become the beneficiary of the grant: Altsehul $v$. Cittings, 102 Fed., 36, 3s.

Another and more allt illustration is that of the policy of the National Gorermment respeeting ots mineral lands. in regald to which any one acquiring title to any part of the public domaln under the honesteald or under any other act takes such land subject to the exception that he does not acquire title to the minerals known to be therein at the time of entry or of patent, whether located for minerals at the time of the inception of the rights of its grantee or not: 5 Fed. Stat. Ann., 2318, 2319: Cathom Gold Min. Co. $v$. Ajax Gold Min. Co., 27 Col., 1. The minerals may remain unclaimed for many decades, yet the first mineral locator, whether on patented lauds or not (if the land patented was known to contain the minerals at the time of entry), upon full compliance with the law on the subject, may become the owner thereof. The same privilege is extended to the patentee, but, under the law, if he neglect to exercise his rights in this respect, he loses to him who becomes the first locator.

It was in the exercise of a similar prerogative on the part of the Government that there was by the act of 1877 given to the public, or to any individual thereof, the right to appropriate and apply to a beneficial use the waters flowing through its public domain. No linit as to the time in which this right may be exercised is made, except in effect that he who first diverts the water and with due diligence applies it to the uses there enumerated is given the better right thereto. It ean make no difference, therefore, whether it be termed a grant, 
reservation, dedication, trust, or other privilege; this unquestioned power of the owner orer the public domain was exercised, and any one entering upon, and acquiring title to, any part of the public domain after the passage of this act accepted such land and title thereto with full knowledge of the law under which the patent was issued, the import thereof being that this right incident to the soil was reserved by the Government to be held in trust for the public; and that he who first applies the water to a beneficial use shall become the owner of the right thereto; and that the recipient of such title talies it subject to that right, which he, in common with other's of the public, is privileged to exercise. It is elementary that the grantor can convey no greater title than he has. This rule as applied to cases of this nature is clearly and concisely stated in Hume $v$. Rogue River Packing Co. (51 Or.), 92 Pac., 1065, 1067. There the plaintiff was owner of a grant from the State, either directly to himself or by mesne conreyances to others, of all the tide lands bordering unon the river, as well as of all the uplands adjacent to the river above tide water, the title to which was acquired from the United States, and the description of which ran to the meander lines. In discussing this featme, this court, by slater, C., says:

"He has no title by express grant from the State to any part of the bed and stream as such, but he does claim title to the entire bed of the stream at the mouth of the river where, by reason of the shifting of the channel of the river from north to soutl, and rice rersa, and by successive purchases from the State as tide land of the uncovered sands on both sides of the river, his deeds overlap, and apparently, at least, he is, at that point of the river, the owner of the bed of the stream; but this fact, we apprehend, will be of no arail in support of his claim of ownership of the water when flowing over such land, for in any event he could acquire no greater rights thereby than would be given the ordinary and legal effect of such deed by virtue of the statute authorizing its execution and delivery."

It is true that the act of 1870 made it necessary to insert in the patents a reservation of all vested and accrued water righs. rights of way, etc., as well as to make similar reservations in patents respecting minerals: but, as stated, so far as a legal effect of the reservation is concerned, such would have been unnecessary, in that the Government conld grant no greater right than it had. Acts of this nature, like those requiring patents to be issued for lands acquired under railroad and other grants, under which title passes by virtue of the acts granting the lands. are but supplemental legislation. In this manner the evidence of title may more conveniently be placed on record, and thereby add to the convenience, in many respects, of the holder of the title, but otherwise adds nothing thereto: Cahn $v$. Barnes, 5 Fed., 326, 331; Pengra $v$. Munz, 29 Fed.. 830, 8355; Langdeau $v$. Hanes, 21 Wall., 521; United States $v$. Dalles Military R. Co., 140 U. S., 599 ; also cases cited in Rose's Notes (U. S.), rol. 8, p. 466.

A good illustration of the power of the Government or other landed proprietor, at all times and whenever desired by it, to grant, reserve, or dedicite a right to any one at any time to acquire title to all or to any part of its public domain in such manner as it might designate-either to the land itself or to the incorporeal rights alpurtenant thereto, whether an easement over it, the removal of the minerals, of the timber, or of the right to the use of all or any of the waters flowing through or adjacent to such land-may be found in the recent case of United States $v$. Winans, 198 U. S., 371. In that case a suit was brought to enjoin the owners of certain lands on the Columbia River from interfering with the exercise by the Indians on the Yakima Indian Reservation in the State of Washington of fishing rights and privileges over, on, and adjacent to lands along the Columbia River, patented to the defendants therein, 
which rights were chamed under the provisions of a treaty nade in 1859 between the Indians and the Tnited states. This traty reserved to them the exclusive right to fish in all streams rumning on and within certain lands within prescribed limits, and to fish in common with the eitizens of the territory at all acenstomed places in the vicinity. and further secured to such Indians the right of way over all lands necessary for carrying such reserved rights into effect, together with the privilege of erecting on any of the then public lands temporary buildings for the curing of fish. Subsequently the lands between the Columbia River and the special tract set aside and known as their "reservation" were entered by citizens of that State withont reservations therein of any kind being issued to them. Grants from the State of Washington to the shore land fronting the patented lands were also procured by the patentees, together with licenses from the State to mantain devices for taking fish, alled fish wheels. By virtue of these patents, grants, and right thus atequired by the landowners, it was maintained that they conld preclude the Indians from fishing along the shores and from crossing the patented lands for that pmpose. in respect to which it was argned that the Indians, under the rights reserved to them and recognized by the Government in the treaty, acquired "merely an execntory license or privilege, applying to no certain and defined places, and revocable at will of the United States, to fish, hunt, and build temporary houses upon public lands, in common with white citizens. upon whom the law has conferred no title by ocupancy whaterer." These contentions were sustained by the United States circuit court in that State (United States $v$. Winans, 73 Fed., 72, 74), Judge Hanford, inter alia, observing:

"The theory that kunds conveyed by government patents, after being so conveyed and appropriated by individnal citizens, still remain subservient to use and occupation by the Indians for travel over the same, otherwise than by lawfully established public highways and for camping grounds, finds no support in the provisions of the treaty, nor in the rules for the construction and interpretation of statutes, which must be applied in the interpretation of the treaty and of the public-land laws of the United states."

But on appeal to the United States Supreme. Court this decision was reversed (198 U. S., 381), the court holding in substance that. notwithstanding patents were issued to the lands by the Government, the patentees took the same subject to the rights reserved to the Indians thereafter to fish along the shores of the Columbia River, including a right to erect temporary structures for that purpose. and to retain such easements as would enable the privileges thus reserved to be executed. In discussing the effect of the patents the court say :

"The reservations were in large areas of territory and the negotiations were with the tribe. 'They reserved rights, however, to every individual Indian, as though named therein. They imposed a servitude upon every piece of land as though described therein. There was an exclusive right of fishing reserved within certain boundaries. There was a right outside of those bonndaries reserved 'in common with citizens of the territory.' The land department could grant no exceptions from its provisions. It makes no difference, therefore, that the patents issued by the department are absolute in form. They are subject to the treaty as to the other laws of the land."

It is clear from the foregoing decision (1) that whether the landed proprietor be the Government, a tribe of Indians, or other owner, such proprietor may reserve or grant a right or interest in, over, and alpurtenant to or in any mas. ner connected with its lands, not necessinrily to an individual alone, but to a class of individuals in general as well as in particnlar, withont limit as to time, application, and use of the rights or privileges thus reserved, dedicated, or 
granted; (2) and such right or interest in its public lands becomes effective in favor of those for whom it may be reserved or to whom it may be dedicated, and against those subsequently acquiring title thereto, even though such rights may not be exercised until after the lauds shall have been patented to others; (3) and that in so far as the binding effect thereof is concerned upon such subsequent purchasel it is immaterial that such reservations or excep tions are not specified in the patents or other instiuments of conveyance.

Reservations of this class are fully and ably discussed by the supreme court of Fentucky in Rowan's Ex'rs. $v$. Town of Portland, S B. Monroe, 232. The supreme court of New Hampshire, in the case of State $v$. Franklin Falls Co., 49 N. H., 240, 256, declines either to agree with the reasoning of that court or to follow the rule there enunciated; but the United States Supreme Conrt, in Morgan $v$. Ry. Co., $96 \mathrm{U}$. S., 716 , clearly adopts the reasoning applied by the Kentucky court and observes that the consideration there given these questions is a full, able, and correct exposition of the law on the subject, with which conclusion we concur. In Rowan's Ex'rs. $r$. Ry. Co., supra, the dedication related to certain streets adjacent to a stream and included the right of wharfage or right to land boats and other vessels along thit part of the street bordering upon the river. The conrt, in discussing the legal effect thereof, concludes that the grantor holding title subject to the use to which it was dedicated held the title thereto in himself as trustee for the public, which his grantee took subject to such trust; and further observes:

"Whether the public at large was or could be the immediate grantee or recipient of this right we should consider it fruitless to inquire. The potential right of use in and by the publie wals created by the sale and conveyance of the lots. And whether it passed at once to the public, or remained in abeyance, or is the mere result of an estoppel, or rested in the purchasers of lots as a part of the estate conveyed to them, it was in either case alike perfect and beyond the future control of the original proprietor or his alienees of the title on which this right of use was engrafted."

Again, as stated in Pearsall r. Post, 20 Wendell, 111, 119:

"It seems to be well settled by the Supreme Court of the United States, by severil courts in the neigliboring States, to which we may, perlaps, add the court of chancery in this State, that dedicatons of land for religious and charitable purloses, as well is for public ways and squares, commons, parks, and other easements in nature of ways, are to be upheld, although there be no person in csec capable of taking as a grantee at the time. It was remarked by Mr. Justice Thompson. in Cincinmati $v$. White's Jessee, 6 Peters. 429, 436, that the principle. if well founded in law, must have a general application to all appropriations and dedications for public use, where there is no grantee in esse to take the fee.' He adds: 'This forms an exception to the rule applicable to private grants and grows ont of the necessity of the case.' These remarks comprehend every conceivable case where a man has furnished evidence of a clear intent to sive up his real estate for the purposes of any logitimate public usc."

Privileges of this class were not unusual and were recognized as being subject to dedication, in the enrly history of the law upon the subject, as disclosed by further remarks therem of the same court. namely:

"I pass over the more usual instances of easements. such as ways, commons, and water privileges, etc., enjoyed either ly individuals, towns, or other corporations. * * * We may also pass over those which are less common, and one put by Mr. Justice Thompson, in 6 Peters, 437. from McConnell $v$. I Lexington, 12 Wheat., 582, the reservation of a spring of water for public use. It was made to a corporation which might turn the spring to its own or public purposes. Thus, the user was invoked to establish an individual right. A like 
case is mentioned in Co. Litt., 50 a. a customaly watering place in the luhabitants of Southwarke. for violating which an action was held to lie."

In the spring case alluded to it appears that the Commonwealth of Virginia in 1773, by an act known as the land law, reserved 640 acres of land. upon which the spring was situated, for the lonefit of those who had settled in a village or city, afterwards to be laid out into lots and divided among such settlers. The spring was in common use by the inhabitants of a village located on this tract and [was] afterwards claimed by one of the purported grantees of the lot upon which it was situated. The court, however, in an opinion by Mr. Chief Justice Marshall; held that the use of the spring by the public and the recog. nition thereof for a long period of time constituted such a dedication; and that even though the elaimant thereof be considered the grantee of the land unon which the spring was situated. its use for the purposes mentioned. althongh no reservation was made in the deed, must be deened to have been reserved. It may be said that in that case the entire public exereised the right to the use of the spring thus dedicated. but it must be remembered that the exercise of this right was merely by the individuals constituting the public. In the case at bar the public exereises the right in a somewhat similar manner, except on a larger and more extensive scale, in that an alluropriation by any individual or corporation gives it a right in and to the flow and use of the water appropriated for the purposes for which it is diverted. which right mily afterwards be subject to sale and transfer. But it is clear that if a dedication can be made to the public of a spring or a stream in the manner indicated in the last case quoted, the owner of any source of water supply may make a like dedication in that or in any other manner determined upon. 'The mamer of making the dedication, as well as its legal effect, must be determined from the act or instrument by which it is made. In the case under consideration it will be observed that the language used is that the smrplus waters of the streams and of other sources of water supply designated shall remain and be hold free for the appropriation and use of the public for (1) irrigation, (2) mining. and (3) manufacturing purposes. The mamer of appopriating and using the water for irrigation, mannfacturing, and mining purposes was at that time and has been at all times since well understood; hence the use by the public and manner thereof is specitied. meaning. when interpreted in the light of the then existing facts, the usual mamner of applying it for power purposes and of diverting it by means of ditches and other systems in use for irrigation. including also the usual methods in use by miners.

It follows that the rights reserved to the public and dedication of the surplus water's therefor were intended for use in that manner. Construed then with the act of 1866 and other provisions of the act of $187 \%$, we are of the opinion that all lands settled upon after the date of the latter act were accepted with the implied understanding that (except [as] hereinafter stated) the first to appropriate and use the water for the purposes specified in the act should have the superior right thereto.

So far as we are able to determine, the question as here presented has not heretofore been squarely before any of the conrts. But, while not deemed essential to an adjudieation therein, we find the act of 1877 considered to some extent in the following cases: Williams $v$. Altnow (51 Or.), 95 Pac., 200; Farm Investment Co. v. Carpenter, 9 Wyo., 110 ; United States $v$. Conrad In. Co., 156 Fed., 123, 128; United States $v$. Rio Grande Irr. Co., 174 U. S., 690; Gutielres $v$. Albuquerque Land Co., 188 U. S., 545; Kansas $v$. Colorado, 206 U. S., 46.

In the first case mentioned, Altnow, who was the proprietor of the land npon which Warm Springs Creek had its source. chimed both as a prior appro- 
miator and as a riparian owner. To his riparian claim it was maintained as a defense that his lands were settled upon after the date of the desert-land act, for which reason he was not a riparian proprietor in the sense that as such alleged riparian owner he conld assert a right in the stream for irrigation; and this contention was in that case expressly upheld by the trial court. On this point Mr. Chief Justice Bean observes that Altnow's claim as riparian proprietor (all other parties therein being in the same position in this respect) could not he upheld for two reasons: (1) That he relied upon his claim as prior appropriator and was bound by it: (2) that the lands having been entered since the year 1877 , " it is a serious question whether the desert-land act does not abolish the so-called modified doctrine of riparian rights, which gives to riparian proprietors the right to use water for irrigation as to all lands through which nomnarigable streams flow, the title to which has been acquired from the Govermment of the United States since the passage of that act." And after quoting from the act, he further remarks:

"The Govermment of the Tinited States, as the primary owner of the soil, undoubtedy has the right to make such provisions concerning the waters of nonna vigable streams thereon as it deems proper, and it is at least a debatable question whether. by the language quoted, Congress did not intend to recognize and assent to the appropriation of such waters in contravention to the common-law doctrine of riparian rights as to persons subsequently acquiring title from the Inited States. Cnited States $v$. Rio Grande Irr. Co., 174 U. S., 690."

In Wyoming the doctrine of miority of appropriation for beneficial use in contravention to the common-law rule on the subject prevails. By legislative enactment of 1856 the water of erery natural stream in that State was declared to be the noperty of and dedicated to the use of the public. The manner of appropriation and acruilement of such rights are specified, included among which rriority of appropriation for a beneficinl use was declared to give the better right. It is thus evident that without the provisions of the desert-land act the conrt there held and was bound to adhere to that doctrine. But in Farm Investment Co, $v$. Carpenter, 9 Wyo., 110, Mr. Chief Justice Potter, in discussing the question as to whether an express constitutional or statutory declaration was necessary in the first instance to render the streams and other natural bodies of water the property of the public and subject to the control of the laws of the State, without refurence to riparian rights, says:

"If any consent of the General Government was primarily requisite to the inception of the rule of prior appropriation. that consent is to be found in sereral enactments by Congress, beginning with the act of July 26, 1S66, and including the desert-land act of March 3, 1S77. Those acts have been too often quoted and are too well understood to require a restatement at this time at the expense of unduly extending this opinion."

In New Mexico Territory, where the doctrine of prior appropriation also prevails, a similan question to that in the Wyoming case came before the court in Gutierres $v$. Albuquerque Land Co., 185 U. S., 545. The question there inrolved the validity of a territorial act permitting the construction of canals and condemning rights of way, etc, in reference to which it was urged that the territorial act was invalid because it not only assumed to dispose of the rroperty of the United States withont its consent but was in conflict with the legislation of Congress and therefore void. It was there argued that the waters affected by the statute were public and exclusively the property of the United states; but the statute alluded to permitted private parties and corporations to acquire the unappropriated waters in riolation of the right of the Government to control and dispose of its property wherever situated. In con- 
sidering this feature, Mr. Justice White, speaking for the conrt, at page 552 of the opinion, observes:

"Assuming that the appellants are entitled to urge the objection referred to, we think, in view of the legislation of Congress on the subject of the appropriation of water on the publie domain, partieularly referred to in the opinion of this court in United States $v$. Rio Grande Irrigation Co., 174 U. S., 690, 704-706, the objection is devoid of merit. * * * By the act of March 3, $18 \pi$, , c. 107,19 Stat., $37 \pi$, the right to appropriate sueh an amount of water as might be necessarily used for the purpose of irrigation and reclamation of desert land, part of the public domain, was granted, and it was further provided that 'all surplus water over and above such actual appropriation and use, together with the water of all lakes, rivers, and other sources of water supply upon the public lands and not navigable, shall remain and be held free for the appropriation and use of the public for irrigation, mining, and manufacturing purposes, subject to- existing rights.'"

In United States $v$. Rio Grande Irr. Co., the inquiry was as to the navigability of the Rio Grande River and to the effect a proposed dam therein would have on navigation. While it wis there unquestioned that the common-law rule was that every riparian owner was entitled to the continual flow of the stream and that States and Territories had the power to change this rule and to permit the appropriation of the flowing waters for such purposes as they deemed wise, the court states that this power "is limited by the superior power of the General Government to secure the uninterrupted navigation of all streams within the limits of the United States." It was urged in this connection that the desertland act of 1877 also included therein the right to appropriate the waters of any stream, even though the depletion caused thereby should impede navigation. In the opinion the desert-land act, together with that of the acts of 1866 and 1891, are referred to, concerning which the court, by Mr. Justice Brewer, at page 706, comments as follows:

"Obvionsly by these aets, so far as they extended, Congress recognized and assented to the appropriation of water in contravention of the eommon-law rule as to continuous flow. To infer therefrom that Congress intended to release its control over the navigable streams of the country and to grant in aid of mining industries and the reclamation of arid lands the right to appropriate the waters on the sources of navigable streams to such an extent as to destroy their navigability is to carry those statutes beyond what their fair import permits. This legislation must be interpreted in the liglat of existing facts-that all through this mining region in the West were streams, not navigable, whose waters could safely be appropriated for mining and agricultural industries, withont serions interference with the navigability of the river's into which those waters flow. And in reference to all these cases of purely local interest, the obvious purpose of Congress was to give its assent, so far as the public lands were concerned, to any system, although in contravention to the common-law rule, which permitted the appropriation of those waters for legitimate industries."

These appear to be the only eases in which the attention of the court has been ealled to this act, the plain inference from which is that in the opinion of the eminent jurists quoted, the act of March 3,1877 , was such a reservation by the National Government to and for the public and such dedieation thereto of all its rights in and to all the waters flowing throngh its public lands for irrigation, manufacturing, and mining purposes, as to abrogate the modified commonlaw rules npon the subject, in so far as applicable to all lands entered after that date. 
But the effect of the language of the act that "there shall remain and be held free for the appropriation and use of the public for irrigation," etc., we think, while constituting words of reservation and dedication, limits the rights thereunder to the cleprivation of the riparian lands of the water, only, in so far as it may be claimed by the riparians for the purposes there enumerated. One of the rights inseparable from the land has always been that the owner of such land was entitled to an adequate supply of water flowing over it for domestic use, together with sufficient for the domestic animals necessary for the proper subsistence and maintenance of the landed proprietor and his family. This necessary use, no doubt, gave rise to the doctrine of riparian riglits in the earliest development of the law upon the subject, followed by requirements for navigation, next extended to include the right to its use for power purposes, and later to the production of such garden and grains as were essential to the subsistence of the family of such riparian owner. At first the right of all riparians was evidently restricted to the demands upon the stream for the first purposes named. Lastly, as civilization progressed and extended orer the semiarid sections throughout the different nations, the riparian demands accordingly became more extensive and enlarged to include irrigation. but limited at first. no doubt, to the watering of such garden and other produce reasonably necessary for the riparians' domestic consumption, and as the strictly arid localities became populated, by reason of the correspondingly increased commercial, agricultural, and mining development, this right was finally extended to include the irrigition, not only for the limited purposes mentioned, but to the watering of large areas in the production of grains and other agricultural products, together with its expansion thereof to include all its present uses.

The language used in this act was clearly intended to change the rule lespecting the right of riparians to the use of water for irrigation, mining, and power purposes; but as in the last case cited it has its limits. It does not go so far as to affect the rights originally giving rise to the doctrine of riparian rights, that is, for domestic use, including the watering of domestic animals and such stock as may be essential to the sustenance of the owners of lands adjacent to the streams or other bodies of water. And as held in the last case cited, although abrogating the common-law rule on the subject, the act was not intended to permit appropriators to deplete the flow to such an extent as materially to impair the navigation of the rivers to which such streams directly or indirectly may be tributaries. The reason for this is plain; to permit an interference with navigation would be to deprive the entire public of a valuable right which at all times has been recognized as paramount to that of the individual desiring such interference; while to permit an appropriation of water depriving the owner of the land through which it may flow of its use for irrigation affects such person only. So far as the Government may be concerned by the depletion of a particular tract of land of such benefit, if any, it is recouped by the reclamation of a like tract for which the diversion causing the injury may be made.

Howerer, it can not be presumed that it was the intention of Congress to render the soil absolutely worthless by drying the lands by diversion of the waters flowing through them to nonriparian lands as to leave the soil without the water essential to the owner's domestic needs. Presumably the best possible results for all concerned were intended, which it is clear could best be obtained by permitting the settler to retain the quantity of water essential to the sustenance of his family and to other natural wants incident thereto, but if he does not see proper to apply it to any of the uses specified in the act, then to permit the first home builder on other lands to make such use of it as will 
bring into cultivation the lands not adjacent to the strenms, thereby proteeting the settlers upon both elasses of lands, and at the same time not only encourige home building but enable the Gorermment to dispose of more of its lands, and to enhance its rerenues proportionately.

It often happens that an owner of land in arid districts does not want to farm them, but merely wants a home where he may raise stock or engage in other pursuits, requiring only suffieient water supply to meet the natural wants incident thereto, and for which no artificial diversion or application of the stream may become necessary. It will not, therefore, necessarily be presumed that such settler intends to irrigate his lands or that he will ever demand the water for such purposes, for which reason Congress eridently intended by the language used in the act of 1877 that if desired for such pmrposes some manifestation thereof, by diversion or other suflicient notice, slould be given, and if not desired for the reclamation of his lands that the owner should not be permitted to complain if another shall so apply it.

But, as regards the requirements for domestic use, the settlement, or other steps taken looking toward the procurement of title thereto, gives ample notice that the water for all necessary domestic uses is and will continue to be demanded as appurtenant to the land entered-as much so as wonld al diversion of the water for such purposes; while if intended to be appropriated for mining, irrigation, or power purposes, some affirmative action in that direction is essential, and it is but reasonable to require a clear manifestation of an intent or notice thereof. This requirement is vital to the initiation of sueh a right, for the same reason that some notice is exacted for the entry of the land itself. Congress could reasonably presume that if an appropriation were desired for the purpose mentioned in the act, some steps would be taken manifesting such intent, and that if the owner is not the first to move in that direetion the person making an application thereof to a beneficial use within a reasonable tine ought to be rewarded for his diligenee, and he is entitled to have his rights in that respect reeognized and protected. For this reason the settler who has acquired title to the land through which any stream may flow took it subject to the rights of the person who has or who may subsequently make the first use of such stream for the purpose enumerated in the act, excepting only as to the natural wants and needs of such settler.

Our attention is called to references in our statute to riparian rights ( $B$. and C. Comp., 4994, 5000), which, it is argued, recognizes the doetrine of riparian rights as being in force in this State, regardless of the net of Congress nuder consideration. It conld with equal strength be maintained that see. $5002 \mathrm{ib}$. which provides that "all controversies respecting rights to water under this act shall be determined by the dates of the appropriations as respectively made by the parties," constitutes a declaration to the effect that the doctrine of prior appropriation shall prevail.

The statute does not attempt to define riparian rights nor to determine the extent or effect of the doctrine as applied to irrigation. It has reference only to such rights as such riparian owner as the proprietor may have, whatever they may be; and the question as to what such rights are, and since 1877 have been, is the one under consideration here. Owners of land adjacent to bodies of water have riparian rights other than those presented in this controversy: See Morton $v$. O. S. L. Ry. Co., 48 Or., 444 ; Coquille Mill and M. Co. v. Jolmson (Or.), 98 Pac., 154. As hereinbefore held. the act of 1877 only affects ripa-rian rights to lands the title to which has been acquired since that date. and then only in so far as a elaim to the use of water ma be asserted, as riparian owner for the purposes in the act enumerated. And in this connection it will be observed that sec. 5000, B. and C. Comp., protects the owner contiguous to 
the stream. as against those claiming under the act of which that section is a part, in his right to the flow of the stream to the extent required for household, domestic, and other uses incident thereto, with sufficient quantity for irrigation purposes to the extent then actually needed and in use. An exception to that extent is accordingly made in favor of the landowner, as against, and only to the extent of, such rights as may be asserted under the act.

Our attention is called to Sturr $v$. Beck, 133 U. S., 541. That was a controversy between a riparian owner and a subsequent but prior appropriator, and was submitted on an agreed statement of facts. Based upon these stipulations, the trial court made findings, among which was that the defendant's first settlement upon his land through which the stream flowed was in March, 1877 , and that he made a homestead filing thereon on the 25th of the same month. Those findings were conclusive upon the appellate conrt. The date alluded to does not disclose whether the settlement was prior or subsequent to Ifarch 3,1577 , the date of the desert-land act.

Owing, therefore, to the uncertainty as to the date of settlement this decision can not be held in point. And the further fact that no reference appears as to the exact date clearly indicates that either the settlement was made before that date, or that the question did not occur to the litigants and was accordingly not urged before the court, nor considered by it. But whaterer view may be taken in this respect, its bearing on the question at hand is practically disregarded, if not overruled, by that conrt in its declaration on the subject through Mr. Justice Brewer, in United States $r$. Rio Grande Irr. Co., above quoted, as well as in the general reference to this act by the same court in an opinion by Mr. Justice White in Gutierres $v$. Albuquerque Land Co., 1SS U. S., 545. To the extent, therefore, that Sturr $v$. Beck may be deemed a precedent, as regards riparian rights, its weiglit is materially lessened, if indeed the rule as there and previously enunciated on the suluject is not overruled by that court in the recent case of Kausas $v$. Colorado, 206 U. S., 40. In Sturr $v$. Beck it was, in effect, held that the plaintiff could make no appropriation as against Beck. who was a riparian proprietor and who was entitled to the undiminished flow of the stream. This claim as to the law was asserted and the same application thereof insisted upon in Kansas $v$. Colorado, in which the citizens of Fansas insisted that large quantities of water were heing diverted from the Arkansas River ly the inhabitants of Colorado, a large mmber of whom were claiming as prior applopriators and diverting the water to nonriparian lands, as against Kansas, a riparian proprietor. In Kansas the modified doctrine of riparian rights prevailed, while in Colorado prior appropriation was and is recognized as the governing doctrine. The conrt refused injunctive relief and dismissed the bill, stating in substance that if the riparian doctrine should previl in Lausas as against Colorndo and against the nonriparian users whose rights were involved therein, Oklithoma and its citizens lower on the Arkansas River might invoke the same rule in opposition to both the citizens of Kansas and Colorado, to their great injury, which doctrine, it is observed, would be ruinous in its effect. The court, in dismissing the bill, indicated that no injunction would lie until a more substantial injury could be shown, and at the same time found that the interference by a large number of the appropriators above in the State of Colorado materially depleted the flow to the riparian lands of the plaintiff. This opinion was written by Mr. Justice Brewer, who was not a member of the court when the case of Sturr $v$. Beck was argued and submitted, for which reason, although a member of the court when the opinion in the latter case was filed, he took no part in the decision. The opinion in the Kansas-Colorado case not only brushes aside the rule claimed to have been announced in Stur $r$. Beck, regarding riparian rights, but discloses what, in the opinion of the writer, is a strong and 
commendable tendency on the part of that great conrt to recognize that the rigid rules of common law, as interpreted and sought to be applied by those insisting upon the "undiminished flow" theory, are inapplicable to the many new and intricate questions necessarily arising under our form of government and through the arid and semiarid sections. For a specified stitement of the facts in this case, disclosing many of the defendants to have been using the water on nonriparian lands, see the first opinion, which was on demurer: Kansas $v$. Colorado, 185 U. S., 125.

\section{WATER POWERS ON NAVIGABLE STREAMS.}

Under existing laws and interpretations thereof the Federal Government is prevented from exercising full sovereign control over any waters except those in the Territories. It will therefore be of interest to review the character of national legislation respecting the development of water powers.

It is clear that on navigable streams the unregulated development of water power would interfere with navigation. Therefore, while the authority of the Federal Government does not extend to the regulation of water-power development per se, it must intervene to the extent necessary to preserve or to facilitate navigation. Power development on these streams must therefore be subject to the dietates of the Federal Government in so far as may be necessary to accomplish this purpose. The present national law relative to the development of water powers on navigable streams reads as follows (Rev. Stat., chap. 3508, vol. 34, p. 386) :

An act to regulate the construction of dams across navigable waters.

Be it enaeted by the Scnate and Touse of Representatives of the Unitcd states of Ameriea in Congress assembled, That when, hereatter, authority is granted by Congress to any persons to construct and maintain a dam for water power or other purposes across any of the navigable waters of the United States, such dams [sie] shall not be built or commenced nntil the plans and specifications for its construction, together with such drawings of the proposed construction and such map of the proposed location as may be required for a full understanding of the subject, have been submitted to the Secretary of War and Chief of Eugineers for their approval, or until they shall have ajproved such plans and specifications and the location of such dam and accessory works; and when the plans for any dam to be constructed undel the provisions of this act have been approved by the Chief of Engineers and by the Secretary of War it shall not be lawful to deviate from such plans either before or after completion of the structure unless the modification of such plans has previously been submitted to and received the approval of the Chief of Engineers and of the Secretary of War: Provided, That in approving said plans and location such conditions and stipulations may be imposed as the Chief of Engineers and the Secretary of War may deem necessary to protect the present and future interests of the United States, which may inclnde the condition that such persons shall construct, maintain, and operate, without expense to the United States, in connection with said dam and appurtenant works, a lock or locks, booms, sluices, or any other strnctures which the Secretary of War and the Chief of Fingineers at any time may deem necessary in the interest of navigation, in accordance 
with such plans as they may approve, and also that whenever Congress shall anthorize the construction of a lock, or other structures for narigation purposes, in connection with such dam, the person owning such dam shall convey to the Cnited States, free of cost, title to such land as may be required for such constructions and approaches, and shall grant to the United States a free use of water power for building and operating such constructions.

Src. 2. That the right is hereby reserved to the United States to construct, nuintain, and operate, in connection with any dam built under the provisions of this act, a suitable lock or locks, or any other structures for navigation purposes, and at all times to control the said dam and the level of the pool caused by said dam to such an extent as may be necessary to provide proper facilities for navigation.

SEc. 3. That the person, company, or corporation building, maintaining, or operating any dam and appurtenant works, under the provisions of this act, shall be liable for any damage that may be inflicted thereby vpon private property, either by overflow or otherwise. The persons owning or operating any such dam shall maintain, at their own expense, such lights and other signals thereon and such fishways as the Secretary of Commerce and Labor shall lrescribe.

SEc. 4. That all rights acquired under this act shall cease and be determined if the person, company, or corporation acquiring such rights shall, at any time, fail to comply with any of the provisions and requirements of the act, or with any of the stipulations and conditions that may be prescribed as aforesaid by the Chief of Engincers and the Secretary of War.

SEc. 5. That any persons who shall fail or refuse to comply with the lawful order of the Secretary of War and the Chief of Engineers, made in accordance with the provisions of this act, shall be deened guilty of a violation of this act, and any persons who shall be guilty of a violation of this act shall be deemed guilty of a misdemeanor, and on conviction thereof shall be punished by a fine not exceeding five thousand dollars, and every month such person shall remain in default shall be deemed a new offense and subject such persons to additional penalties therefor: and in addition to the penalties above described the secretary of War and the Chief of Engineers may, upon refusal of the persons owning or controlling any such dam and accessory works to comply with any lawful order issued by the Secretary of War or Chief of Engineers in regard thereto, canse the removal of such dam and accessory works as an obstruction to navigation at the expense of the persons owning or controlling such dam, and suit for such expense may be brought in the name of the United States against such persons, and recovery had for such expense in any court of competent jurisdiction; and the remoral of any structures erected or maintained in violation of the provisions of this act or the orfler or direction of the secretary of War or Chief of Engineers made in pursunce thereof may be enforced by injunction, mandamus, or other summary process, upon application to the circuit court in the district in which such structure may, in whole or in part, exist, and proper proceedings to this end may be instituted under the direction of the Attorney-General of the United States at the request of the Chief of Engineers or the Secretary of War: and in case of any litigation arising from any obstruction or alleged obstruction to navization created by the construction of any dam under this act, the cause or question arising may be tried before the circuit court of the United States in any district in which any portion of said obstruction or dam tonches.

Skc. 6. That whenever Congress shall hereafter by law authorize the construction of any dam across any of the navigable waters of the United States, and no time for the commencement and completion of such dam is named in 
said aet, the anthority thereby granted shall cease and be mull and void unless the actual construction of the dam authorized in such act be commenced within one year and completed within three years from the date of the passage of such act.

SEc. 7. That the right to alter, amend, or repeal this act is hereby expressly reserved as to any and all dams which may be constructed in aceordance with the provisions of this act. and the United States shall incm 110 liability for the alteration. amendment, or repeal thereof to the owner or owners or any other persons interested in any dam which shall have been eonstructed in accordance with its provisions.

SEc. 8. That the word "persons" as used in this act shall be construed to import both the singular and the plural, as the case demands, and shall inchide corporations, companies. and associations.

Approved, June 21, 1906.

The above-quoted act vests no anthority in the Federal Government to regulate corporate features of any development, nor the distribution of power, nor the rates to be charged therefor, nor any other matter of public interest except that of navigation. In pursuance of the law, seventy-erght special acts have been passed by Congress anthorizing the construction of dams across navigable waters. Whether or not the authority indicated in the act confers upon the Federal Government the right to do more than to preserve the navigability of an inland waterway is a question that is in dispute at the present time. President Roosevelt vetoed two bills granting franchise for the construction of dams under this act, declaring that he would withhold his approval from all bills of this kind unless they provided that-

There shonld be a license fee or charge, which. thongh small or nominal at the ontset, ean in the future be adjusted so as to seeure a control in the interest of the public.

The following excerpt from a report ${ }^{a}$ presented by Hon. Knute Nelson, United States Senator from Minnesota, on behalf of the Senate Committee on Conmerce, contains an argument against such a doctrine:

The President, in a commmication addressed to the chairman of the Senate Committee on Commerce, dated March 18 last, as well als in his veto messigge of April 17, relating to the bill (II. R. 15444) to extend the time for the construction of a dam across liainy River, has declared it to be his poliey not to alprove of any bill permitting the construction of a dam by private parties across a navigable stream, although due provision is made for the conservation of the stream for the purposes of naviration, muless the hill provides for the payment of a royalty or compensation to the Inited States for the use of the water of the stream for purposes other than navigation.

This is a new departure from the policy heretofore pursued in respect to legislation anthorizing the construction of such dams, and in view of this fact it becomes important to inquire whether the Government of the United states has the right to require compensation for the use of water in such streams for murposes other than navigation. 
The common-law doctrine of Eugland that a stream is not deemed to be a navigable watereourse unless the tide ebbs and flows in it is not the law in this country. The question whether a watereourse is a navigable stream is one of fact. If it is capable of being used for the purposes of trade and commerce in any mode, even for floating lafts of $\operatorname{logs}$ and timber, it is deemed to be a mavigable stream.

('The Montello, 20 Wall., 430.)

(St. Anthony Water Power Company v. St. Paul Water Commissioners, 169 C. S.. 349.)

The title to the water of a narigable stream within the borders of a state is not in the Federal Government, but in the State; and title to the banks and bed of the stream, after the Federal Gorernment has parted with its riparian lands, is either in the State or in the riparian owner, or both, according to the laws of the respective States. These principles have been laid down and alpplied by the Supreme Court of the United States in the following among other cases, and is the settled law of the land, to wit: Martin $v$. Waddell (16 Pet., 367) ; Pollard $v$. Hagan (3 How., 212) ; Goodtitle $v$. Kibbe (9 How., 471 ) ; Barner $v$. Keokuk (94 U. S., 324) ; St. Louis $v$. Myers (113 U. S., 566); Packer $v$. Bird (137 U. S., 661) : Hadrin $v$. Jordan (140 U. S., 371) ; Kaukauna Water Power Company $v$. Green Bay and Mississippi Canal Company (142 L. S., 254) ; Shively $v$. Bowlby (152 U. S., 1) ; Water Power Company $v$. Water Commissioners (16S U. S., 349) ; Kean v. Calumet Canal Company (190 U. S., 45.2); United States $x$. The Chandler Dunbar Water Power Company (U. S. Supreme Court, April 20, 1908).

The nse of water in such a stream is a matter of state regulation and state control. In many of the states the common-law rule, as defined in the following language of Chancellor Kent, prevails, to wit:

" Every proprietor of lands on the banks of a river has naturally an equal right to the use of the water which flows in the stream adjacent to his lands, as it was wont to run (eurrere solebat), without diminution or alteration. No proprietor has a right to use the water to the prejudice of other proprietors above or below him unless he has a prior right to dirert it, or a title to some exclusive enjoyment. He has no property in the water itself, but a simple usufruct while it passes along. Aqua currit et debet currere ut currere solebat is the language of the law. Though he may use the water while it runs over his land as an incident to the land, he ean not unreasonably detain it or give it another direetion, and he must return it to its ordinary ehannel when it leares his estate."

In the mining and arid States the rule of prior appropriation for mining and irrigation purposes prevails, and this rule of the States has been recognized by federal statutes (Rer. Stat., sees. 2339-2340). In some of the states there is a mixed application, as in California, of the common-law rule and the rule of prior appropriation.

But whatever rule may prevail in any state as to the use of the water in a stream, it is always subject to the following limitations, laid down by the Supreme Court in the case of the United States $v$. Rio Grande Dam and Irrigation Compans (174 U. S., 690) :

"Although this power of changing the common-law rule as to streams within its dominion undoubtedly belongs to each State, yet two linitations must be recognized: First, that in the absence of speeific authority from Congress a State ean not by its legislation destroy the right of the United States, as the owner of lands bordering on a stream, to the continued flow of its water; so far at least as may be neessary for the beneficial uses of the goverument property. Second, that it is limited by the superior power of the General Government to 
secure the uninterrupted navigability of all navigable streams within the limits of the United States. In other words, the jurisdiction of the General Government over interstate commerce and its natural highways rests in that Government the right to take all needed measures to preserve the navigability of the navigable watercourses of the country even against any state action."

Where the Federal Government is not interested as the owner of riparian lands the only interest it has in the water of a stream is as to its use for purposes of navigation, and it can lay no claim to the use of the water for any other purpose, not even for irrigation. (Kansas $v$. Colorado, 206 U. S., 46.)

In this case the United States appeared as intervener, but inasmuch as it founded its claim not on the question of navigation but on the question of irrigation, the court held that it had no ground for intervention and dismissed its petition. In reference to this subject the court says:

"It follows from this that if in the present case the National Government was asserting, as a gainst either Kansas or Colorado, that the appropriation for the purpose of irrigation of the waters of the Arkansas was affecting the navigability of the stream, it would become our duty to determine the truth of the charge. But the Goverument makes no sucl contention. On the contrary, it distinctly asserts that the Arkansas River is not now and never was practically navigable beyond Fort Gibson, in the Indian Territory, and nowhere claims that any appropriation of the waters by Kansas or Colorado affects its navigability.

"It rested its petition of intervention upon its alleged duty of legislating for" the reclamation of arid lands. ***

"Turning to the enumeration of the powers granted to Congress by the eighth section of the first article of the Constitution, it is enough to say that no one of them by any implication refers to the reclamation of arid lands. * * *

"While arid lands are to be found mainly if not only in the Western and newer States, yet the powers of the National Government within the limits of those States are the same (no greater and no less) than those within the limits of the original thirteen, and it would be strange if, in the absence of a definite grant of power, the National Govermment conld enter the territory of the states along the Atlantic and legislate in respect to improving, by irrigation or otherwise, the lands within their borders. Nor do we understand that hitherto Congress has acted in disregird to this limitation."

It was the doctrine at common law that a grant of land npon the borders of a navigable stream carried the grant only to high-water mark, while a grant of land bordering upon a nonnavigable stream carried the ownership to the center or thread of the stream, subject to the public easement.

In the case of Hardin $v$. Jordan (140 C. s., 38t), the supreme Court states:

"The United States have not repealed the common law as to the interpretation of their own grants, nor explained what interpretation or limitation should be given to or imposed upon the terms of the ordinary conreyances which they use except in a few special instances; but these are left to the principles of law and rules adopted by each local government where the land may lie. We have adopted the common law, and must therefore apply its principles to the interpretation of their grant."

Further on the conrt states the same principle in this form:

"In our judgment the grants of the Government for lands bounded on streams and other waters without any reserration or limitation of terms are to be construed as to their effect according to the laws of the State in which the lands lie."

The rule of riparian ownership as to grants of land borderiug on a navigable stream is diverse in the rarious'states. Some states hold that the grant 
extends only to high-water mark; other States hold that it extends to low-water mark, while another class of States-and perhaps the most numerous-hold that the grant extends to the middle of the stream, subject to the public easement in the water of the stream. But whaterer may be the law in this respect as to the effect of the grant, it only relates to the proprietorship in the banks and bed of the stream and not to the ownership of the water in the stream.

In those States which hold that the title of the riparian owner only extends to the high or low water mark the title to the bed of the stream is deemed to be in the State, and whether the title to the bed of the stream is in the riparian owner or in the State, in either case the general title to the water of the stream is deemed to be in the State, but it holds it not absolutely but in trust for all lawful public uses. The State's interest in such a stream is akin to that of a riparian owner, thongh more comprehensive and general in its nature, and does not exist in hostility to or in diminution of the rights of the riparian owner.

(Rossmiller $v$. State, 114 Wis.. 169.)

( Peoples Ice Co. $v$. Darenport, 149 Mass., 322.)

(Brown v. Cumningham, S2 Iowa, 512.)

(Braston $v$. Rockport Ice Co., 77 Maine, 100.)

(Martin et al. $v$. Waddell, 16 Peters, 367.)

From the foregoing it will appear that there are three different parties who are interested in the waters of a navigable stream-(1) the United States; (2) the State in which the stream is located; (3) the riparian owner. The interest of the United States is derived from and rests upon that paragraph of the Constitution which gives Congress the power to regulate interstate commerce, and this power only extends to the extent of conserving the navigability of the stream. Beyond that the Federal Governmeut has no interest or property in the stream.

The interest of the State in the stream is derived from its sovereignty and it holds its property in the stream in trust for all public uses but in subrogation to the rights of the Federal Gorernment as to navigation and of the riparian owner. The right to the use of the waters of a stream for any lawful purpose, outside of the right of navigation, belongs wholly to the State and the riparian owner.

(Martin et al. 1. Waddell, 16 Peters, 367.)

Chief Justice Shaw, in the case of Elliott $v$. Fitchburg Railroad Company (10 Cushing, 191). describes the rights of the riparian owner in the use of water in a stream in the following language, which states the enlarged and modified common-law doctrine:

"Tlie right to flowing water is now well settled to be a right incident to mroperty in the land; it is a right publici juris, of such a character that, while it is common and equal to all through whose land it runs and wo one can obstruct or divert it. ret, as one of the beneficial gifts of Providence, each proprietor has a right to a just and reasonable use of it as it passes through his land; and, so long as it is not wholly obstructed or diverted or no larger alppropriation of the water ruming through it is made than a just and reasonable use, it can not be said to be wrongful or injurious to a proprietor lower down. What is such a just and reasonable use may often be a difficult question, depending upon rarious eircumstances. To take a quantity of water from a large running stream for agricultural or manufacturing purposes would cause no sensible or practicable diminution of the benefit, to the prejudice of a lower proprietor; whereas, taking the same quantity from a small ruming brook passing through many farms would be of great and manifest injury to those below, who need it for domestic supply or watering eattle; and therefore it 
would be an unreasonable use of the water, and an action would lie in the latter' case and not in the former. It is therefore to a considerable extent a question of degree; still the rule is the same, that each proprietor has a right to a reasonable use of it, for his own benefit, for domestic use, and for manufacturing and agricultural purposes.

"That a portion of the water of a stream may be used for the purpose of irrigating land we think is well established as one of the riglits of the proprietors of the soil along or through which it passes. Yet a proprietor ean not, under color of that right or for the acturl purpose of irrigating his own land, wholly abstract or divert the watercourse or take such an mineasonable quantity of water or make such unreasonable use of it as to deprive other proprietors of the substantial benefits which they might derive from it if not diverted or used unreasonably. ***

"This rule, that no riparian proprietor can wholly abstract or divert a watercourse, by which it would cease to be a ruming stremu, or nse it unreasonably in its passage and thereby deprive a lower proprietor of a quality of his property, deemed in law ineidental and beneficial, necessarily flows from the principle that the right to the reasonable and beneficial use of a running stream is common to all the riparian proprietors. and so eacll is hound to use lis common right as not essentially to prevent or interfere with an equally beneficial enjoyment of the common right by all the proprietors. ****

"The right to the use of flowing water is pullici juris, and common to all the riparian proprietors; it is not an absolute and exclusire right to all the water flowing past their land, so that any obstruction would give a cause of action: but it is a right to the flow and enjoyment of the witer. subject to a similar right in all the proprietors to the reasonable enjorment of the same gift of Providence. It is therefore only for an abstraction and deprivation of this common benefit or for an unreasonable and unathorized use of it thit an action will lie."

The doctrine of prior appropriation, already referred to, is thus described by Justice Field in the ease of Jennison $r$. Kirk (9S U. S., 45i3). After describing the system of discovery and appropriation and development of mining elaims, he adds the following:

"But the mines could not be worked without water. Withont water the gold would remain forever buried in the earth or rock. To earry water to mining localities when they were not on the bank of a stream or lake beeame therefore an important and necessary business in carrying on mining. Here, also, the first appropriator of water to be conveyed to such locility for mining or other beneficial purposes was recognized as having, to the extent of actual use. the better right. The doetrine of the common lair respecting the right of riparian owners was not considered as applicable, or only in a rery limited degree, to the conditions of miners in the momtains. The waters of rivers and lakes were, consequently, earried great distances in ditehes and flumes, construeted with rast labor and enormous expenditures of moner, along the sides of mountains and through canyons and ravines, to supply communitios engaged in mining as well as for agriculturists and ordinary consumption. Numerous regulations were adopted, or assumed to exist from their obvions justness, for the security of these ditehes and flumes, and for the protection of rights to water, not only between different appropriators, but between them and the holders of mining claims. These regulations and custons were appealed to in controversies in the state courts, and received their sanction; and properties to the value of many millions rested upon them. For eighteen rears, from 1848 to 1866 , the regnlations and customs of miners, als enforced and molded by the conrts and sanctioned by the legislation of the state, consti- 
tuted the law governing property in mines and in water on the public mineral lands."

These water rights, by prior appropriation, as described by Justice Field, were recognized and confirmed by congressional legislation in 1866 and in 1870 . Those acts are now sections 2339 and 2340 of the Revised Statutes. Justice Field further adds:

"It will thus be seen that the federal statutes merely gave a formal sanction to the rules already established. Those rules had been built up iu reliance on the tacit acquiescence of the United States, the true owner of the lands and waters on which appropriations were made, and these statutes acquiesced therein expressly, 'a voluntary recognition of the preexisting right rather than the establishment of a new one." "

In the case of Broder $v$. Natoma Water Company (101 U. S., 274) the Supseme Court, in referring to the contention that these statutes established a new right, uses the following language:

"We are of the opinion that it is the established doctrine of this court that rights of miners who had taken possession of mines and worked and developed them, and the rights of persons who had constructed canals and ditches to be used in mining operations and for purposes of agricultural irrigation, in the region where such artificial use of the water was an absolute necessity, are rights which the Government had, by its conduct, recognized and encouraged and was bound to protect before the passage of the act of 1866 , and that the section of the act which we have quoted was rather a roluntary recognition of a preexisting right of possession, constituting a valid claim to its continued use. than the establishment of a new one."

These decisions of Judge Shaw, of Massachusetts, and of Justice Field, of the Supreme Court, describe fully the rights of the riparian owners to the use of the water both under the doctrine of the common law and under the so-called doctrine of prior appropriation, and the case of Rossmiller $v$. The State (114 Wis., 169), and the cases therein referred to, as well as the case of Martin et al. $v$. Waddell (16 Peters, 367), show the interest and property of a State in the waters of a stream.

From the foregoing statement and citation of authorities it is evident that the only use of the waters of a stream in which the United States has.any property is its use for purposes of narigation. In the use of the stream for any other purpose the Federal Government has no property, and hence has nothing to sell or to exact compensation for.

The plan proposed by the President wonld deprive the States and the riparian owners of their rights in the use of the water of a navigable stream now rested in them by law, and would concentrate the entire disposal and control in the Federal Government, a power which neither the States nor the riparian owners can, with justice or safety, for' a moment concede. But, assuming for the sake of the argument that the Federal Government can lay a tribute in such cases as is proposed by the President, it can not be under the interstate-commerce clause of the Constitution, but must be under section 8 of article 1 , which reads as follows:

"SEc. 8. The Congress slall have power to lay and collect taxes, duties, imposts, and excises, to pay the debts and provide for the common defense and general welfare of the United States: but all duties, imposts, and excises shall be uniform throughout the United States."

such a tribute must be either a direct tax or in the nature of an impost or excise tax. If a direct tax, it can not be levied directly by the Federal Government. but must be apportioned among the States, learing each state to make the collectiou; and if an impost or excise tax, then it must be levied by the rule 
of uniformity upon every dam and water power in the United states not constructed directly or indirectly by the Federal Govermment. In other words, there must be al general excise law on the subject. 'The power of the Federal Government over the navigable streams of the country is no greater in the socalled Western or public-land States than in the New England States. If a tribnte can be levied on a dam and water power in Minnesota or Colorado, it can be levied on a dam and water power in Maine or Massichusetts, for the power of the Federal Government over navigable streams is the same in the one case as in the other. In the case of Pollock 1 . Farmers Loan and Trust Company (157 U. S., 55T) the conrt states:

"Thus in the matter of taxition the Constitution recognizes the two great classes of direct and indirect taxes, and lays down two rules by which their imposition must be governed, namely, the rule of apportionment as to direct taxes and the rule of uniformity as to duties, imposts, and excises."

In the case of Thomas $v$. United States (192 U. S., 363), Chief Justice Fuller says:

"And these two classes, taxes so called, and 'duties, imposts, and excises,' apparently embrace all forms of taxation contemplated by the Constitution. As was observed in Pollock v. Falmers Loan and Trust Company (15T U. S., 429, 557), "Althounh there have been from time to time intimations that there might be some tax which was not a direct tax nor included under the words "dnties, imposts, and excises," such a tax for more than one hundred years of national existence has as yet remained undiscovered, notwithstanding the stress of particular circumstances has invited thorongh investigation into sonrees of revenue.' * * *

"There is no occasion to attempt to confine the words duties, imposts, and excises to the limits of precise definition. We think that they were used comprehensively to cover eustoms and excise duties imposed on importation, consmmption, manufacture, and sale of certain commodities, privileges, particular business transictions, rocations, occupations, and the like."

An act anthorizing the constritction of a dam is, so far as the United States is concerned, a mere revocable license or privilege, and if a tax can be imposed on such a privilege it must be general and uniform throughout the United States. It must apply to all dams and water powers on navigable streans throughout the entire comntry.

Nearly all navigable streams in their upper and more remote courses are not, as a matter of fact, navigable. and in such reaches of the river dams can be erected and water powers crented under state authority and state license, and so long as such dams and water powers do not materially injure or diminish the navigability of the stream in its navigable portions the Federal Government has no ground for interference. It has been customary. however, in many of such cases to apply to Congress for a federal license. and the granting of it, while not necessary, serves a twofold purpose, first, that it anthorizes the Federal Govermment, through the War Department, to control and direct the construction of the dam, and, second, that it recognizes the fact, which might otherwise require proof, that the dam will not affect the navigability of the stream in its navigable portions.

(Kansas v. Colorado, 206 U. S.. 46.)

(United States $v$. Rio (irande Company, 174 U. S., 690.)

And in such cases it is of as much advantage to the rnited states as to the grantee of the license to have congressional action and recognition. but in such cases the Fefleral Government has nothing to sell. and, therefore, has no moral or legal gromnd to demand compensition in any form. 
An adverse comment on the above report, made as a private memorandum on May 11, 1908, by Morris Bien, supervising engineer in charge of land and legal matters, United States Reclamation Service, is presented below:

MAY 11, 1908.

\section{Memorendum upon rewort of Committee on Commere of Scnate to accompany II. R. 1.70\%, sixticth Congress, first session, senate Report 585.}

The report discusses the power of Congress to authorize charges for the use of waters of narigable streams for power and other purposes in comnection with dams atuthorized to be constructed across such streams. A number of de(isions are cited tending to show that the ownership of the waters of narigable streams is in the states. In many of the deeisions cited the particular point of ownership is not nacessang to the decision of the ease and the expressions quoted are from the general discossion of the subject.

A careful stumy of the cases will lead to the conclusion that the general principle of ownership lyy the states of the waters of nal viguble streams has not been decided, nor cin it be exjereded that such a lminciple will be adopted by the courts beamse it is manifestly contrary to the fundamental idea of the Constitution thal congless shall have the power "to regulate commerce with foreign nations. and among the sereral states, and with the Indian tribes."

In the case of Gimm r. Philadelphia (:3 Wall, $713-724)$ the United States supreme Court held as follows:

"Commerce inchdes nalvialion. The fower to regulate commerce comprehends the control for lliat pmpose. and to the extent necessary, of all the navigable waters of the Inited States which are accessible from a State other than those in which they lie. For this purpose they ale the mblit property of the nation, and subject to all the requisite legislation by Congress."

In the calse of the United States r. The Rio Giande Dam and Irrigation Comlamy (174 U. S., (bog), there was involved the light of the company to operate muler a srant of right of way approved hy the secretary of the Interior under the general right-of-way act of Malcele 3, 1s.1. It was claimed that as the probosed reservoir Would imloumd practically all the waters of the Rio Grande the effect upon navigation was injurious and the company should be prohibited from utilizing the grant rinimed under the act of Congress.

The supreme comrt, after discussing sereral ats of Congress relating to the use of waters upon lands in the West, continnes als follows:

"To hold that Congress by these acts meant to confer mon any State the right to apnopriate all the waters of the trilutary streams which unite into a nalvigable waterourse, and so destroy the narigability of that watercourse in derogation of the interests of all the people of the Unitel States. is a construction which can not be tolerated. It ignores the spirit of the legishation and carries the statute to the rerge of the letter and far beyond what under the circumstances of the case must be heli to have been the intent of Congress." (I. 706.$)$

Proceeding then to disenss the act of September 19, 1590, prohibiting the obstruction of the marigable capacity of any waters orer which the United States bas jurisdiction, the court holds that-

"Any obstruction to the navigable capacity, and anything, wherever done or howerer done. within the limits of the jurisdiction of the Tnited States which tends to destroy the navigalle capacity of one of the navigalle waters of the Tnited states, is within the terms of the prohibition. Evidently Congress, per- 
ceiving that the time had come when the growing inlorests of commerce reduired that the navigable waters of the United states should be subjereded to the direct control of the National Govermment. and that nothing should be done by the State tending to destroy that navigability without the explieit assent of the National Government, enacted the statute in question. And it would be to improperly ignore the scope of this language to limit it to acts done within the very limits of navigation of a navigable stream." (l'. 708.)

This ease involved the waters of the rio dimule within the limits of the Territory of New Mexico and it might therefore be doubted that it was intented to have a general effect and apllicable to water's of navigable streans within the limits of States.

This is, howerer, not the ease, because the decision rests upon the powro of Congress over interstate commerce and is not based mpon any principle which is applicable solely to the 'lerritories.

This is made more evident by the illustration which the court gives in regaril to the waters of the Hudson River, calling attention to the fact that it is a navigable stream, at least from Allany southward, and disenssing the rights of the State of New York to appropriate the waters of its tributaries, stating that while the State might anthorize the diversion of the waters of the tributaries of the Hudson and the United States may not question such appropriation unless the navigability of the Hudson be disturbed, yet if the State of New York should, even at a place above the limits of navigalinity, so diminish the volume of the waters as to destroy its navigability the jurisiliction of the National Government undoubtedly would arise and it would become the right of the Attorney-General to institute procedings to restrain such apluropriation. (P. 709.)

While the word "navigation" is not in the Constitution the word "commerce" comprehends it. (Gibbons $x$. Ogden, 9 Wh., 1-222.) Accordingly the States can have no power to exereise ownership or control over the waters of navigable streams that will in any manner interfere with the regulation of commerce by Congress. In the ase of Glonester Ferry Company r. I'ennsylvania (114 U. S., 196-203) the Inited States Snpreme Conrt lield thint the power to regulate commerce "is the power to prescribe the rules by which it shall be governed; that is, the conditions upon which it shall be comflucten ; to determine when it shall be free and when subject to duties or other axuctions."

Congress has in many cases required payment for the use of the instrumentalities of commeree and navigation, Many instances may be cited, such as the charge of toll for vessels using canals, charges placed on immigrants, and the like. These are not taxes, but are in the nature of license cliarges.

The requirements of fees or clrarges of valious kinrls is insepalrably connected with the power to regulate and has been so held in numerous instances.

This question was fully discussed in the ITead Money Cases (112 U. S., 580 ). This case involved the constitutionality of the immigration act, requiring layment of a duty of 50 cents for every passenger brought into the country who was not a citizen of this comtry. The constitutionality of the act was uphed upon the ground that it was a proper form of regulation of commerce.

Objection was made to the act, among other things, that this duty of 50 cents per head was not a proper exercise of the taxing power conferred upon Congress by the Constitution. The court, however, held that this was not a tax, and said:

"We are clearly of the opinion that, in the exercise of its power to regulate immigration and in the very act of exercising that power. it was competent for" Congress to impose this contribution on the shipowner engaged in that husiness."

The matter reduces itself to the following propositions, which seem selfevident. Congress has the power to rexulate commerce between the states, 
which inclules navigation upon navigable waters: and the power to regulate the use of navigable waters includes the power to make appropriate charges for the use of all instrmmentalities connected therewitl.

A further comment on the same doctrine, by Charles Edward Wright, is as follows: ${ }^{a}$

In certain quarters it is denied that the United States has power to impose a charge in sueh a case. It is argued that the charge would be either a direct tax or in the nature of an impost or excise tax. If the former, it must be apportioned among the States rather than levied directly by the Federal Gorernment itself ; if the latter, it must be uniformly levied on every dam and water power in the entire comtry.

The latter objection, however, is not altogether sound. Uniformity, in the sense of the constitutional provision respecting taxation, means a geographical uniformity, the tax operating on all similar properties. That is, in every instance where the Federal Government approves the location and plans of a dam, thereby authorizing its construction, whether in a navigable waterway east, west, north. or south, the tax must be uniformly laid. But a water power dereloped on a nonnavigable stream, without let or license from the National Government, would stand in another category. Any rule of conformity would not necessarily involve the inclusion of such dams or water-power privileges; it would merely require the levy of such a tax upon every power privilege similarly authorized or confirmed by the Federal Govermment.

Recurring to the act of Congress establishing the California Débris Commission, already noticed in part, we find provisions for a "tax" which applies with no "geographical miformity" throughout the country, but is restricted in operation to only a part of the State of California.

Brietly, the lydraulic process in mining may not be employed about the tributaries of certain mavigable streams in that State without permit from the commission, the permit to be santed upon petition and hearing. The license, if granted by a majority of the board, embodies directions and specifications in detail as to the mamer in which operations may proceed; what restraining or imponnding works slatl be built and maintained, and where they shall be located; "and in general set forth such further requirements and safeguards as will protect the public interests and prevent injury to the said navigable rivers, and the lands adjacent thereto, with such further conditions and limitations as will observe all the provisions of this act in relation to the working thereof and the payment of taxes on the gross proeceds of the same. Provided, That all expense incurred in complying with said order shall be borne by the owner or owners of such mine or mines." (Act of March 1, 1893, sec. 13.) The "taxes on the gross proceeds" are imposed by the twenty-third section of the act, which provides that the operators of the mines affected by the act " shall pay a tax of three per centum on the gross proceeds" of the mine so worked, said "tax" to be ascertinined and paid in accordance with regulations to be adopted by the Secretary of the Treasury and to be paid into the Federal Treasury to the credit of the "débris fund," which shall be expended by said commission under the supervision of the Chief of Engineers and direction of the Secretary of War in the construction and maintenance of restraining works and settling reservoirs in aid of the purpose Congress had in mind in passing the act.

This act had been held to be constitutional, as alrealy noted. Yet in terms it provides for the collection of a "tax" which is neither "apportioned" among

a The scope of state and federal leglslation concerning the use of waters, by Charles Edward Wright, Assistant Attorney to the Secretary of the Interlor: Annals Am. Acad. lolit. and Social Sci., 1909, pp. 577-581. 
the States nor is levied by any rule of uniformity. Rather than a general excise law, it is one of special and circumscribed application. Still, the charge imposed is christened a "tax." If it were a tax, there can be little doubt of the unconstitutionality of the act. Wherein does such a "tax" differ from that to be charged upon the grant of special privileges for power purposes in a navigable stream? Both find their reason for existence in the conservation of narigation, although the miner's may be required to pay for privileges connected directly with nonnavigable intrastate tributaries, while the power producers operate directly in the navigable stream itself.

But the charge is not a "tax" in the constitutional sense; it is of the nature of a license-the according of a special right or privilege to do a thing, which, without permission, would be mulawul. It is leave and liberty enjoyed as a matter of indulgence at the will of the Federal Government. ***

The power to charge for a special privilege is not necessarily an exercise of the power to tax. It is lather the right to exact a quid pro quo. Public interests are bound to be jeopardized, even though certain advantages to a locality acerue from the establishment of the power plant. One has already been suggested-the operation of a lock; for the rery fact that gives the Federal Gorernment any measure of control-viz, the navigability of the stream-involves the conservation of navigation through artificial means. The charge imposed liquidates this that otherwise would be a burden in the nature of a tax upon the public. Aside from this, another potential element of cost to the public is involved-the possibility that the Government may be obliged to remove the obstruction caused by the building of the dam at its own cost. Ordinarily this has been guarded against by the exaction of a bond in a large penal sum, the burden of carrying which is an annual charge upon the owners of the franchise. What vital objection can there be to the adoption of a plan whereby the licensee, in lieu of annual tribute to a bonding company, pays such premiums into the Federal Treasury - a measure of insurance against the loss that might be occasioned were the franchise holder bankiupt and the needs of navigation were to require the removal of the dam? The fund created by the payment of these charges may be either deroted directly to the betterment of navigation, particularly in the removal of onstructions, or turned into the Treasury as a part of the general fund, indirectly serving the same purpose by relieving the taxpayer. If the Federal Government has the power to withhold approval, it has power to bestow approval upon such terms as it may deem necessary to impose in order to protect the present or future interests of the United States. If it has the power to exact a bond to protect the publie against loss when, in the interest of navigation, it becomes necessary to remore the obstruction, it has the power to create a fund for the same purpose. If the public in general contribute to that fund, their contributions are in the nature of a tax. If, however, the special beneficiaries of the granted permission contribute to establish such a fund, it is not a tax, but a license charge, the sole similarity being that both are a rendering to Cresar of the things that are Cresal's.

Moreover, it is entirely competent for Congress to insist that no privileges $a$ affecting navigable streams shall be granted to any corporation unless said corporation operates under a federal charter. The United States has authority to create a corporation as a means of carrying into effect any of its sovereign power's. (Meculloch v. Naryland, 4 Wheat., 316, 411.) Such a corporation. may be authorized to construct a dam and lock in aid of navigation, and the incidentally developed power may be disposed of by the creature as well as by

a That is, privileges other than the use of the stream for natural navigable purposes.C. E. W. 
the sorereign itself-under such terms and conditions as Congress sees fit to impose. This wonld bring every lower company using the narigable waters of the nation directly under the visitorial control of a federal commission-the Interstate Commeree Commission, for instance-with power to regulate charges and to prevent the formation of unlawful or monopolistic combinations. It is only natural that such companies should receive their corporate animation from the power which controls and regulates interstate commerce, because the ulterior purpose of their being, thus ereated, would be the production and transmission of power, in itself a feature of commerce which, in its development and utilization, will acknowledge no state bounds. In the ineorporation of such connanies. compled with the grant of these privileges in the waterways of the nation, the imposition of charges, the tribute that the creature pays to its ereator, will follow easily, logically, and lawfully.

\section{GOVERNMENT DAMS ON NAVIGABLE STREAMS.}

Another phase of the water-power situation on navigable streams appears at those points where, by reason of abrupt or excessive fall in the channel, it is necessary to canalize the river in order to make it possible or safe for navigation. Canalization involves the construction of a dam, and by such construction the United States is often the creator of a water-power site. It is probably true that the Government can not, by authority of the Constitution, construct water powers for commercial purposes, such powers as it is forced to construct in the canalization of a river being merely incidental to the purposes of navigation. But it has generally been conceded that, although the Federal Government does not own the corpus of the water, it does own the power that it creates, and it follows logically that it can and really does dispose of such power by lease. The practice, however, is not general, and the Government is by no means obtaining proper returns for the power that it has incidentally created, chiefly because many of the power sites are not yet in commercial demand. The reasons for this are numerous. At many of the dams shortage of water occurs during the summer senson, and at such times the primary power is therefore reduced. At other points the amount of power available is limited by the low head afforded by the dams, and it will not therefore be utilized until the commercial demand is increased. Another reason is that many of the government sites are in Infavorable localities. Again, their development may be checked by the low price of fuel power. But these factors will not always be predominant, and we may expect a far greater demand for the power developed at government dam sites than there has been in the past if the difficulty existing at so many places, namely, the lack of water during dry seasons, is overcome. The construction by the Federal Government of reservoirs in the uplands and the preservation of forests wonld accomplish this end. Such reservoirs would clearly benefit navigation and they would at the same time incidentally benefit the water power. It thus appears that under some conditions 
the Federal Government may have control over certain water power's on navigable streams by right of proprietorship.

According to a statement made by the Chief of Engineers, U. S. Army, to the National Conservation Commission in 1908, the power generated at government dams is sold to the amount of 3,243 horsepower, the revenue therefrom being $\$ 5.578 .97$. The power so used is located principally on Muskingum, Green, and Kentucky rivers in the Ohio Valley.

\section{WATER POWERS ON THE PUBLIC LANDS.}

Federal laws providing for the development of water powers on the public lands have so far consisted merely of clauses or phrases in certain land laws regarding rights of way. They provide for no regulation of water power, nor do they effectively prevent the diverse abuses that have grown up in connection with water-power operation and manipulation, except in the national forests, later to be discussed. The two principal laws relative to this matter are as follows:

\section{[26 Stat., $109 \%$.}

SEc. 1S. That the right of way through the public lands and reservations of the United States is hereby granted to any cumal or ditch company formed for the purpose of irrigation, and duly organized under the laws of any state or Territory, which shall have filed or may liereafter file with the secretary of the Interioi a copy of its articles of incorporation and due proofs of its organization under the sime, to the extent of the ground occupied by the water of the reservoir and of the canal and its laterals. and 50 feet on each side of the marginal limits thereof; also the right to take from the public lands adjacent to the line of the canal or ditch material, earth, ant stone necessary for the construction of such canal or ditch: Provided, That no such right of way shall be so locited as to interfere with the proper occupation by the Government of any such reservation, and all maps of location shall be subject to the approval of the department of the Government having jurisdiction of such reservation, and the privilege herein granted shall not be construed to interfere with the control of water for irrigition and other purposes under anthority of the respective States or Territories.

SEc. 19. That any canal or ditch comprany desiring to secure the benefits of this act shall, within twelve montls after the locition of 10 miles of its canal, if the same be upon surveyed lands, and if mpon msmreged lands within twelve months after the survey thereof by the United States, file with the register of the land office for the district where such land is located a map of its canal or ditch and reservoir; and upon the aplroral thereof by the Secretary of the Interior the same shall be noted njon the plats in said oflice, and thereafter all such lands over which such lights of way shall pass shill he disposed of subject to snch right of way. Whenerer any person or corporation, in the construction of any canal, ditch, or leservoir, injures or damages the possession of any settler on the public domain, the party committing such injury or damage shall be liable to the party injured for such injury or damage.

SEc. 20. That the provisions of this act shall apply to all callals, ditches, or reservoirs heretofore or hereafter constructed, whether constructed by corpori- 
tions, individuals, or association of individuals, on the filing of the certificate and maps herein provided for. If such ditch, canal, or reserroir has been or shall be constructed by an individnal or association of individuals, it shall be sufficient for such individual or association of individuals to file with the Secretary of the Interior and with the register of the laud office where said land is located a milp of the line of such canal, ditch, or reservoir, as in case of a corporation, with the name of the individnal owner or owners thereof, together with the articles of association, if any there be. Plats heretofore filed shall have the benefits of this act from the date of their filing, as though filed under it: Provided, That if ans section of said canal or ditch sliall not be completed within five rears after the location of said section the rights herein granted shall be forfeited as to any uncompleted section of said canal, ditch, or reservoir, to the extent that the same is not completed at the date of the forfeiture.

SEc. 21. That nothing in this act shall authorize such cana1 or ditch company to occupy such right of way except for the purpose of said canal or ditch, and then only so far as may be necessary for the construction, maintenance, and care of said canal or ditch.

General Land Office regulations relative to the administration of the above-quoted act contain the following statements: ${ }^{a}$

3. Control of water.-While these acts grant rights of way over the public lands necessary to the maintenance and use of ditches, canals, and reservoirs, the control of the flow and use of the water is, so far as this act is concerned, rested in the States or 'Territories, the jurisdiction of the Department of the Interior being limited to the approval of maps carrying the right of way over the public lands. If the right of way applied for under this act in any wise involves the appropriation of matural sources of water supply, the damming of rivers, or the use of lakes, the maps should be accompanied by proof that the plans and jurposes of the projectors lave been regularly submitted and approved in accordance with the local laws or customs governing the use of water in the state or 'Territory in which such right of way is located. No general rule can be adopted in regard to this matter. Each case must rest upon the showing filed.

4. Nature of grant.- The right granted is not in the natmre of a grant of lands, but is a base or qualified fee. 'The possession and right of use of the lands are given for the purposes contemplated by law, but a reversionary interest remains in the United states, to be conveyed by it to the person to whom the land may be patented, whose rights will be subject to those of the urantee of the right of way. All persons settling on a tract of public land, to jart of which right of way has attached for a canal, ditch, or reservoir, take the land subject to such right of way, and at the total area of the subdivision entered, there being no authority to make deduction in such cases. If a settler has a ralid claim to land existing at the date of the filing of the map of definite location, his right is superior, and he is entitled to such reasonable measure of damages for right of way as may be determined upon by agreement or in the courts, the question being one that does not fall within the jurisdiction of this department. Section 21 of the act of March 3, 1891, provides that the grant of a right of way for a canal, ditch, or reservoir does not necessarily carry with it a right to the use of land 50 feet on each side, but only such land may be used as is necessary for construction, maintenance, and care of the canal, ditch, or reservoir. The width is not specified.

"Regulations concerning right of way over public lands and reservations for canals, ditches, and reservoirs, and for use of right of way for various purposes; approved June 6, 1908, pp. 4, 5. 
The second right-of-way act is entitled "An act relating to rights of way through certain park reservations and other public lands," approved February 15, 1901 (Stat. L., vol. 31, p. 790), as follows:

Be it enacted by the Senate and House of Representatives of the United states of America in Congress assembled, That the Secretary of the Interior be. and hereby is, authorized and empowered, under general regulations to be fixed by him, to permit the use of rights of way through the public lands, forest and other reservations of the United States, and the rosemite, Sequoia, and General Grant national parks, California, for electrical plants, poles and lines for the generation and distribution of electrical power and for telephone and telegraph purposes and for canals, ditches, pipes and pipe lines, ffumes, tumels, or other water conduits, and for water plants, dams, and reservoirs used to promote irrigation or mining or quarying, or the manufacturing or cutting of timber or lumber, or the supplying of water for domestic, public, or any other beneficial uses to the extent of the gromd occupied by such canals, ditches, flumes, tunnels, reservoirs, or other water conduits or water plants or electrical or other works permitted hereunder and not to exceed fifty feet on ench side of the marginal limits thereof, or not to exceed fifty feet on each side of the center line of such pipes and pipe lines, electrical, telegraph, and telephone lines and poles, by any citizen, association, or corporation of the United States, where it is intended by such to exercise the use permitted heremder or any one or more of the purposes herein named: Provided. 'That such permits shall be allowed within or through any of said parks or any forest, military, Indian, or other reservation only upon the approval of the chief officer of the department under whose supervision such park or reservation falls, and npon a finding by him that the same is not incompatible with the public interest: Provided further, That all permits given hereunder for telegraph and telephone purposes shall be subject to the provision of title sixty-five of the Revised Statutes of the United States, and amendments thereto, regulating rights of way for telegraph companies over the public domain: And provided furthor, That any permission given by the Secretary of the Interior under the provisions of this act may be revoked by him or his sncessor in his discretion. and shat not be held to confer any right, or easement, or interest in, to, or orer any public land, reservation, or lark.

\section{FOREST SERVICE REGULATIONS.}

The only water-power regulation attempted by the Federal Government is that exercised by the United States Forest Service on the national forests. Authority for such regulations is based on several federal laws relating to forest reservations, viz:

\section{[Act of June 4, 1897 (30 Stat., 11).]}

All the public lands heretofore designated and reserved by the President of the United States under the provisions of the act approved March 3, 1891, the orders for which shall be and remain in full force and effect, unsuspended and unrevolied, and an public lands that may hereafter be set aside and reserved as public forest reserves under said act, shall be as far as practicable controlled and administered in accordance with the following movisions.

The Secretary of the Interior slall make provisions for the protection algainst destruction by fire and depredations npon the public forests and forest reserra- 
tions, which may have been sot aside or which may be hereafter set aside, mnder the act of March 3, 1891, and which may be continued; and he may make such rules and regulations, and establish such service as will insure the objects of such reservations, namely, to regulate their occupancy and use and to preserve the forests thereon from destruction.

A later law, approved February 15, 1901 (31 Stat., 790), already quoted on page 139, specifies further powers with reference to national forests. Under an act approved February 1, 1905, the execution of all laws relative to national forests, or forest reserves, as they were known at that time, was transferred to the Secretary of Agriculture, and it is section 5 of that act which, in the opinion of the Department of Justice, confirms the opinion that Congress did, in the previous act above quoted, clothe the Secretary of the Interior with anthority to issue permits and make regulations for the establishment and maintenance of water powers therein. The text of section 5 is as follows:

'That all money received from the sale of any product or the use of any land or resonlee of said forest reserves shall be covered into the Treasury of the United States and, for a period of five years from the passage of this act, shall constitute a special fund available until expended as the Secretary of Agriculture mas direct, for the protection, administration, improvement, and extension of feleral forest reserves.

In response to a request made by the Secretary of the Interior to the Department of Justice for an opinion as to the powers conferred upon said Secretary by the terms of these acts, Attorney-General (now Mr. Justice) Moody rendered the following decision on May 31, 1905 :

Under the act of 1597 you are simply directed to so regulate the occupancs. and use of these reservations as to insure the objects thereof and preserve the forests thepeon from destruction. 'The act contains nothing inconsistent with the making of a reasonable chatre on account of the use of the reserves under the permit granted by you. By the act of 1905 you are to cover into the 'Treasnry money received from the "use of any land ol resonrces" of the reservations, which "shall constitute a special fund *** for the protection, administration, improvenent, and extension of the federal forest reserves." Any sums of money realized in this connection would thus tend to preserve the forests and insure the objects of reservations, and it might therefore be contended that Congress. in authorizing rou to regulate their use and occupation. considered the incidental question of charging for their use a proper subject to be left to your judgment and discretion. That such was the Congressional intent finds support in the fact that services somewhat analogons to compensation have been required for several years without any indication of a disapproval thereof on the part of Congress.

Furthermore, your power to prohibit absolutely the use or occupation of any forest reserve, when such action is deemed by you essential to insure its objects and preserve the forests from destruction, would probably be unquestionable, and that the authority to prohibit carries with it the right to attach conditions to a permission is well established. (22 Opin., 13, 27.)

In answer to your third question, therefore, I have to advise you that, in my opinion, gon are authorized to make a reasonable charge in connection with the 
use and oceupation of these forest reserves, whenever, in your judrment, snch a course seems consistent with insuring the objects of the reservation and the protection of the forests thereon from destruction.

Attorney-General Bonaparte, in a later opinion relative to this matter, under date of October 5,1907 , said:

The question under consideration in that case (l'ofreling to Attomey-General Moody's opinion above quoted) was whether you hal authority to make al reatsonable charge as a condition of a permit under the act aprroved Jime 4. 1 sit (30 Stat., 35), which anthorized the Secretary of the Interior to "make such rules and regulations and establish such service as will insure the objects of such reservations, namely, to regulate their occupancy and use, and to prescreve the forests thereon from destruction."

It will be observed that neither of these nets conferred upon the secretary of the Interior, expressly, any anthority to male a charge of any kind as a condition of granting the permits which they respectively authorized. It was held, howerer, by Attorney-General Moody, that such authority was implied in the power conferred upon the Secretary by the act of 1.897 to srant or refuse the permits, in his discretion, and the act of 1905 was referred to as substantially a legislative recognition of this authority on his part. If, however, the act of 1897 conferred ulon the Secretary of the Interior, and therefore, afterwards, upon the Secretary of Agriculture, the anthority in his discretion to require payment of a reasonable charge as a condition of issuning any such lepmits as are authorized by said act. it seems to me quite clear that the act of 1901, above quoted, convers the like anthority. The language of the later act appears to me more explicit than that of the former, and the intention of the Congress to leave the privileges sranted under that act revocable in the discretion of the secretary, as is expressly stated in the last proviso. above quoted, of the act of 1901. seems to he more nearly consonant with a purpose to intrinst to his discretion all matters connected with the granting of such permits than is any relevant provision to be found in the act of 1897 . I conclude. therefore, that you are authorized by the act of 1901 to make the granting of permits for the purposes contemplated by that act dependent upon the parment. by the persons receiving such permits. of such charges as you may deem reasonable for the purposes contemplated by the law.

Whether charges based upon the three grounds specifically enumerated in your letter requesting an opiniom would or would not be reasonable is not, under the circumstances of this case, a question proper to be determined by this department, but a matter left by the law entirely to yom discrotion. In Riverside Oil Company $v$. Hitchcock $(190 \mathrm{C}$. S., 325), referred to in the opinion of Attorney-General Moody, above quoted, the court siys: "The responsibility" as well as the power rests with the Secretary, nncontrolled by the courts." This would seem to be no less true as to the question presented in the present case.

It may be well for me to say, howerer, that I do not think it clear, as seems to be assumed in some of the papers formarded with sour letter, that no charge can be made for water used by persons to whom permits may be granted under the act approved February 15, 1901. Snch persons, independently of their permits, would have no right or authority to approlniate the waters witlin the forest reserves; at all events, for such a pmpose as the production of electric power. It is true that the Congress and the compts have recounized a right to appropriate water on the public lands moler state laws or local customs, but lands within the forest reserves alde not covered by general statutes referring to the public lands; and the right to use water on streh pe- 
serves an be secured, it would seem, only under the provisions of the act approved June 4. 1897, and of other legislation specifically referring to the reserves, unless, perhaps, such rights existed before the particular reserve in question was created. I do not, however, consider it necessary to express a positive opinion on this subject, since I understand from your letter that you do not intend to consider the ralue of the mere use of the water itself in fixing the compensation to be paid as a condition for permits for its use.

I advise you, therefore, in conclusion that, in my opinion, you lave the right to make what you believe to be a reasonable charge, as condition of issuing permits under the act of Februiry 15, 1901, and that your determination is decisive as to what charge is or is not reasonable for such purpose.

Under the authority of the law construed by the Department of Justice as set forth above, the Forest Service enforces a power agreement upon parties making use of the national forests for the generation or transmission of water porrer or the construction of reservoirs for storage for water-power purposes. The form of the power agreement is as follows:

UNITED STATES DEPARTMEXT OF AGRICITUUR. FOREST SERVICL.

(Name of forest.)

Uses

lower"

(Name of applicant.)

(Use applied for.)

(Date of application.)

Pover allectment.

CLACSE 1. The compans, hereinafter called the permittee, a (orpolation organized and existing under the laws of the State, or Territory, of _-___-_. and having its oftice and principal place of business at _........... in said State, or 'lerritory, hereby applies for permission to oc(upy and use certain lands of the United States and rights of way reserved by tho wnited states within the _..._-_.-- National Forest. Ly constructing, minintaining, and operating thereon, for the purpose in this clause below set fortlı. the following works:

(Cancel such of the three following items $(a),(b),(c)$ as may not be applicable.)

(a) _..._ dam_- approximately _..... feet in height, respectively, and leservoir_-_ to flood approximately _._._. acres, whereof approximately acres are national-forest land.

(b) _._._. comduit__ approximately _.... miles in length, whereof approximately _._._. miles will lie mon national-forest land or land within national forests over which a right of way for ditches or canals, constructed by the anthority of the United States, is reserved by the act of August 30, 1890 (26 stat., :391).

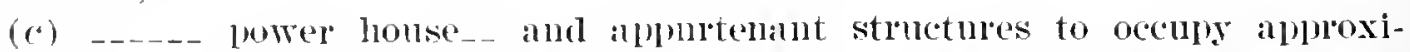
mately _..._. acres. whereof approximately _..._ acres are national-forest land: all alluoximately as shown on _...._ certain tracing_.. executed by

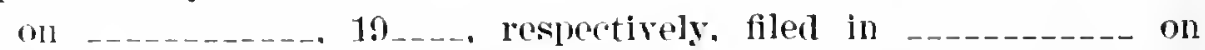
19_._, respectively. and natred by the designation hereto prefixed, which tracing hereby made a lant of this instrument. 
The works for which a permit is hereby applied for are to be constructed, maintained, and operated for the purpose of storing. conducting, and/or using watel for the generation of electric energy.

The permittee does hereby, in consideration for the permit hereby npplied for, promise and agree for itself and its successors to comply with all regulations and instructions of the Department of Agriculture governing national forests, and especially with the following conditions:

Chause 2. The permittee shall pay to the _-_._._._. National Bank of (United States depositury), or such other goverument depositury or officer as shall hereafter be duly designated by the United States, to be placed to the credit of the United States, a construction charge of dollars (\$_..._. ), amnually in advance from _._._._._. until the beginning of the use, for the purpose aforesaid, of the work or works for which permit is hereby applied for, being at the approximate rate of one dollal per acre and five dollars per mile for the land occupied by said works, at which time the permittee shall be entitled to a credit toward the operation charge hereinafter mrovided for of part of such annul construction charge so last paid, proportionate to the remaining part of the year for which such last payment was made; and annually thereafter a net operation charge fixed by the Forester and calculated as follows: The gross operation charge for any year slanll be calculated by the Forester mon the basis of the quantity of electric energy generated in such year at a maximum rate which shall not exceed the following amounts per thousand lilowatt-hours:

Cents

For the fir'st yenr.

second year

third yeal'__....... 6

fourth year

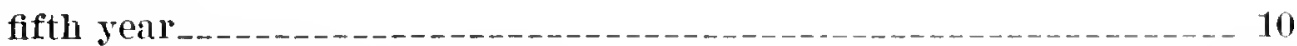

sixth to tenth years, inclusive

eleventh to fifteenth yeal's, inclusive

sixteenth to twentieth years, inclusive $\ldots \ldots \ldots \ldots$

twenty-first to twenty-fifth years, inclusive

twenty-sixth to thirtieth years, inclusive

thirty-first to thirty-fifth year's, inclusive $\ldots \ldots \ldots \ldots \ldots \ldots$

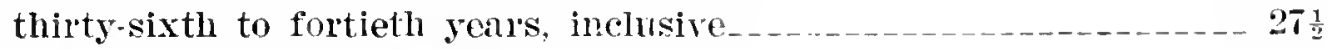

forty-first to forty-iffth years, inclusive

forty-sixth to fiftietl years, inclusive

Clause 3. From the gross operation charge for any vear, calculited as aforesaid, deductions shall be made as follows:

(a) A sum bearing approximately the same ratio to one-half such gross operation charge as the area of umreserved lands and patented lands on the watershed furnishing the water stored, conducted, and/or used in the works for which permit is hereby applied for bears to the total area of the watershed, as of the beginning of each year.

(b) A sum bearing approximately the same ratio to one-half such gross operation charge as the length of the conduit for which permit is hereby aIplied for upon unreserved lands and upon patented lands over which a right of way for ditches and canals is not reserved by the act of Angust 30, 1890 (26 Stat., 391), bears to the total length of such condnit, as of the beginning of each yearr.

(c) A sum bearing approximately the same ratio to the balance remaining after said deductions " $a$ " and " $b$ " as the quantity of electric energy grenerated from water stored artificially by the permittee over and above what is generated by the natural tlow bears to all electric energy generated. 
The sum remaining after all the aforesaid deductions have been made shall be the net operation charge for such year.

Provided, That the term " unreserved lands," as above used in this clause, shall be deemed and taken to mean lands of the United States not reserved as a part of any national forest, and that this permit shall not affect such lands or restrict in any manner the right and duty of the United States to control the oceupancy and use thereof through the department or officer lawfully charged with their custody or control.

Provided further, That the term "patented lands," as above used in this clause, shall include all lands to which title has been perfected in persons, (orporations, States, and Territories; also all lands outside the United States.

Provided further, That the word "conduit," as used in this and other clanses of this permit, shall include ditches, canals, pipe lines, and all other means for the conveyance of a flow of water.

Chause 4. The decision of the Forester shall be final as to all matters of fact upon which the gross operation charge for any sear, the deductions for such year, and the net operation charge for such year depend.

Clause 5. The permittee shall install and maintain in good operating condition, free of any expense to the United States, aceurate meters and other instruments approved by the Forester, adequate for the measurement of the electric energy on which said gross operation eharge is to be calculated, and accurate measuring weirs and other devices approved by the Forester, adequate for the determination of the quantity of watel used in the generation of electric energy from the natural strean flow and, separately, the quantity of water stored by the permittee so used over and above the natural stream flow; and the permittee shinll keep accurate and sufficient records, to the sitisfaction of the Forester and free of any expense to the United States, showing the quintity of electric energy generated in each vear, the quantity of water used in such generation of electric energy from the natural stream flow, and, separately, the quintity of water stored by the permittee so used orer and above the natural stream flow; and the authorized agents of the Forest Service shall. at all times have free access to the aforesaid meters, weirs, instruments, devices, and records of the permittee. In ease the permittee fails for any year to so install and maintain such meters. weirs, instruments, and devices, and to keep such records. the Forester shall fix by estimate the amount of the gross charge and of the deductions for such year, using such information as he can readily obtain.

Chause 6. If the United Stites shall hereafter, for permits of this nature in mational forests, reduce the general scale of maximum rates below those above provided for in clause 2 hereof, or shall wholly abolish charges for permits of this nature, then and theremon the charges to be calenlated and fixed hereunder. as provided in clause 2 hereof, shall be rednced or abolished in like degree.

Clause 7 . 'The permittee shall pay to the United States depositary or officer, as above set forth in clanse 2 hereof, the full value of all merchantable live or dead timber cut, injured, or destrosed in the construction of the said works, title to which, at the time of such cutting, injury. or destruction, is in the United States, according to the scile, count. or estimate of the forest officer in eharge or other duly authorized officer or agent of the United States, such full ralue of timber cut, injured, or destroyed in the construction of said works shall be deened and taken to be, and pasment therefor shall be made in anvance as refuired by such forest oflicer or other duly authorized officer or agent of the 'Lnited states, 
Clause S. The permittee shall dispose of all brush and other refuse resulting from the necessary clearing of or cutting of timber on the lands accupied under the permit hereby applied for as may be required by the forest officer in charge.

Crause 9. The permittee, its employees, contractors, mal employees of contractors shall do all in their power, both independently and npon the request of the forest oflicers, to prevent and smppress forest fires.

Chause 10. The permittee shall, on demand of the district forestel or other duly authorized oflicer or agent of the Lnited States, pay to the Cnited States depositary or officer, as above set forth in clanse 2 hereof, full value as fixed by such district forester or other duly anthorized officer. for all damage to the national forests resulting from the breaking of, or the overllowing, leaking, or seepage of water from the works constructed, mintained, and/or operated under the permit hereby applied for: and for all damage to the national forests callsed by the neglect of the permitter, its employees, contratctors, or employees of contractors.

Clause 11. The permittee shall build new roads and trails as refuired by the forest oflicer or other duly anthorized officer or agrent of the United states to replace any roads or trails destroyed by the constrution work or flooding -under the permit hereby applied for, and to build and maintain suitable crossings as required by the forest officer, or other duly anthorized officer or agent of the United States, for all roads and trails which intersect the conduit, if any, constructed, operated, and/or mantained under the permit hereby apllied for.

Cunuse 12. The permittee shall within _..._- months from the date of aymoval hereof. begin bona fide construction of the works for which pernit is hereby applied for, and shall, within _._._- years from the dite of said approval, complete such construction and begin to operate said works for the purnose in clanse 1 hereof set forth, muless the time is extended by written consent of the Forester; it being understood that such consent will usually be givęn only because of plysicul obstacles to construction, such as floods or engineering difficulties which eould not reasonably have been antieipater.

Clause 13. In constructing any dim or reservir moler the permit hereby "pplied for, the permittee shall follow the usual precantions in the ordinary methods of dam construction. This obligation, however, shill not be enstrued so as to relieve the permittee from any requirement of state liw regarding the construction of dams and storage of water.

Clause 14. The permittee shall sell electric energy to the United States when requested at as low a rate as is given to any other purchaser for a like use at the same time: Provided, 'That the permittee can furnish the same to the United States without diminishing the measured quantity of energy sold before sneh request to any other consmmer by a binding eontract of sile: Provided further, That nothing in this clanse slatl be construed to require the permittee to increase its permanent works or to install additional generating machinery.

Clause 15. 'The permit herely applied for shall be nontransterable (U. $S$. Rev. Stat., sec 3737) and shall be subjeet to all prior valid claims which are not by law subject thereto.

Crause 16. No Member of or Delegate to Congress shall be admitted to any share or part of this agreement or to any benefit to arise thereupon. (U. S. Rev. Stat., secs. 3739 to 3742 , inclusive.)

Cladse 17. No person undergoing a sentence of imprisonment at hard labor imposed by any conrt of the several States, 'Territories, or municipalities having criminal jurisdiction shall be employed in the performance of this contract. (Exeentive order, May 18, 1905.) 
Clause 18. The permittee shall, except when prerented by the act of God or the public enemy or by uniroidable accidents or contingencies, continuously operate for the generation of electric energy the works to be constructed under the permit hereby applied for, in such manner as to generate after such generation begins not less than the following percentages of the full hydraulic capacity of the said works measured in kilowatt-hours: In the first year -..... per cent; in the second year _._._. per cent: in the third yeal _..... per cent; in the fourth year ....... per cent; in the fifth sear ...... per cent; and in every year thereafter -...-- per cent.

Clause 19. If any of the works for which permit is hereby applied for shall be owned, leased. trusteed, possessed, or controlled by any derice permanently, temporarily, directly, indirectly, tacitly, or in any manner whatsoever so that they form part of or in any way effect any combination or are in anywise controlled by any combination, in the form of an unlawful trust, or form the subject of any contract or conspiracy to limit the output of electric energy or in restraint of trade with foreign nations or between two or more States or 'Territories or within any one State or Territory, in the generation, sale, or distribution of electric energy, the permit hereby applied for shall be forfeited to the United States by proceedings instituted by the Attorney-General of the Cnited States in the courts for that purpose.

Clause 20. The prermit hereby applied for shall cease and be void upon the expiration of fifty years from the date of approral hereof, but it may then be renewed in the discretion of the duly authorized officer or agent of the United States and upon such conditions as he mas in his diseretion fix: Provided, That such ofhcer or agent, in fixing such conditions, shall consider the actual value at that time for power and all other purposes of the lands and rights of way within mational forests occupied and used under the permit hereby applied for and the actual value at that time of all improvements lawfulls made by the permittee within national forests under the permit hereby applied for, but neither the property of the permittee, if any, outside of mational forests, nor the permit, franchises, bonds, capital stock, or other securities of the permittee shall be considered in fixing such conditions.

CLAUse 21. Nothing herein contained shall be construed to prevent the Forest Service from having the same jurisdiction orer the lands above specified, including the issuance of further permits, as over other national-forest lands, not inconsistent with the occupation and use hereby applied for.

In witness whereof the permittee has executed this application in duplicate at oll this dily of

[SE.AL.]

$\mathrm{By}$

President.

Attest :

scerctary.

ACKNOWLEDGEMHNT:

STATE of

On this day of $19_{--}$, hefore me, a notary public in and for said county, duly commissioned and sworn. my commission expiring $19_{--,}$personally came to me personally known, who being by me 
duly sworn, did depose and say that he resides in ; that he is the of the Company; that silid eompany is the corporation which is described in and which executed the foregoing instrument; that he knows the senl of said corporation, that the seal affixed to such instrument is such corporate seal, that it was so fixed by order of the board of direetors of said corpol'ation, and that he signed his name thereto by like order; and the said acknowledged sitid instrument to be the free act and deed of said colporation.

Witness my hand and oflicial seal the day and year first above written.

[NOTARIAL SEAL.]

Notary rublic in and for. connty.

Approved $19)_{--}$, and permission granted subject to the conditions set forth.

Forester.

\section{STA'TE LEGISLA'TION.}

Sereral States have begun to realize the necessity for water-power legislation. New York, Pennsylvania, Oregon, and certain other States have laws on this subject, which, so far as they go, are of good purport. Their principal defect is that they do not confer upon the anthorities sufficient initiatory powers. Progress, in these three States especially, may be expected in the near future, but these isolated examples are not sufficient to establish a common policy. This country can not afford to be wise merely in spots. We will review briefly some of the state laws.

\section{PENNSYLVANIA.}

A water-supply commission of five members was created in the State of Pennsylvania under an act approved in May, 1905. This act gave the commissioners authority to collect information relative to the condition of the water supply and provided that no letterspatent should be issued to any company desiring to be incorporated for the purpose of supplying water to the public until the application had first received the indorsement of a majority of the commission.

An act approved in Jume, 1907, increases the scope of the commission's powers by providing that no application for the charter of a corporation for supplying water to the public or for the development of storage or transportation of water power for commercial and manufacturing purposes shall be approved until the same has received the approval of the water-supply commission, or unless such application shall contain the name of the river, stream, or other body of water from which it is proposed to take or use water or water power. The act also provides practically the same requirements in the case of agreements for the merger or consolidation of two or more corporations for the same purposes, and further provides that said cor- 
porations, before merger, shall surrender all the rights theretofore existing to the Commonwealth. There is a further useful requirement that safeguards the stockholders of the companies proposing to consolidate, which provides that no such agreement of merger and consolidation shall be approved by said water-supply commission of Pennsylvania or by the governor until each of the corporations or parties thereto shall have placed in the office of the water-supply commission a written acceptance, under the seal of said corporation and authorized by a majority of the stockholders thereof, both of this act and of the act approved $A$ pril 13, 1905, entitled "An act providing that the right of eminent domain, as respects the appropriation of streams, river's, or waters, or the lands covered thereby, shall not be exercised by water companies incorporated under law," agreeing to be subject to and bound by the provisions of both of said acts, with like effect as if said corporations had bcen formed subsequently to the passage of both of said acts.

Another section of the act provides that no sale, assignment, disposition, or transfer of any franchise of a corporation theretofore or thereafter formed for the supply of water or water power shall be valid until the same has been formally presented to the water-supply commission of Pennsylvania and has received its approval. It is further provided that no corporation for the supply of water or water power. formed or created subsequently to the passage of the act, or subject to its provisions, requiring new or additional source of supply, shall acquire the same until the facts have been placed before the commission, especially the facts concerning the necessity for such new or additional source of supply, and have been approved by the commission and the governor, and a certificate has been issned.

The effect of the Pennsylvania law has been extremely beneficial to the State, and the commission and its agents have been able to collect a large amount of fundamental information that will in the future, as well as in the present, be of immense value to the people. The law now in force is merely a good beginning, and one of its prineipal benefits is to provide publicity of intent upon the part of water-power companies. Under it all the plans and proposals of developnient must be matters of public record, and a great advantage undoubtedly accrues by reason of the anthority of the commission to deny its approval to plans and schemes that do not attain the standards established by the commission. Beyond this, however, the law does not go. It does not give to the commission the power to regulate rates at which power shall be furnished, nor does it establish any standard or classification of powers, such as is attempted under the French proposals. Undoubtedly, this development of the state power of regulation will be a matter of growth, and it is certain 
that in spite of thene onissions of the law, the Commonwealth of Pennsylvania is far in advance of all but a few states of the Tnion in matters of water-supply regulation and the relation thereof to the public.

\section{NEW YORK.}

The State of New look has enacted laws concerning water powers which, while they do not extend in the same direction as those of Pennsylvania, are none the less praiseworthy. In one respect the New York laws are far in advance of any other's in this country, for they recognize and establish the interests of the State in waterpower ownership and development.

The New York water-supply commission was originally constituted to control and regulate the establishment of municipal water supplies by municipal corporations or other civil divisions. The law provides that no such eorporation shall have any power to acquire or take up lands for any new or additional sonrees of municipal water supply until plans, profiles, and specifieations and a statement of needs for such supply shall have been approved by the commission. The law further provides an orderly course of procedure, by which these matters may be equitably adjudicated.

This commission was later given powers previously conveyed to a river-improvement commission, the object of which was to secure and provide means for the regulation of flow of water, the rectification of channels, and the making of reports on the best methods of accomplishing these purposes. This law gave to the commission an indirect relation to the water-power development of the State, but the final law, under which the commission is now ateting. with reference to the development of water power's (chapter 569. laws of 1906) authorizes and directs the commission to devise plans for the progressive development of the water powers of the state. for publir use nuder state ownerstip and control. The law directs that the commission shall proceed to collect information relating to the water powers of the State and shall devise plans for the development of such water powers as it deems available, and may devire plans for the development of such other water powers as shall be brought to its attention by the oflicers of municipalities. It further directs that detailed plans for such development shall be presented in reports made to the governor of the State, and that all other necessary information be furnished to enable the State to establish itself as a developer and owner of water power, for the public bencfit.

The powers of the commission do not extend to the construction of reservoirs and water powers favorably reported on by it, a special act of the legislatme being necessary in each case.

As in Pennsylvania, no power is conferred upon the commission to regulate the sale of water power, nor to control in any way the re- 
lations between the owner of such power and the public which he serves with this utility. An indirect control may in some cases be effected if in the future the legislature shall provide for the construction of the storage works recommended.

The following statement ${ }^{a}$ indicates clearly how the conditions impressed the members of the commission after they had expended a year in study of the subject under the guidance of one of the foremost engineers of the time. So general is the application of this statement that each of the States of the Union would do well to provide that copies of it be widely distributed among its citizens.

There are at this time opportunities for the State to acquire at a minimum cost the necessary lands and rights for the construction of large storage dams for the control of flood waters and for the development of water powers which can be made to yield generous returns to the people, if built, developed, and controlled by the State; but these same lands and rights will in a short time, like our forests, rapidly increase in mice in the hands of private and corporate ownership. These valuable sites, like all natural resonrces. where nature has stored up immense treasure, grow more valuable each year as population becomes denser and the demand for their use increases.

We have only to look across our northern border to the Dominion of Canada to see how our mistakes in allowing prirate interests to acquire natural resources have been aroided by the statesmanship of the Dominion gorernment. Another lesson may be learned from the policy of the Federal Government in obtaining a revenue from the national forests.

\section{OREGON.}

Two laws have recently been enacted by the legislature of Oregon relating to water rights, the beneficial use of water, and the development of water power. The first is an act providing a system for the regulation, control, distribution, use, and right to the use of water and for the determination of existing rights thereto within the State of Oregon, proriding penalties for its riolation, and appropriating money for the maintenance thereof and declaring an emergency. This law went into effect February 24, 1909. The second is an act providing for granting franchises of water power by the State and collecting fees therefor, in effect May 22, 1909.

The first law provides that, subject to existing rights, all waters within the State may be appropriated for beneficial use as provided therein and not otherwise, but nothing therein contained shall be so construed as to take away or impair the vested right of any person, firm, corporation, or association to any water. The State is divided into two water divisions, each under the charge of a superintendent, whose duties are to execute the laws relative to the distribution of water and to perform such other functions as may be assigned to him. He is vested with authority to make reasonable regulations to

a Third Ann. Rept. New York State Water-Supply Commission, 1908, pp. 300-301. 
secure the equal and fair distribution of water in accordance with the determined water rights.

The acts provide for the creation of a board of control, to consist of the state engineer and the superintendents of the two water divisions above mentioned, to which is given supervision of the water's of the State and their appropriation, distribution, and diversion. Appeal from the decision of a superintendent of a water division is made to the board of control, and the decisions of said board are subject to appeal to the circuit and supreme courts of the State.

It is provided that on petition to the board of control, signed by one or more water users upon any stream recuesting the determination of the relative rights of the various claimants to the waters of that stream, it shall be the duty of the board of control, if, upon investigation, it finds the facts and conditions are such as to justify intervention, to make a determination of said rights, and if suit is brought in the circuit court for a determination of rights to the use of water the case may, in the discretion of the court, be transferred to the board of control for determination. The act prescribes an orderly course of procedure in such cases, which inchudes suitable notice of proceedings, statements of claimants, taking of testimony, and all other features necessary to an equitable determination of the facts; provides for the entry of the decision of the board of control in the office of the comnty clerk of each county involved in the decision; and further provides that water-right certificates shall be issued by the board of control to the parties to whom water rights are granted in any case.

The act provides further that water divisions shall be divided by the board of control into water districts, each under the charge of a duly appointed water master, who shall divide the water of the natural. streams and other sources of supply among the sereral ditches and reservoirs according to the rights of each party, and it further vests such water masters with the necessary legal authority and power of arrest.

The procedure prescribed relative to the appropriation of water within the State of Oregon is as follows:

SEc. 45. Application.-Any person, association, or corporation hereafter intending to acquire the right to the beneficial use of any waters shall, before commencing the construction, enlargement, or extension of any ditch, canal, or other distributing or controlling works, or performing any work in connection with said construction, or proposed appropriation, make an application to the state engineer for a permit to make such appropriation. Any person who shall willfully divert or nse water to the detriment of others withont compliance with law shall be deemed guilty of a misdemeanor. 'The possession or use of water, except when a right of use is acquired in accordance with law, shall be prima facie evidence of the guilt of the person using it.

SEc. 46. Applications, nature of.-- Each application for permit to appropriate water shall set forth the nime and post-office address of the applicant. the 
source of water supply, the nature and amount of the proposed use, the location and description of the proposed ditch, canal. or other work, the time within which it is proposed to begin construction, the time required for completion of the construction. and the time for the complete application of the water to the proposed use. If for agricultural purposes, it shall give the legal subdivisions of the land and the acreage to be irrigated, as near as may be. If for power nurposes, it shall give the nature of the works by means of which the power is to be dereloped, the head and amount of water to be utilized, and the uses to which the power is to be applied. If for the construction of a reservoir, it shall give the height of the dam, the capacity of the reservoir, and the uses to be made of the impounded waters. If for municipal water supply, it shall give the present popmlation to be served and, as near as may be, the future requirements of the city. If for mining purposes, it shall give the nature of the mines to be served, the methods of supplying and utilizing the water. All applications shall be accompanied by such maps and drawings, in duplicate. and such other data as may hereafter be preseribed by the board of control, and such accompanying ditil shall be considered as a part of the application.

SEc. 47. Applications. approval of.-Cuon receipt of an application it shall be the duty of the state engineer to make an indorsement thereon of the date of its receipt and to keep a record of the same. If upon examination the application is found to be defective. it shall be returned for correction or completion. and the dite of and rasons for the return thereof shall be indorsed thereon and made a record in his ofhce. No application shall lose its priority of filing on account of such defects, mrovided acceptable maps and drawings are filed in the oflice of the state engineer within thirty days from the date of said return to the applicant. All applications which shall comply with the provisions of this act shall be recorded in a suitable book kept for that purpose, and it shall be the duty of the state engineer to alprove all applications made in mroper form, which contemplate the application of water to a beneficial use, but when the jroposed use conflicts with determined rights, or is a menace to the sifety and welfare of the public, the application shall be referred to the board of control for consideration. It shall be the duty of the board of control to enter an order directing the refusal of such application, if, after full hearing, the public interest demands. In application nay be apploved for a less amount of water than thit alplied for, if there exist substantial reasons therefor. and in aly erent shall not be alproved for more water than can be applied to a beneficial use. Applieations for municipal water supplies may be anproved to the exclusion of all subsequent appropriations, if the exigencies of the case demand. upon consideration and order by the board of control.

SEc. 4S. Applicution, how indorsed.-The approval or rejection of an application shall be indorsed thereon and a record made of such indorsement in the state engineer's office. The application so indorsed shall be returned immediately to the applicant by mail. If approred, the applicant shall be authorized, on receipt thereof. to proced with the construction of the necessary works, and to take all steps required to ajply the water to a beneficial use, and to perfect the proposed appropriation. If the applieation is refused, the applicant shall take no steps toward the construction of the proposed work or the diversion and use of water so long as such refusal shall continue in force.

SEC. 49. Assignment of nermit.-Any permit or license to appropriate water may be assigned, subject to the conditions of the permit, but no such assignment shall be binding except upon the parties hereto, unless filed for record in the office of the state engineer. 


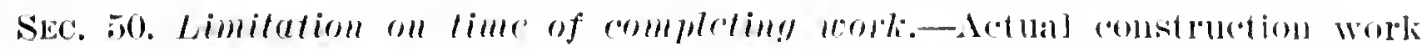
shall begin within one year from the date of approval of the application and the construction of any proposed irrigation or other work shall thereafter be prosecuted with reasonable diligence and be completed within a reasmible time as fixed in the permit, not to exceed five years from the date of such approval. The board of control shall, for good cause shown, extend the tinn within which irrigation or other works shall be completed, or the right perfected under any permit which may be submitted for its consideration by the state engineer.

Skc. 51. Appeuls.-Any applicant may appeal to the board of control for relief, which board may modify the decisions of the stite engineer if it shall appear that he has abused the authority reposed in him by law. Such appeal shall be taken within thirty days from the date of such decision by the state engineer and shall be perfected when the applicant shall have filed in the office of the board a coly of the order appenled from, together with a petition setting forth the appellant's reason for appeal, and such appeal shan be heard and determined upon such competent proofs as shall be adduced by the applicant and such like proofs as slall be adduced by the state engineer. The state engineer shall not sit as a member of the board on such appeal.

SEC. 53. Water-right eertificate.-Upon it being made to appoar to the satisfaction of the board of control that any appropriation has been perfected in accordance with the provisions of this act, it shall be the duty of the board of control to issne to the applicant a certificate of the same character as that described in section 25. Said certificate shall be recorded and transmitted to the applicant, as provided in said section. Certificates issued for rights to the use of water for power development acquired under the provisions of this act shall limit the right or franchise to a period of forty years from date of application, subject to a preference right of renewal under the laws existing at the date of expiration of such franchise or right.

Skc. 54. Date of right.-The right acquired by such appropriation shall date from the filing of the application in the office of the state engineer.

SEc 55. Head-gute, maintenance of.-The owner or owners of any ditch or canal shall maintain, to the satisfaction of the division superintendent of the division in which the irrigation works are located, a substantial head-gate at the point where the water is diverted, which shall be of such construction that it ean be locked and kept closed by the water master; and such owners shall construct and maintain, when required by the division superintendent, suitable neasuring derices at such poiuts along such ditch as may be necessary for the purpose of assisting the water master in determining the amount of water that is to be diverted into said ditch from the stream or taken from it by the various users. Any and every owner or manager of a reservoir located across or upon the bed of a natural stream shall be required to construct and maintain, when required by the division superintendent, a measuring device of a plan to be approved by the state engineer, below such reservoir, and a measuring device above such reservoir on each or every stream or sonrce of supply discharging into such reservoir for the purpose of assisting the water master or superintendent in determining the amount of water to which proprietors are entitled and thereafter diverting it for such appropriator's nse. Whell it mily be necessary for the protection of other water users, the division superintendent mas require flumes to be installed along the line of any ditch. If any such owner or owners of irrigation works shall refuse or neglect to construct and put in such head-gates. flumes, or measuring devices after ten day's notice, the division superintendent may close such ditch, and the same shall not be opened 
or any water diverted frou the source of suply, mnder the penalties prescribed by law for the opening of head-gates lawfully closed, until the requirements of the division superintendent as to such head-gate, flumes, or measuring device have been complied with, and if any owner or manager of a reservoir located across the bed of a natural stream shall neglect or refuse to put in such measuring derice after ten days notice by the division superintendent, such superintendent may open the sluice gate or outlet of such reservoir and the same shall not be closed, under penalties of the law for changing or interfering with headgates, mil the requirements of the division superintendent as to such measuring devices are complied with.

SEc. 65. Thater amurtcnant to land for irrigation purposes. - All water used in this state for irrigation murposes shall remain appurtenant to the land upon which it is used: rrorided. That if for any reason it shonld at any time become impracticable to beneficially or economically use water for the irrigation of any land to which the water is appurtenant, said right may be serered from said land, and simultaneously transferred and become appurtenant to other land, without losing miority of right theretofore established. if such change can be nade withont detriment to existing rights, on the approral of an application of the owner to the board of control. Before the approval of such transfer an inspection shall be made hy the proper division superintendent, who shall submit his report to the board of control, whereupon, by order, the board shall approve or disapmove such transfer and prescribe the conditions therefor. Such order shall be subject to appeal as in this act prorided.

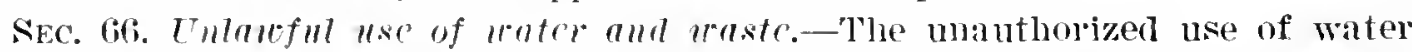
to which another person is entitled or the willful waste of water to the detriment of another shill be a misdemeanor, and the possession or use of such water without legal right sliall be prima facie evidence of the guilt of the person using it. It shill also be a misdemeanor to use, store, or dirert any water until after the issuance of permit to appropriate such witers.

SEc. 67. Obstructiug worlis.-Whenever any appropriator of water has the lawful right of way for the storage. diversion, or carriage of water, it shall be unlawful to place or mantain any obstruction that shall interfere with the nse of the works or prevent comvenient access thereto. Any violation of the provisions of this section shall be a mistlemeanor.

Sec. 70. Tested rights prescred.-1. Nothing in this act contained shall impiar the rested right of any person. association. or corporation to the use of water.

2. Actual application of water to beneficial use prior to the passage of this act by or under authority of any riparian proprietor, or by or under authority of his or its predecessors in interest. shall be deemed to create in such riparian proprietor a rested right to the extent of the actual application to beneficial use, provided such use has not been abandoned for a continuous period of two renrs.

3. And where any riparian proprietor or, under authority of any riparian proprietor $\mathrm{ol}^{\circ}$ his or its predecessor's in interest, any person or corporation shall, at the time this act is filed in the office of the secretary of state, be engaged in good faith in the construction of works for the application of water to a beneficial use, the right to tilie and use snch water shall be deemed vested in such riparian proprietor: Provided. Such works shall be completed and said water deroted to a beneficial use within a reasonable time after the passage of this act. The board of control, in the manner hereinafter provided, shall have power and anthority to determine the time within which such water shall be deroted to a beneficial use. The right to water shall be limited to the 
quantity actunlly applied to a beneficial use within the time so fixed by the board of eontrol.

4. Nor shall anything in this act contained affect relative priorities to the use of water between or among parties to any decree of the courts rendered in causes determined or pending prior to the taking effect of this act.

5. Nor shall the right of any person, association, or corporition, to take and use water be impaired or affected by any of the provisions of this act where appropriations have been initiated prior to the filing of this act in the office of the secretary of state, and such appropriators, their heirs, successors, or assigns, shall, in good faith and in compliance with laws existing at the time of filing this act in the office of the secretary of state, commence the comstruction of works for the applieation of the water so appropriated to a beneficial use, and thereafter prosecute such work diligently and continnously to coml) letion, but all such rights shall be adjudicated in the manner provided in this act.

6. The board of control shall have authority, and shall for good cause, shown upon the application of any appropriator or user of water under an apluropriation of water made prior to the passage of this act, or in the cases mentioned in subdivisions 3 and 5 of this section, where actual construction work has been commenced prior to said time or within the time provided in law existing at the time of filing this act in the office of the secretary of state, to prescribe the time within which the full amount of the water appropriated shall be applied to a beneficial use, and in determining said time shall grant a reasonable time after the construction of the works, or canal, or ditch, nsed for the diversion of the water, and in so doing shall take into consiclerition the cost of the appropriation and application of such water to a beneficial purpose, the good faith of the appropriator, the market for water or power to be supplied, the present demands therefor, and the income or use that may be required to provide fair and reasonable returns upon the investment. Tom making such order the board of control shall direct the state engineer to issue a certificate showing such determination. For good cause shown the board of control may extend the time by granting further certificates.

7. And where appropriations of water heretofore attempted lave been undertaken in good fuith, and the work of construction or improvement theremuler has been in good faith commenced and diligently prosecuted, such appropriations shall not be set aside or avoided, in moceedings under this act, becanse of any ilregularity or insufficiency of the notice by law, or in the manner of posting, recording, or publication thereof.

8. All rights granted or declared by this act shall be adjudicated and determined in the mamer and by the tribmals as provided in this act. This act shall not be held to bestow upon any person, association, or corporation, any riparian rights where no such rights existed prior to the time this act takes effect.

SEc. 72. Eminent domain.-The United States, the State, or any person, foreign or domestic corporation, or association may exercise the right of eminent domain to acquire for a public use any property or rights now or hereafter existing when found necessary for the application of water to beneficial uses, including the right to enlarge existing structures and use the same in common with the former owner. Any right of way so acquired shall be so located as to do the least damage to private or public property, consistent with proper and economical engineering construction. Such property or rights may be acquired in the manner provided by law for the taking of private property for public use. 
The right to conduct water from or over the land of another for any public use. including the right to raise any water by means of dams, reservoirs, or embankments to a sufficient height to make the same available for the use intendefl, and the right to any and all land necessary therefor, may be acquired lipon payment of just compensation in the manner provided by law for the taking of private property for public use.

The law providing for granting franchises of water power in the State of Oregon is as follows: ${ }^{a}$

An act providing for granting franchises of water powor by the state, and collecting fees therefor.

\section{Be it enacted by the people of the state of Oregon:}

SEction 1. All water within the State from all sources of water supply lrekong to the public.

Sic. 2. 'That every person, firm, or corporation, except municipal corporations (hereinater called the appropriator), who shall appropriate water after the bassige of this act for the purpose of applying the same to the derelopment of power shall, during the life of such appropriation as fixed herein, pay to the State of Oregon not less than 2.5 cents or more than $\$ 2$ per anmum in advance, on or before the $2 d$ day of Jamnary of each year, for each and every horse[rower represented by the sitil apropriation. The amount of the payment shal] he determined by the board of control and adjusted from time to time, based npon the percentage of power apmopriated which is put to beneficial use. For the purpose of this act a horsepower is hereby defined to be 550 pounds of water per second of time for each foot of a vailable fall.

sic: 3. The appropriator slall pay to the board of control the fees required by section 2 of this act, proportionate to the remainder of the current year, and no appropriation of water for power purposes shall be deemed complete until such parment of fees is made. Immediately upon the receipt of such fees the board of control shall pay them orer to the state treasmer, taling his receipt therefor, who shall place the same in the general fund of the state treasury. On or before the 2d day of January of each year thereafter every appropriator of witer for lower purposes shall forward to the board of control the fees linovided for in section 2 of this act.

SEc. 4. Cinon the completion of the appropriation of water for power purposes, as now or hereafter provided by law. and compliance with the provisions of this act, the appropliator thereof shall own and enjoy all of the uses thereot so long as he pilys the ammal foes therefor herein required, for a trum not exceeling forty year's from the date of appropriation, and shall have a preference right to reappropriate such water under such conditions as may be prescribed by law at the expiration of such term of years provided all fees have been paid. If any appropriator shall fail to pay any annual fee, or shall fail or refuse to renew the appropriation at its expiration, the state shall Jave a preference lien therefor prior to all other liens or claims, except for taxes, upon the improvements of the appropriator for dereloping and applying such appropriation of water and the real estate upon which the same are located, and upon notice from the board of control the attorney-general shall proceed to foreclose the lien and collect any mpaid fees in the same manner as other liens on real property are foreclosed. and the water shall be again subject to appropriation. 
SEc. 5. Any person, firm, or corporation who believes himself or itself injured in any material right by any decision of the board of control shall have the right of appeal from such decision to the circuit conrt for the county in which the proposed appropriation of water is situated.

SEC. 6. In case the board of control is not created by law with power to supervise the appropriation, distribution, and use of the water of the State, then the duties imposed upon the board of control as prescribed by this act shall devolve upon and be assumed by the state engineer.

Filed in the office of the secretary of state February 24, 1909.

\section{OTHER STATES.}

Several other States of the Union have passed water laws which govern, in greater or less degree, the development of water power. Wyoming was the first State to enact a code of water laws, and $\mathrm{Te}$ braska, Idaho, Utah, Nevada, North and South Dakota, Oklahoma, and New Mexico have laws that differ slightly but have the same purport. It will be imnecessary to review them, because the Oregon law, which is the latest, has already been quoted extensively.

\section{CONCLUSIONS.}

The water powers of this conntry have a higher ultimate significance than is generally conceded to them. They are certain to have a dominating effect upon the material progress and integrity of this Republic. In the Old World it has been decided to be a proper function of the Government to declare water powers of public utility and to place them under appropriate laws, the assmmption being that the public has a dominant interest in the development of this great natural resonrce.

No one can safely predict the final form of laws to be enacted to this end. Whether they will lead to government ownership and control and whether, in this country, the State or the National Government shall control are matters for the future to determine. Our present form of government may prove to be all-sufficient in this respect. At least three European countries have found it necessary to make water power a national matter. This report is not to be considered as a plea for nationalization. The American anthor, at any rate, does not at present support that view, but he is impressed with the fact that necessity, and not legal precedent, must eventually direet the course of procedure. It can hardly be expected that when the necessity arrives it will be readily recognized and accepted. Acceptance will be postponed, at enormous cost, until the people can secure a clear vision above the mist of legal precedents. The great difficulty will not be to regulate water-power development and operation, but to convince the people that such regulation is necessary even though it may involve a change in our laws and our habits of thought. 
The power sites of the West that are still in federal ownership present a suitable opportunity for the initiation of policies similar to those that have been found necessary in older countries. That the President of the United States appreciates this opportunity is indicated by the following extract from a special message on the conserration of natural resources, transmitted to the two Houses of Congress January 14, 1910 :

With respect to the public land which lies along the streams offering opportunity to convert water power into transmissible electricity, another important phase of the public-land question is presented. There are raluable waterpower sites through all the public-land states. The opinion is held that the trinsfer of sovereignty from the Federal Government to the territorial governments as they become states include the water power in the rivers, except so far as that owned by riparian proprietors. I do not think it necessary to go into a discussion of this somewhat mooted question of law. It seems to me suthicient to sily that the man who owns and controls the land along the stream from which the power is to be converted and transmitted owns land which is indispensable to the conversion and use of that power. I can not conceive how the power in streams flowing through public lands can be made arailable at all except by using the land itself as the site for the construction of the plant by which the power is generated and converted and securing a right of way thereover for transmission lines. Under these conditions, if the Government owns the adjacent land-indeed, if the Govermment is the riparian owner-it may control the use of the water power by imposing proper conditions on the disposition of the land necessary in the creation and utilization of the water power.

The development in electrical appliances for the conversion of the water power into electricity to be transmitted long distances has progressed so far that it is no longer problematical, but it is a certain inference that in the future the power of the water falling in the streams to a large extent will take the place of natural fuels. In the disposition of the domain already granted, many water-power sites have come under absolute ownership, and may drift into one ownership, so that all the water power under private ownership shall be a monopoly. If, however, the water-power sites now owned by the Government-and there are enough of them-slanll be disposed of to private bersons for the investment of their capital in such a way as to prevent their union for purposes of monopoly with other water-power sites, and under conditions that slatll limit the right of use to not exceeding fifty years, with proper means for determining a reasonable graduated rental, and with some equitable provision for fixing terms of renewal, it would seem entirely possible to prevent the absorption of these most useful lands by a power monopoly. As long as the Government retains control and can prevent their improper nuion with other plants. competition must be maintained and prices kept reasonable. 


\section{INDEX.}

A

l'age.

Agricultural improvement service, work of. 102-107

Agriculture, rights of ................... 13

utilization of water by............... 103

Sce also Irrigation.

Albuquerque Land Co., Gutierres $v$., case of. 118, 119

Altnow, Williams $v$., case of ............ 117-11s

Anthorizations, definition of ............ $45-46$ Sce also Italy; Permits.

B.

Baudin-Dupuy proposed law, nature of....

Baudin-Millerand proposed law, discussion of. 85-88 text of .......................... 85-92

Beck, Sturr $v$., case of . . . . . . . . . . . . . . . . 122

Beneficial use, doctrine of . . . . . . . . . . . 109,114

Oregon law on ................... 151-152

Berne, Switzerland, concessions in........ . 56-58

Bien, Morris, on fees for dam construction. 132-134

Broder $v$. Natoma Water Co., case of........ 130

C.

California Débris Commission, taxing power and ....................... 134

Carpenter, Farm Investment Co. v., case of.. 118

Coal, cost of, water-power charges based on.. 10

Coal, white, definition of ................ 12

Colorado, Kansas v., case of.......... 122-123, 127

Commerce, control of, by United States Gov-

ernment................... 125-136

Commissions, French, organization of....... 94-96

Competition, foreign, dangers from........ 9-11

Coneessions. See France; Italy; Switzerland.

Consolidation, inevitableness of......... 7,21,158

progress of....................... 21

Consumer, burden on.....................

Corporations, abuses by ............... $5-7$

Costs, basis of .

D.

Dams, construction of, fees for.

law for . ....................... 123-125

State control of . ................. 125-130

government construction of.......... 136-137

Dedication, nature of ................ 111-117

Desert-land act, application of, to lands bor-

dering streams............ 110,120-121

effect of ......................... 108-123

on riparian rights................. 118-119

provisions of....................... 110

Ditches for irrigation, cost of.............. 15,24 cost of, comparlson of pumping cost and. 22-26 experiments in ...................... 14-16

limitations of ....................... 25

Diversion. Sce Stream diversion.

Draining. See Franee.

Durance River, reservoirs on, problems of ... 33-34
F.

Page.

Fconomic conditions, ontline of .......... 16-21

Electric transmission, consequences of.. $7-8,38,158$ early application of ................. 12 encouragement of, in France........... 97-98 laws governing .............. 33, 47-48, 158 Elliot $v$. Fitchburg Railroad Co., case of... 128-129

i.

Factories, regulation of ................ 102

Farm Investment Co. $v$. Carpenter, ease of ... 118

Farmers Loan and Trust Co., Pollock v., case of......................... 131

Fishing, rights of . . . . . . . . . . . . . . 114-115 Fitchburg Railroad Co., Elliot v., case of.. 128-129 loreign competition, dangers from ........ $9-11$ Forest Service regulations, water power control by .................. 139-147 France, authorizations in. See I'ermits.

concessions in ... 43-44,61-63,64-74,82-84,86-91 conservation in ..................... 96 draining in . . . . . . . . . . . . . . 98-99, 103-104 electric transmission in.............. 97 factory regulation in................ 102 farm bnildings in .................. 105-106 governmental control in............. $39-42$ $75-76,77,80,85-89,96$ lrrigation in. .......... 18,22-30,93-94, 100-101 legislation for.............. 26-30,76,81 methods of . . . . . . . . . . . 14-16,25-26 lands in, redistribution of........... 104-105 legislation in.............. 30-31,38-45, 74-92 application of................... 39-40 defects of ...................... $40-42$ reform of...................... 42-45 municipal supplies in............ 97, 101-102 permits in ... . . . 30-31, 43, $63,75-78,79-80,85-89$ public utilities in....... $61-63,74,82-84,85,86$ riparian rights in.................. $37-41$, $43,60-62,66-67,74-75,77-78,81-82,85-89$ power privileges and . . . 38-41, $43,46,60-62$ soil improvement in.................. 106 streams in, classes of......... $60-61,74,78,93$ improvement of ................. 99-100 regulation of............. 63-64, S4-85, 101 subsidies in...................... $90-97$ usages in......................... 60,74-75 water-power development in.......... 9,42 water-power plants in, classes of... $63,68,85,88$ establishment of............ 40-41, 78-79 weather service in .................. 107 See also IIydraulic service; $\Lambda$ gricultural improvement service.

Frei Land Society, Switzerland, recommen-

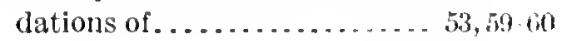


G.

l'age.

Gloucester Ferry Co. $v$. Pennsylvania, case of - 133 Government, authority of. Sc $\ell$ France; Italy; Switzerland; United States.

Gutierres $v$. Athuquerque Land Co., case of. 118-119

$$
\text { H. }
$$

Ilardin $r$. Jordan, case of............... 127

Ilead, value of ......................... 19

IIead Money cases, decision in. .......... 133-134

Ilorsepower, calculation ol............... 18-19

Ilorsepower, storage of, in reservoirs........ 19

IIough, A. C., et al., $v$. Porter, S. A. D., et al., opinion in ................. 109-123

Il ydranlic plants. See Water-power plants.

Ilydraulics and agricultural improvements, bureau of:

organization of .................. $93-96$

work or........................ . 96-107

Hydraulic service, work ol...... . . . . . . . . 96-102

Hydro-electric properties, profits from..... . . 6

\section{I.}

Idaho, water laws in.................. 157

Illumination, power for.................. 20

Indian lands, laws concerning. ........... 114-116

Indians, fishing rights of ............... 114-11i

Industry, power for, demands of........... 20

Irrigation, effect of power diversions on..... 18

encouragement of.................... 93-94

methods of . . . . . . . . . . . . . . 14-16, 25-26 power development and harmonization

of ........................ 26-30

relations of .................. 22-26

Sce also France.

Italy, antimonopoly provisions in......... $50-51$ aut horizations and concessions in...... 45-47, $49-50,51-52$

rentals for, changes in ............ 51 governmental control in.......... 47,49,52 legislation in ..................... 31.45-52 public waters in, classification of......... 45 water-power development in........... 9,42 progress of, conditions of........... 51 regnlation of................... $47-52$ J.

Jenison $v$. Kirk, case of ................ 129-130 Jordan, Jardin $v$, case of............... 127

Jouart, M., proposed law of..............

$$
\mathrm{K} \text {. }
$$

Kansas $v$. Colorado, case of. ......... 122,123,127 Kirk, Jenison $v$., case of .............. 129-130

$$
\text { I. }
$$

Land grants, conditions of. . $111-116$ Leases. Sce Concessions.

Lebrun, Albert, law proposed by. $74-85$

Legislation, remedial, need of . . See also particular counties.

Leighton, M. O., introduction by.

note by........................ 59-60 on water-power legislation in the United States. $108-158$
M.

Page.

Manufacturing, power for, demands of...... 20

Mineral rights, locator o[............... $\quad 113$

Monopoly, charges of .................. $\quad 32$

charges $o$, basls of. .................. 10

creation 0 ......................... $\quad 32$

See also Consolidation.

Municipal supplies. Sre France.

N.

National forests, water powers in, regulation

of..................... 139-147

National laws, discussion of............ 108-147

Natoma Water Co., Broder $r$., ease of....... $\quad 130$

Navigable streams, authority of national goverument over........... 108,132-136

dams on, law on.................. 123-125

water powers on, regulation of........ 123-147

Navigation, meaning of................. 133

Nebraska, water laws of................. 157

Nelson, Knute, on fees for water power dams..................... 125-131

Nevada, water laws in................. 157

New Mexico, water laws in............ 118,157

New York, legislation of ............... 149-150

storage proposed in................. 150

North Dakota, water laws in........... 157

o.

Oklahoma, water laws of.............. 157

Oregon, eminent domain in ............. 156 legislation in ................... 150-157 water-power grants in .......... 150,156-157 water regulation in . ............... 150-150 Sce also Beneficial use.

$P$.

Pennsylvania, Gloucester Ferry Co. v., case of 133 legislation of..................... 147-149 Permits, use of. Sce France; Italy.

Pollock $v$. Farmers Loan \& Trust Co., case of.

Porter, S. A. D., et al., Hugh, A. C., et al., $v$., oplnion in ................ 109-123

President Taft, message of. ............. 10

Prior application, doctrine of . . ........ 108-110,

$118-119,121-123,126-131$

See also Beneficial use.

Public control, basis of . . . . . . . . . ........ 8

Publiclands, authority of Government over 112-116 grants of, subject to prior usage....... 114-116 Public lands, water powers on, laws on... 13i-139 Public use, definition of................ 8

Public utility, laws of................. 9,157

nature of........................ 9,61

See also France.

Public waters, classification of............ 45

Pumping for irrigation, cost of . . . ......... 23 cost ol, comparison of ditch loss and..... 22-24 employment of . ................. 14,24-26 Pyrenees, streams Irom, special problem of. . 33 $\mathrm{R}$.

Railways, water power used by .... 12-13, 48-49,5j Regulation, arguments pro and con......... 32-33 laws for ......................... 30

See also particular countrics. necessity for. 
Reservoirs, storage of, measured in horsepower......................

Rhone River, irrigation from............ 34-35

Rights of way, laws concerning.......... 137-139 Rio Grande Irrigation Co., United States $v$., case of........... 119, 126-127,132-133

Riparian rights, existence and extent of.. 108-111, 118-123, 126-127, 129-130

See also France; United States; Prior application.

\section{S.}

Soil, drainage of $103-104$

improvement of................... 106

South Dakota, water laws of............. 157 Spring, use of ..................... 116-117 States, control of water powers by, argument for and against............. 126-136 water-power jegislation by ........... 147-157 See also particular States.

Streams, classification of 30,60 dams on. See Dams.

diversion of, for power purposes, effect of . . ................. 17-18, 39

flow of, investigation of.............. 26-30 measurement of ................. 26-29 regulation of.................. 101-102 technical expression of............. 28 improvement of . ................ 99-100 See also France.

Sturr $v$. Beck, case of ................... $\quad 122$

Switzeriand, Cantons of, legislation in . 54,55, 58-59 concessions in ............... $56-58,60,86$ governmental control in ............ 52-55,60 legislation in................... $31,52-60$ water-power dcvelopment in ...... 9, 42,58-59

T.

Tavernier, René, on French and foreign water-power legislation........... $37-73$ on hydraulic power and irrigation . . . . . 12-36 paper by

Taxation, powers of national government over................. 130-131,133-135

Thomas $v$. United States, case of.......... 131

$$
\text { U. }
$$

Underground water, pumping of ......... 14 pumplng of, advantages of............ 2t-26 cost of......................... 23-24

United States, water-power legislation in .. 108-158 water development in ............... $35-36$

United States Government, authority of, over streams............ 108-109, 158 authority of, arguments for and against. 123-136
United States Gorcrnment. See also

Navigable streans; Desert-land

law; National laws; State laws.

dams built by ................... 136-137 riparian rights of . ............. 108-109, 158 taxing powers of............. 130-131, 133-135 United States $v$. Rio Grande Irrigation Co., case of.......... 119,126-127, 132-133 United States, Thomas $v_{\text {, }}$, case of......... 131 Use, public, definition of ............... 8 Utah, water laws in.................. 157

\section{IV.}

Water, storage of, benefits of .......... 18-20 utilization of ..................... 103, 126

Water, undergound. See Underground water.

Water powers, comparison of, with transportation.................. 8-9,17 cost of, regulation of . ............. 10 development of ............... 9,42,44 national regulation of . . . . . . . . 123-147 precariousness of ................ 6 investigation of ................. 26-30 leglslation concerning, in national forests...................... 139-147 on public lands............... 137-139 monopoly of...................... 6 riparian rights and .................. 38-41 See also Riparian rights.

sale of, by government.............. 136-137 Water-power plants, classification of, in France................ 63,68,85

consolidation of..................... 7 consequences of ................. 7,21 progress of....................... 21

development of.................. 16-17 irrigatlon and harmonization of..... 26-30 relations of . ............... 22-26 economic conditions governing......... 16-21 establishment of, obstacles to.......... 40-41 horsepower of...................... 18-20 demands on .................... 20 profits from......................... 6 regulation of................... 30-33,157

Water-power policy, nature of........... 157 recommendation for ................ 10,158

Water rights, disputes over.............. 13 intervention of Government in. See France; Italy; Switzerland.

riparian owners and.......... 37-38,41,43,46 Weather protection. Sce France.

White coal, definition of.................. 12

Willams $v$. Altnow, case of ............ 117-118

Wright, C. E., on fees for dam construction. 134-136 Wyoming, water laws in .............118,157 




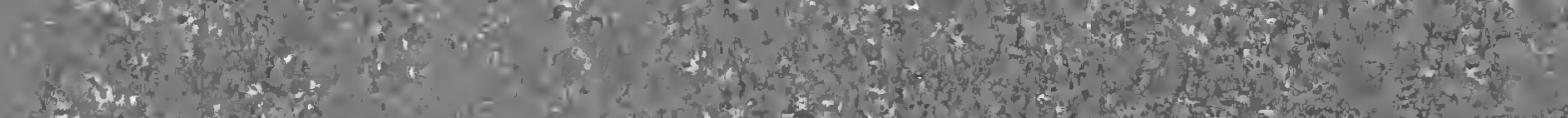
Xetr.

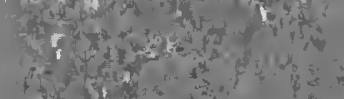
ats

(1) - $x^{2}$

is

in (1) (1)

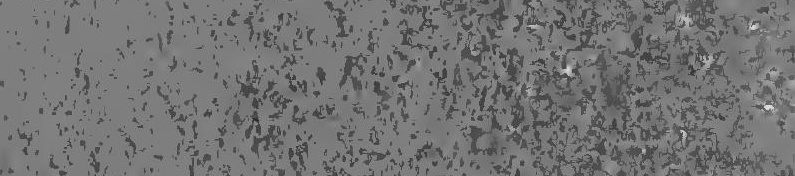

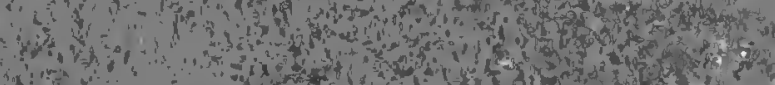

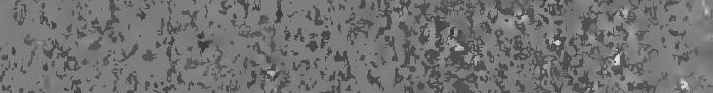

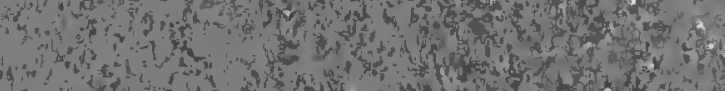
1.

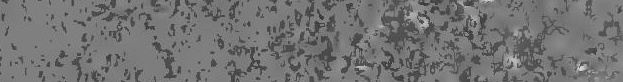

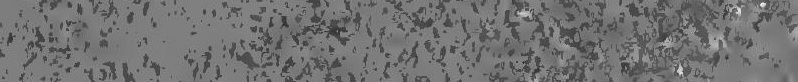
1.

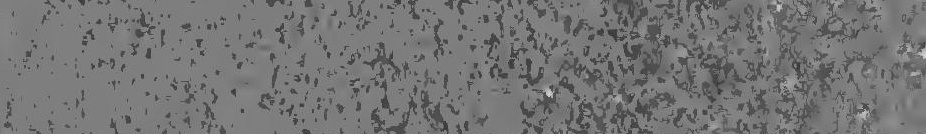

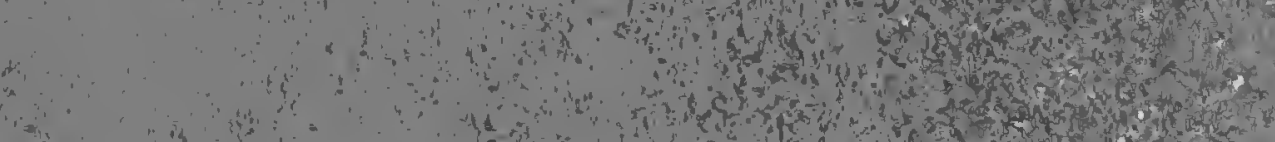

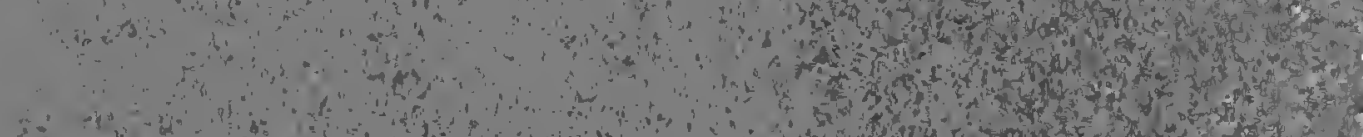

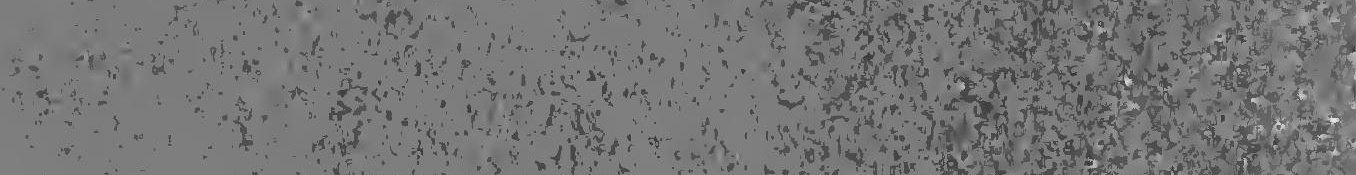

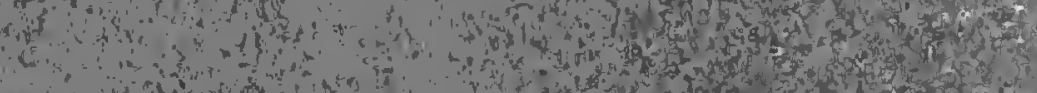

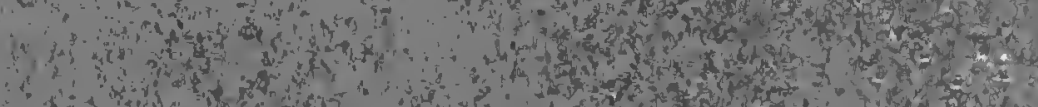

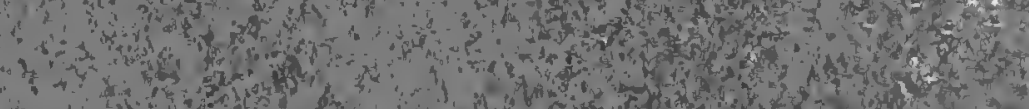

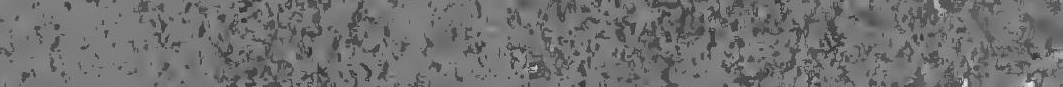

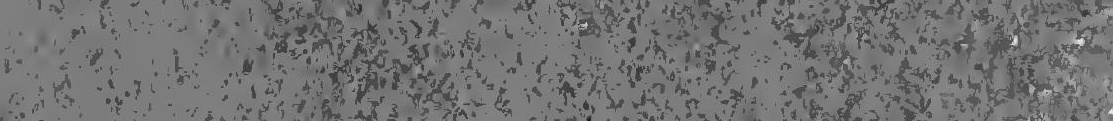

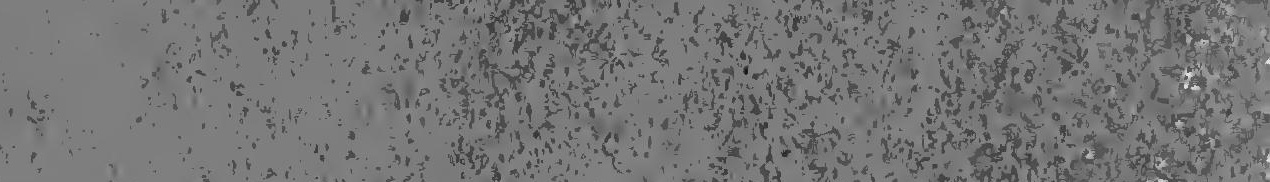

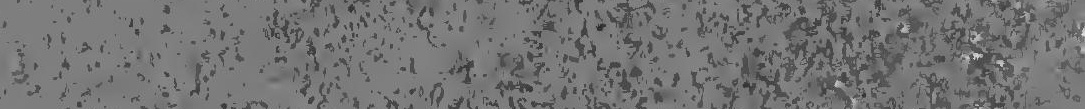

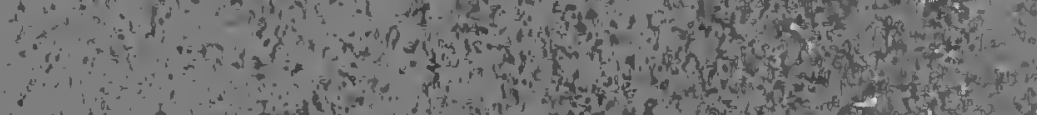

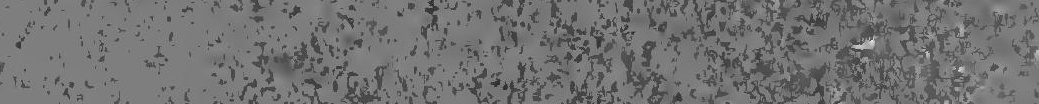

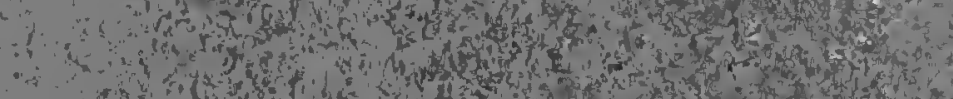

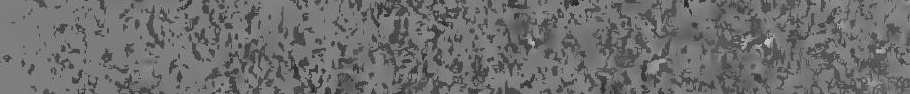

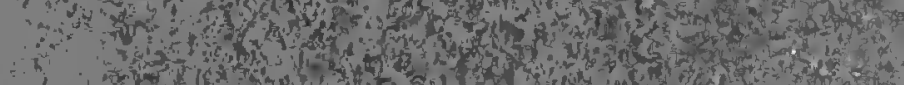

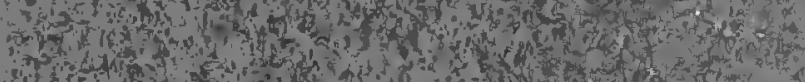

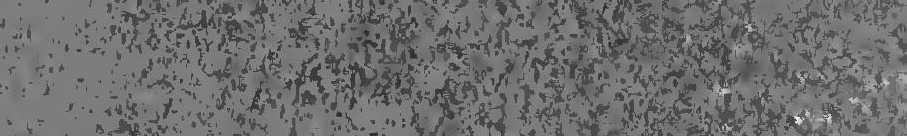

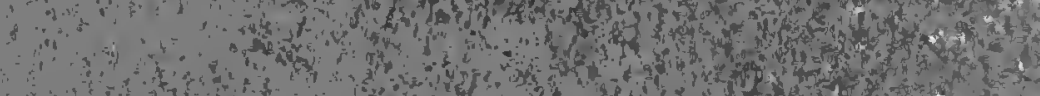

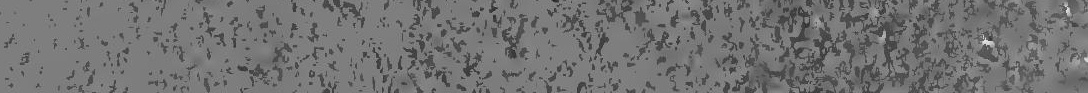

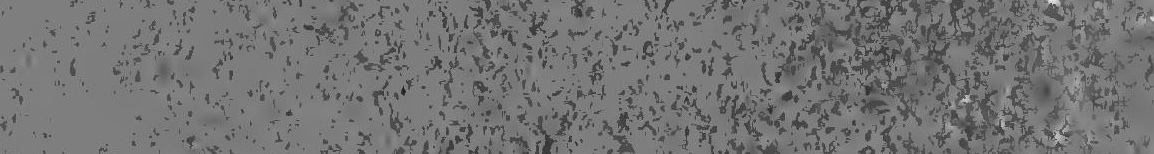

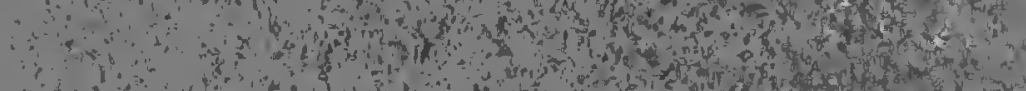

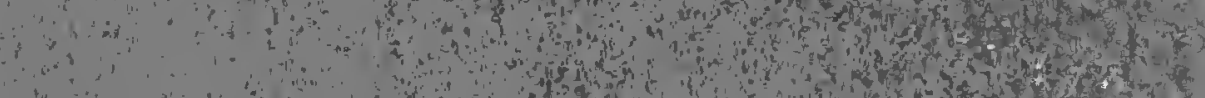



Het-

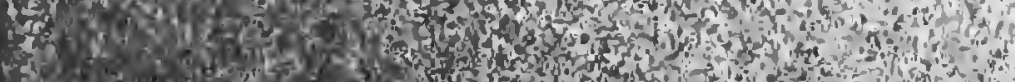

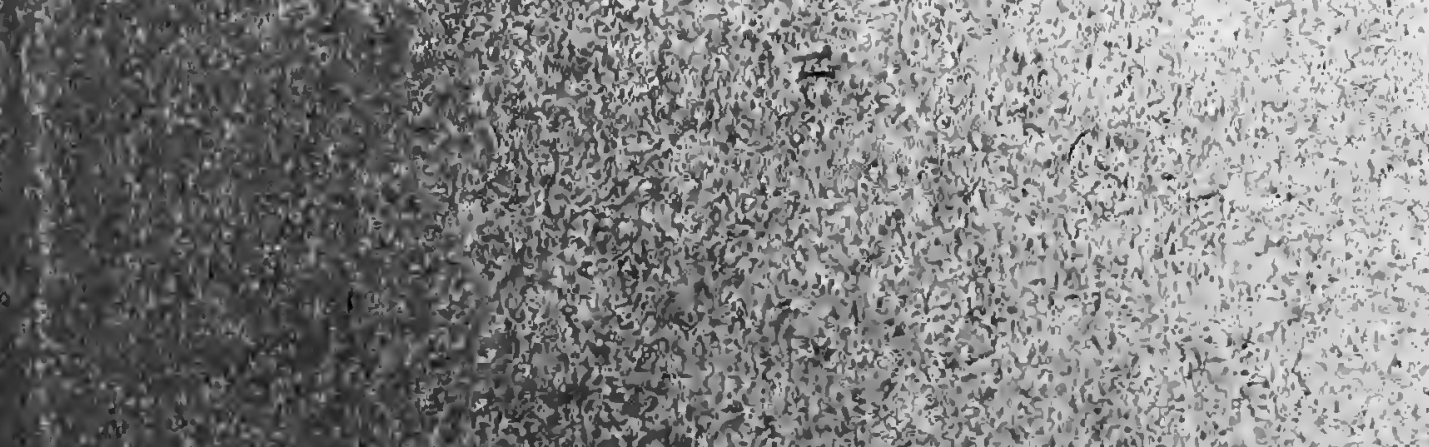

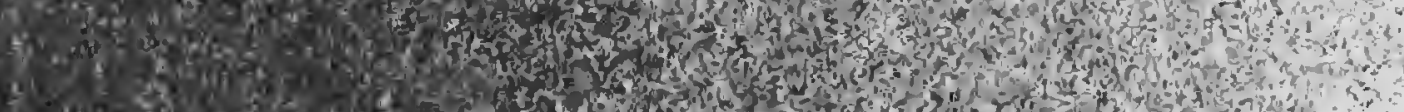

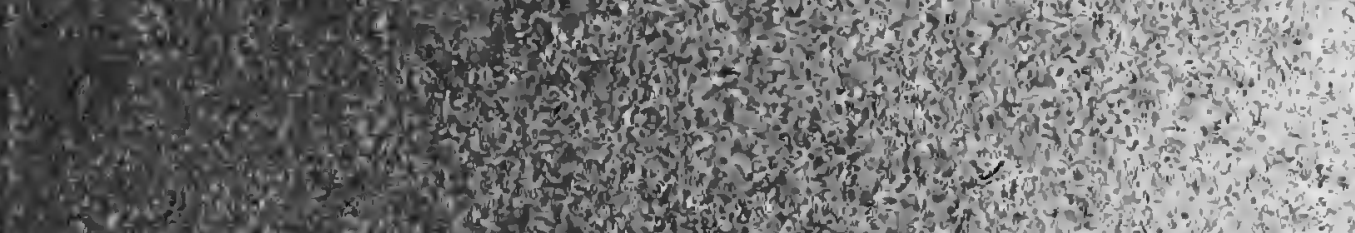

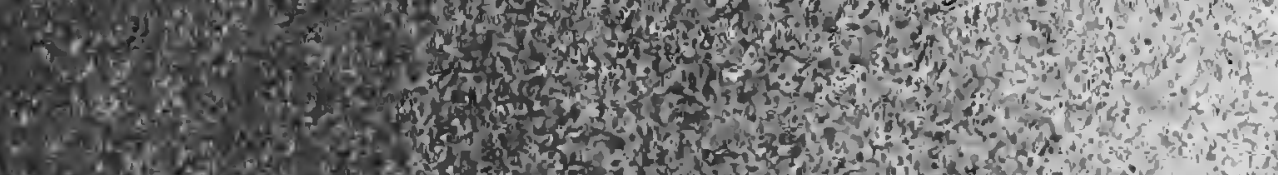

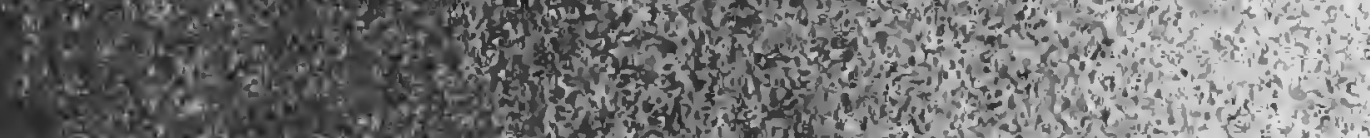

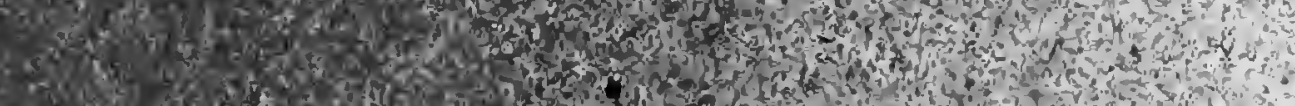

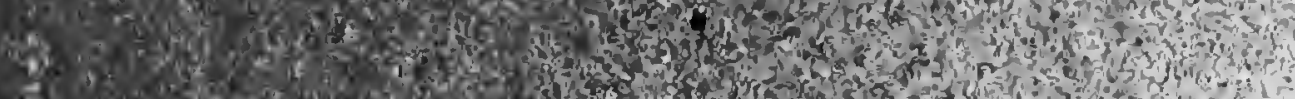

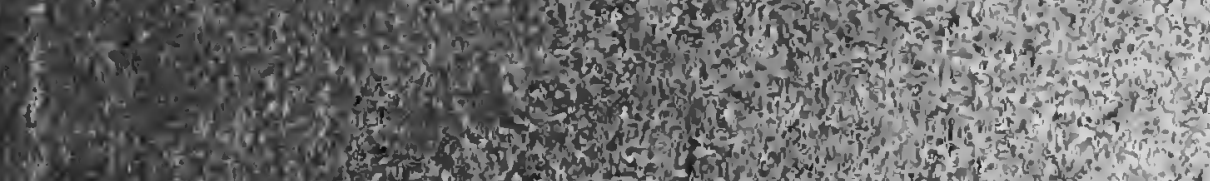

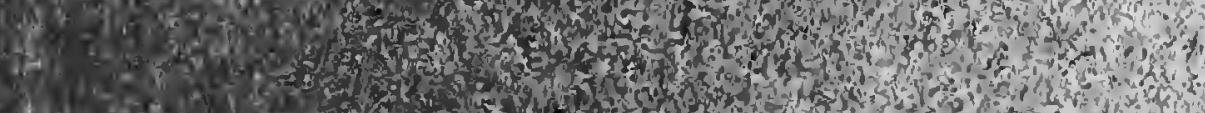
Wo

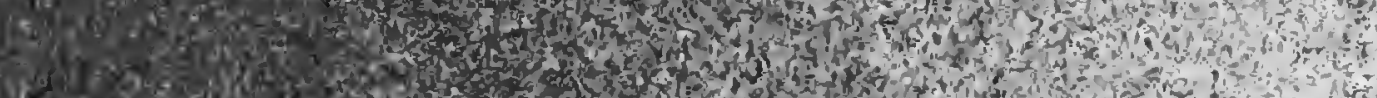

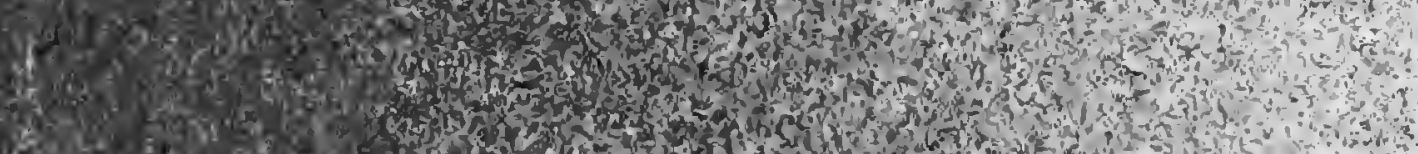

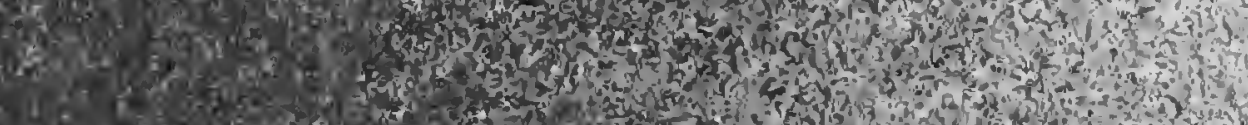

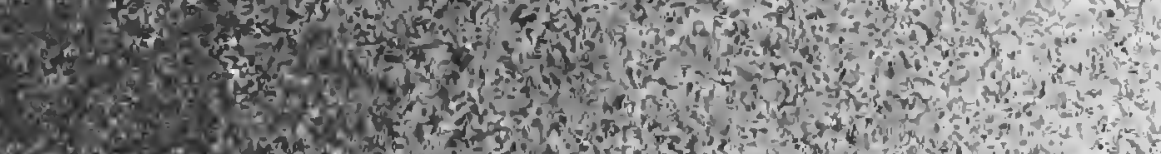

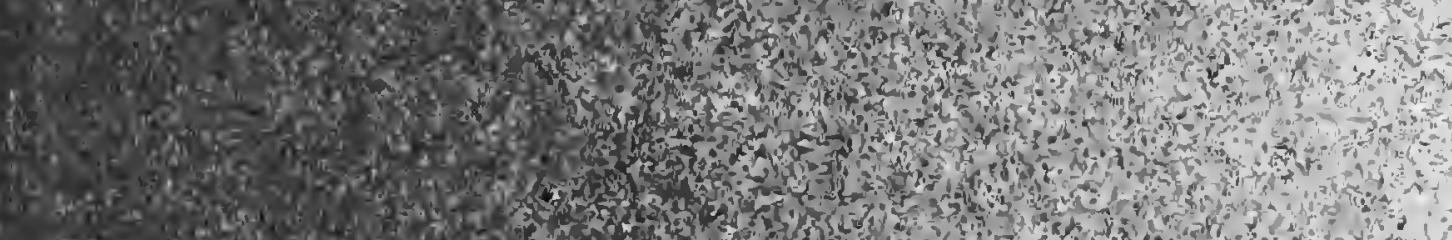

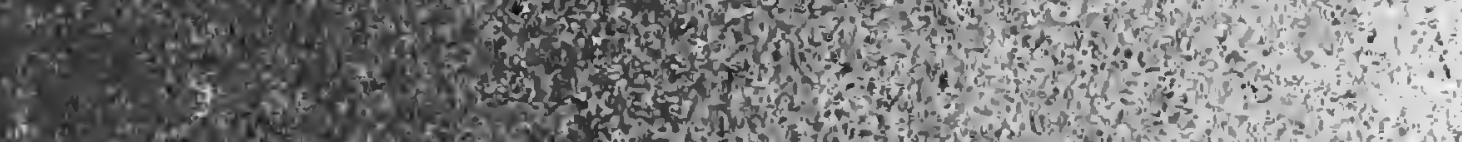

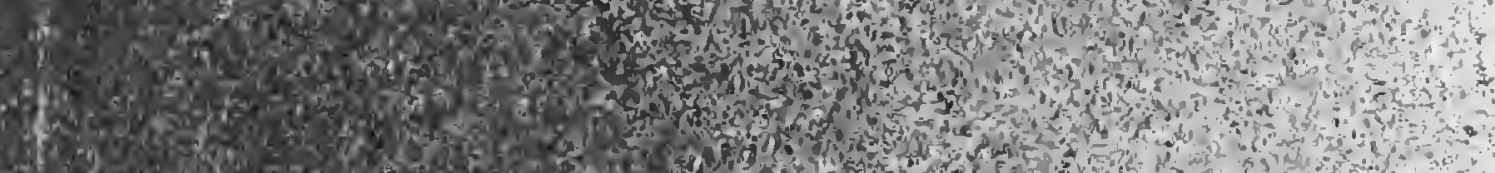
(95)

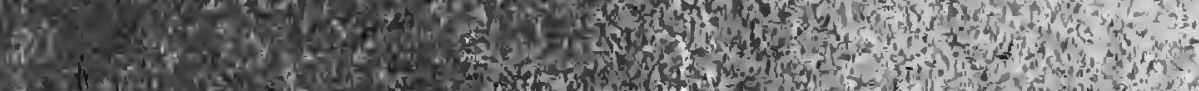

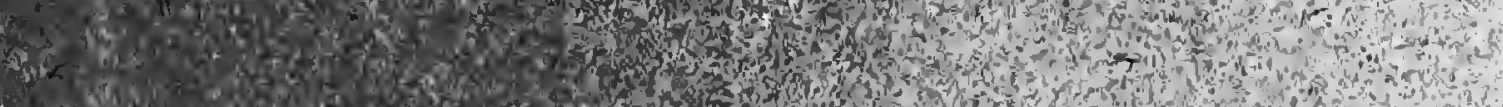
t. 14

yes M.

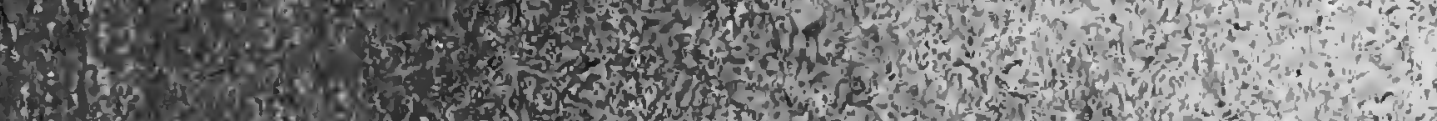

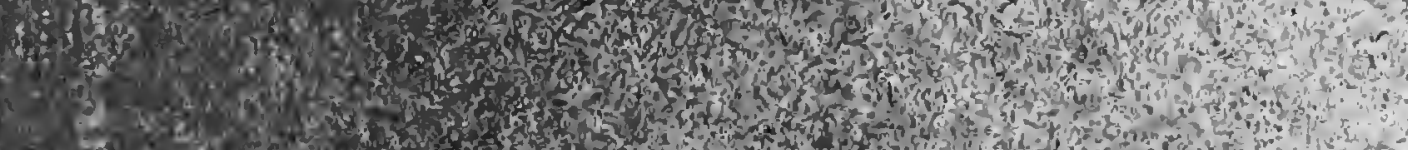

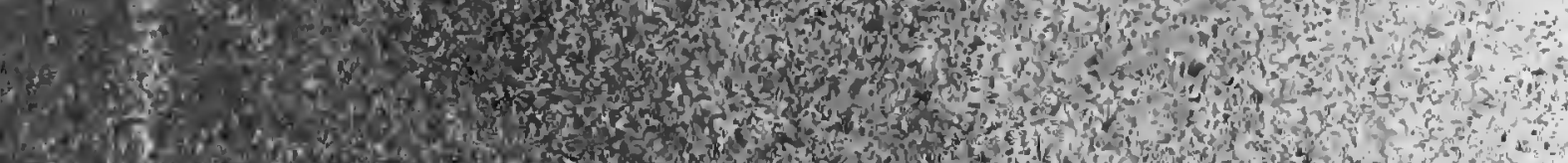


